Prepared in cooperation with the U.S. Department of Agriculture Natural Resources Conservation Service, the Edwards Aquifer Authority, and the Texas Parks and Wildlife Department

\title{
Hydrologic and Water-Quality Data at Government Canyon State Natural Area, Bexar County, Texas, 2002-10
}

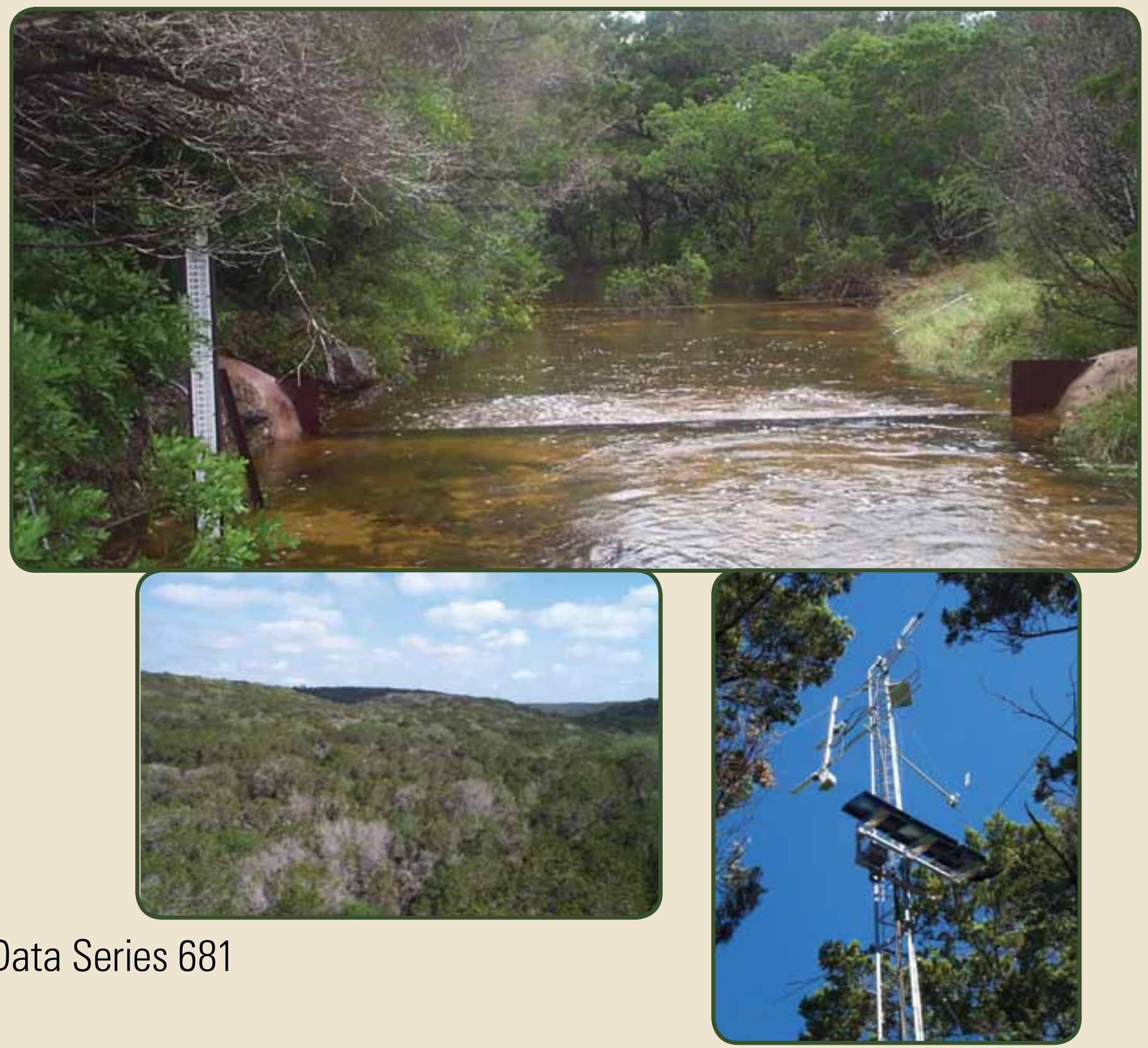




\section{Cover:}

Top, Streamflow channel and weir at U.S. Geological Survey streamflow-gaging station 08180942 Laurel Canyon Creek near Helotes, Texas.

Bottom left, Landscape of Laurel Canyon Creek watershed viewed from the top of the evapotranspiration station.

Bottom right, Evapotranspiration station in the Laurel Canyou Creek watershed at U.S. Geological Survey station 293330098444300 Evapotranspiration Laurel Canyon watershed in the Government Canyon State Natural Area, near Helotes, Texas. 


\section{Hydrologic and Water-Quality Data at Government Canyon State Natural Area, Bexar County, Texas, 2002-10}

By J. Ryan Banta and Richard N. Slattery

Prepared in cooperation with the U.S. Department of Agriculture Natural

Resources Conservation Service, the Edwards Aquifer Authority, and the Texas

Parks and Wildlife Department

Data Series 681 


\title{
U.S. Department of the Interior \\ KEN SALAZAR, Secretary \\ U.S. Geological Survey \\ Marcia K. McNutt, Director
}

\section{U.S. Geological Survey, Reston, Virginia: 2012}

\author{
This and other USGS information products are available at http://store.usgs.gov/ \\ U.S. Geological Survey \\ Box 25286, Denver Federal Center \\ Denver, CO 80225 \\ To learn about the USGS and its information products visit http://www.usgs.gov/ \\ 1-888-ASK-USGS
}

\begin{abstract}
Any use of trade, product, or firm names is for descriptive purposes only and does not imply endorsement by the U.S. Government.

Although this report is in the public domain, permission must be secured from the individual copyright owners to reproduce any copyrighted materials contained within this report.
\end{abstract}

Suggested citation:

Banta, J.R., and Slattery, R.N., 2012, Hydrologic and water-quality data at Government Canyon State Natural Area, Bexar County, Texas, 2002-10: U.S. Geological Survey Data Series 681, 43 p. 


\section{Contents}

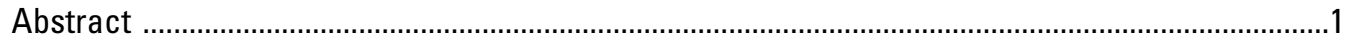

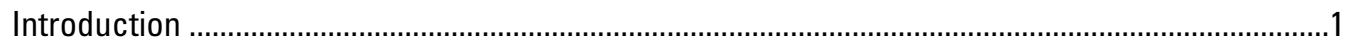

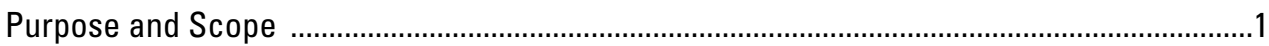

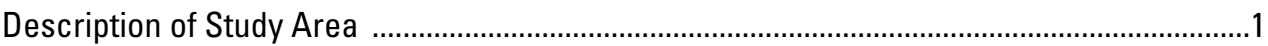

Brush Management Conservation Practices …………….......................................................

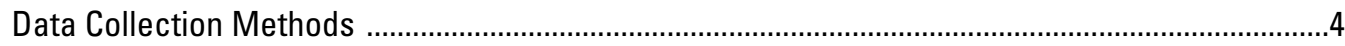

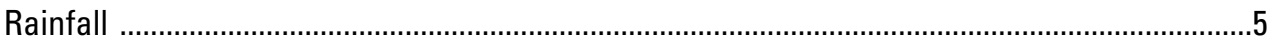

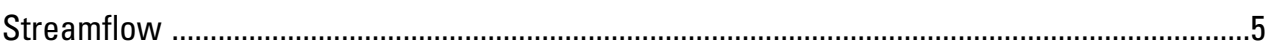

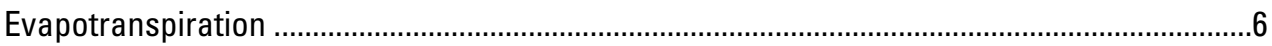

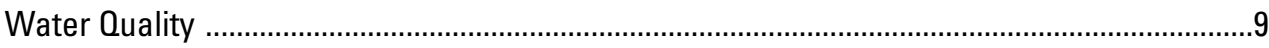

Collection and Processing of Stormflow Water-Quality Samples ...................................

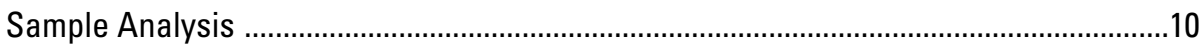

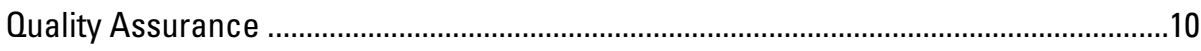

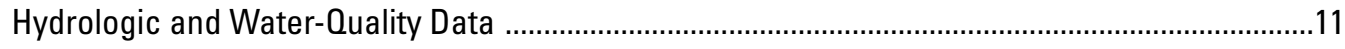

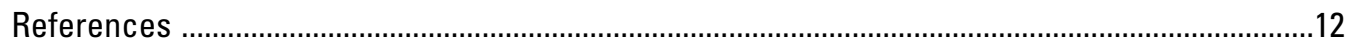

Appendixes

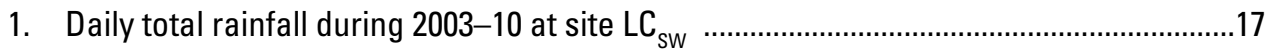

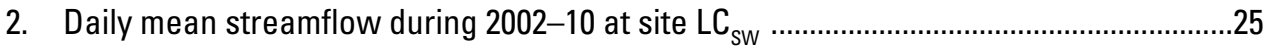

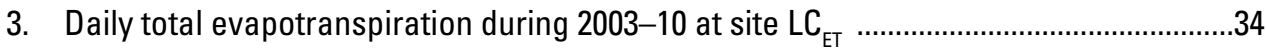

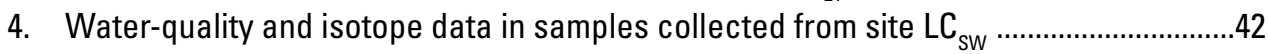

\section{Figures}

1. Map showing location of Government Canyon State Natural Area, Bexar County, Texas

2. Map showing location of data collection sites in the Government Canyon State Natural Area, Bexar County, Texas

3. Photograph of streamflow channel and weir at site $\mathrm{LC}_{\mathrm{SW}}$ (U.S. Geological Survey streamflow-gaging station 08180942 Laurel Canyon Creek near Helotes, Texas), Government Canyon State Natural Area, Bexar County, Tex., on June 29, 2004

4. Photograph of evapotranspiration station in the Laurel Canyon Creek watershed at site $\mathrm{LC}_{\mathrm{ET}}$ (U.S. Geological Survey station 293330098444300 Evapotranspiration Laurel Canyon watershed in the Government Canyon State Natural Area, near Helotes, Texas), Government Canyon State Natural Area, Bexar County, Tex., on October 24, 2007

5. Photographs showing landscape of Laurel Canyon Creek watershed viewed from the top of the evapotranspiration station towards $A$, north, $B$, east, $C$, south, and $D$, west, at site $L C_{\mathrm{ET}}$ (U.S. Geological Survey station 293330098444300 Evapotranspiration Laurel Canyon watershed in the Government Canyon State Natural Area, near Helotes, Texas), Government Canyon State Natural Area, Bexar County, Tex., on April 13, 2011

6. Graph showing evapotranspiration data at site $\mathrm{LC}_{\mathrm{ET}}$ (U.S. Geological station 293330098444300 Evapotranspiration Laurel Canyon watershed in the Government Canyon Station Natural Area, near Helotes, Texas), Government Canyon State Natural Area, Bexar County, Tex. 


\section{Tables}

1. Hydrologic and water-quality data-collection sites in the Government Canyon State Natural Area, Bexar County, Texas

2. Percentage of wind direction by sector at site $\mathrm{LC}_{\mathrm{ET}}$ (U.S. Geological Survey station 293330098444300 Evapotranspiration Laurel Canyon watershed in the Government Canyon State Natural Area, near Helotes, Texas), Government Canyon State Natural Area, Bexar County, Tex., 2004-09

\section{Conversion Factors}

\section{Inch/Pound to SI}

\begin{tabular}{lcl}
\hline \multicolumn{1}{c}{ Multiply } & Bength & \multicolumn{1}{c}{ To obtain } \\
\hline inch (in.) & 25.4 & millimeter $(\mathrm{mm})$ \\
foot (ft) & 0.3048 & meter $(\mathrm{m})$ \\
mile (mi) & 1.609 & kilometer $(\mathrm{km})$ \\
\hline & Area & \\
\hline square foot $\left(\mathrm{ft}^{2}\right)$ & 0.09290 & square meter $\left(\mathrm{m}^{2}\right)$ \\
square mile $\left(\mathrm{mi}^{2}\right)$ & 2.590 & Square kilometer $\left(\mathrm{km}^{2}\right)$ \\
\hline & Flow rate & \\
\hline foot per second $(\mathrm{ft} / \mathrm{s})$ & 0.3048 & meter per second $(\mathrm{m} / \mathrm{s})$ \\
cubic foot per second $\left(\mathrm{ft}^{3} / \mathrm{s}\right)$ & 0.02832 & cubic meter per second $\left(\mathrm{m}^{3} / \mathrm{s}\right)$ \\
\hline inch per year $(\mathrm{in} / \mathrm{yr})$ & 25.4 & millimeter per year $(\mathrm{mm} / \mathrm{yr})$ \\
\hline & Mass & \\
\hline ounce, avoirdupois $(\mathrm{oz})$ & 28.35 & gram $(\mathrm{g})$ \\
\hline & Pressure & \\
\hline atmosphere, standard $(\mathrm{atm})$ & 101.3 & kilopascal $(\mathrm{kPa})$ \\
\hline & Density & kilogram per cubic meter $\left(\mathrm{kg} / \mathrm{m}^{3}\right)$ \\
\hline pound per cubic foot $\left(\mathrm{lb} / \mathrm{ft}^{3}\right)$ & 16.02 & \\
\hline kilowatthour $(\mathrm{kWh})$ & Energy & \\
\hline
\end{tabular}




\section{SI to Inch/Pound}

\begin{tabular}{lll}
\hline \multicolumn{1}{c}{ Multiply } & By & \multicolumn{1}{c}{ To obtain } \\
\hline millimeter $(\mathrm{mm})$ & Length & \\
meter $(\mathrm{m})$ & 0.03937 & inch (in.) \\
kilometer $(\mathrm{km})$ & 3.281 & foot $(\mathrm{ft})$ \\
\hline & 0.6214 & mile $(\mathrm{mi})$ \\
\hline square meter $\left(\mathrm{m}^{2}\right)$ & Area & square foot $\left(\mathrm{ft}^{2}\right)$ \\
square kilometer $\left(\mathrm{km}^{2}\right)$ & 10.76 & square mile $\left(\mathrm{mi}^{2}\right)$ \\
\hline & 0.3861 & \\
\hline meter per second $(\mathrm{m} / \mathrm{s})$ & Flow rate & foot per second $(\mathrm{ft} / \mathrm{s})$ \\
cubic meter per second $\left(\mathrm{m}^{3} / \mathrm{s}\right)$ & 3.281 & cubic foot per second $\left(\mathrm{ft}^{3} / \mathrm{s}\right)$ \\
millimeter per year $(\mathrm{mm} / \mathrm{yr})$ & 35.31 & inch per year $(\mathrm{in} / \mathrm{yr})$ \\
\hline & 0.03937 & \\
\hline gram $(\mathrm{g})$ & Mass & \\
\hline kilopascal $(\mathrm{kPa})$ & 0.03527 & ounce, avoirdupois $(\mathrm{oz})$ \\
\hline kilogram per cubic $\mathrm{meter}\left(\mathrm{kg} / \mathrm{m}^{3}\right)$ & Pressure & atmosphere, $\mathrm{standard}(\mathrm{atm})$ \\
\hline & 0.009869 & pound per cubic foot $\left(\mathrm{lb} / \mathrm{ft}^{3}\right)$ \\
\hline
\end{tabular}

Temperature in degrees Celsius $\left({ }^{\circ} \mathrm{C}\right)$ may be converted to degrees Fahrenheit $\left({ }^{\circ} \mathrm{F}\right)$ as follows:

$$
{ }^{\circ} \mathrm{F}=\left(1.8 \times{ }^{\circ} \mathrm{C}\right)+32
$$

Vertical coordinate information is referenced to the North American Vertical Datum of 1988 (NAVD 88).

Horizontal coordinate information is referenced to the North American Datum of 1983 (NAD 83). Specific conductance is given in microsiemens per centimeter at 25 degrees Celsius $(\mu \mathrm{S} / \mathrm{cm}$ at $\left.25^{\circ} \mathrm{C}\right)$

Concentrations of chemical constituents in water are given either in milligrams per liter ( $\mathrm{mg} / \mathrm{L}$ ) or micrograms per liter $(\mu \mathrm{g} / \mathrm{L})$. 



\title{
Hydrologic and Water Quality Data at Government Canyon State Natural Area, Bexar County, Texas, 2002-10
}

\author{
By J. Ryan Banta and Richard N. Slattery
}

\section{Abstract}

The U.S. Geological Survey, in cooperation with the U.S. Department of Agriculture Natural Resources Conservation Service, the Edwards Aquifer Authority, and the Texas Parks and Wildlife Department, collected rainfall, streamflow, evapotranspiration, and stormflow water-quality data at the Laurel Canyon Creek watershed, within the Government Canyon State Natural Area, Bexar County, Tex. The purpose of the data collection was to support evaluations of the effects of brush management conservation practices on components of the hydrologic budget and water quality. One component of brush management was to take endangered wildlife into consideration, specifically the golden-cheeked warbler (Dendroica chrysoparia). Much of the area that may have been considered for brush management was left intact to protect habitat for the golden-cheeked warbler. The area identified for brush management was approximately 10 percent of the study watershed. The hydrologic data presented here (2002-10) represent preand post-treatment periods, with brush management treatment occurring from winter 2006-07 to spring 2008.

\section{Introduction}

The U.S. Geological Survey (USGS), in cooperation with the U.S. Department of Agriculture Natural Resources Conservation Service, the Edwards Aquifer Authority, and the Texas Parks and Wildlife Department, evaluated the effects of ashe juniper (Juniperus ashei) removal as a brush management conservation practice on the hydrologic budget and water quality in the Laurel Canyon Creek watershed in the Government Canyon State Natural Area in Bexar County, Tex. (figs. 1 and 2). The Government Canyon State Natural Area overlies part of the Edwards aquifer outcrop. Streams originating in the Edwards aquifer catchment area that cross the Edwards aquifer outcrop provide recharge to the Edwards aquifer (Maclay, 1995). The Edwards aquifer is a primary source of water for more than 1.3 million people in the San Antonio, Tex., area.

For locations such as Government Canyon State Natural Area, anecdotal reports from local ranchers, as well as some scientific studies, have indicated that land use and vegetative land cover might have an effect on streamflow, spring discharge, or groundwater recharge (Saleh and others, 2009; Baxter, 2009; Tennesen, 2008; Huang and others, 2006; Thurow and Hester, 1997). Woody vegetation, including ashe juniper, might have encroached upon areas that historically were oak grassland savannahs across much of the Edwards aquifer catchment and outcrop area near the study area. Woody encroachment is generally attributed to overgrazing and fire suppression (Van Auken, 2000; Bray, 1904). By removing the ashe juniper and allowing native grasses to reestablish in the area as a brush management conservation practice (hereinafter referred to as brush management), the hydrology in the watershed might change.

\section{Purpose and Scope}

This report presents hydrologic and water-quality data collected before and after selected brush management conservation practices (ashe juniper removal) within the Laurel Canyon Creek watershed in the Government Canyon State Natural Area, Bexar County, Tex. Hydrologic conditions measured include rainfall, streamflow, and evapotranspiration, as well as selected water-quality physical properties and constituents including $\mathrm{pH}$, specific conductance, selected major ions, and nutrients. The area identified for brush management was confined to approximately 10 percent of the study watershed (Phillip Wright, Natural Resources Conservation Service, written commun., 2011). The data presented here (2002-10) include pre- and post-treatment periods, with brush management treatment beginning in winter 2006-07 and completed in spring 2008. Because of the size of the treated area, the collected hydrologic data were not analyzed for pre- and posttreatment comparisons.

\section{Description of Study Area}

The Laurel Canyon Creek watershed overlies part of the Edwards aquifer outcrop (Stein and Ozuna, 1995) in the Government Canyon State Natural Area northwest of San Antonio, Tex. (figs. 1 and 2). The Laurel Canyon Creek watershed, defined as the drainage area upstream from site $\mathrm{LC}_{\mathrm{SW}}$ (USGS streamflow-gaging station 08180942 Laurel Canyon 


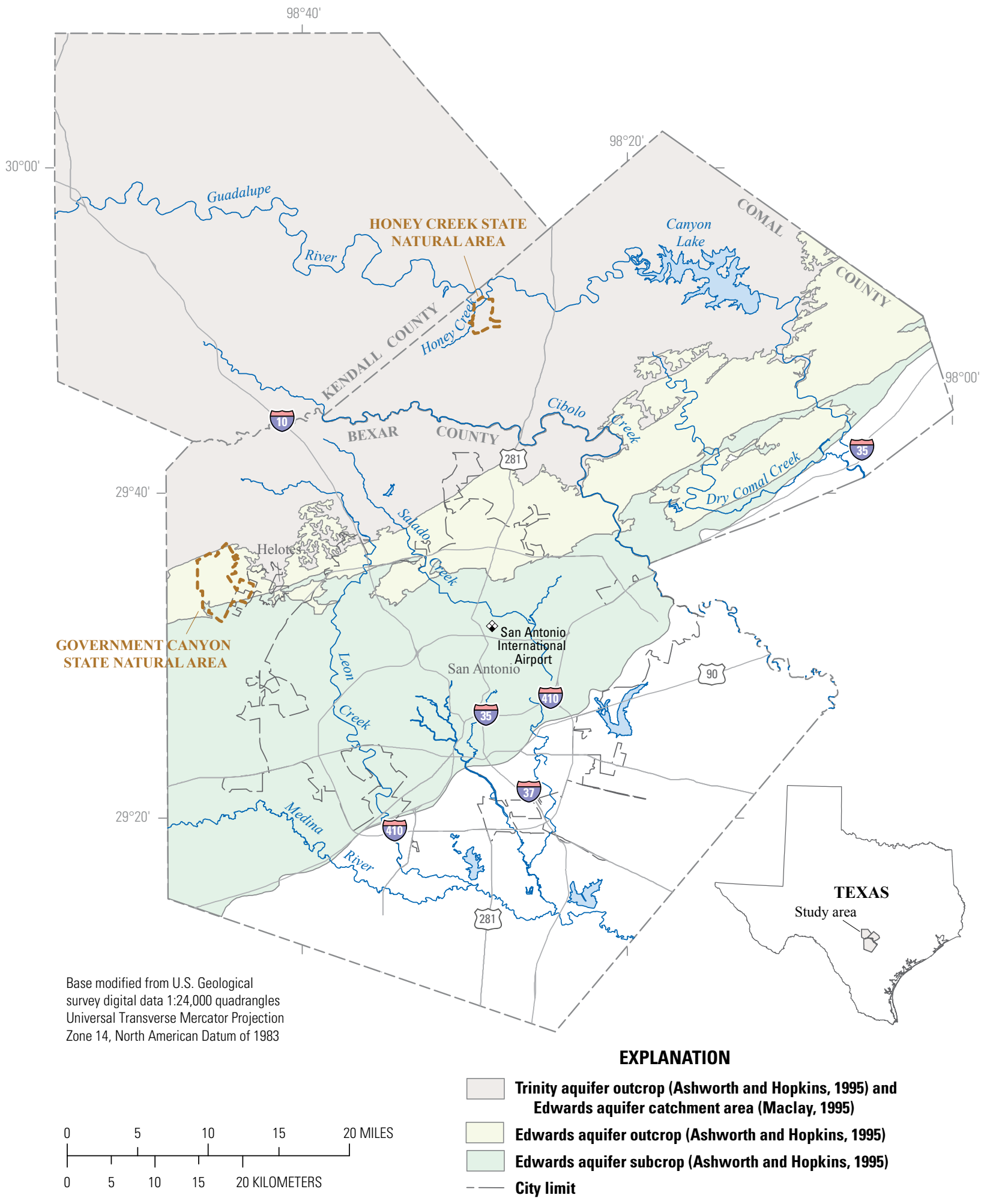

Figure 1. Location of Government Canyon State Natural Area, Bexar County, Texas. 


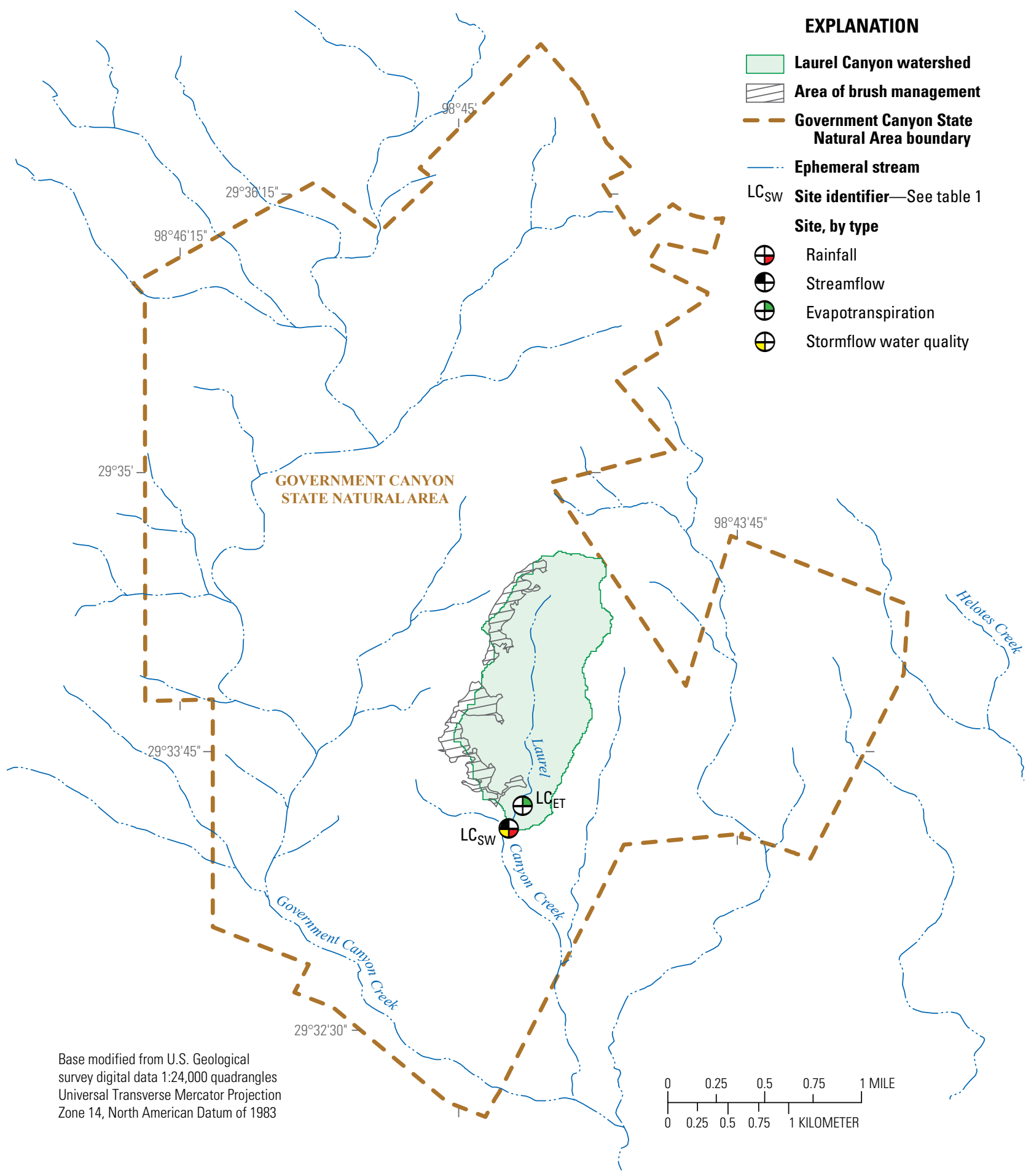

Figure 2. Location of data collection sites in the Government Canyon State Natural Area, Bexar County, Texas. 
Creek near Helotes, Tex.), is 0.61 square mile $\left(\mathrm{mi}^{2}\right)$ in size. Annual rainfall measured at the San Antonio International Airport, Tex. (National Weather Service meteorological station 417945) for the period 1960-2010 averaged 31.6 inches (in.) with interannual variability of 9.3 in. (one standard deviation) (National Climatic Data Center, 2011). Government Canyon State Natural Area is drained by several unnamed ephemeral streams including those referred to locally as Government Canyon Creek and Laurel Canyon Creek (fig. 2). Relief in the watershed is about 300 feet (ft) from the higher elevations to the streamflow-gaging station (North American Vertical Datum, 1988). Woody vegetation covers the majority of the Laurel Canyon Creek watershed and consists primarily of ashe juniper (Juniperus ashei) and live oak (Quercus fusiformis) (Griffith and others, 2007). Other woody vegetation found in the watershed include Texas oak (Quercus Buckleyi), mountain laurel (Sophora secundiflora), cedar elm (Ulmus crassifolia), mesquite (Prosopis glandulosa), and escarpment black cherry (Prunus serotina var. exima) (Griffith and others, 2007). Soils in the watershed are mostly shallow calcareous, stony clay loams (U.S. Department of Agriculture Natural Resources Conservation Service, 2010). Surface geologic formations within the Laurel Canyon Creek watershed include the Edwards formation at higher elevations and the Glen Rose formation at lower elevations (Stein and Ozuna, 1995).

\section{Brush Management Conservation Practices}

Ashe juniper might provide habitat for an endangered species, the golden-cheeked warbler (Texas Parks and Wildlife Department, 2009). To protect habitat for the golden-cheeked warbler, some ashe juniper stands in the Laurel Canyon Creek watershed were identified as "do-not-cut" by Texas Parks and Wildlife Department (Mark Lockwood, Texas Parks and Wildlife Department written commun., 2012). Additionally, a 100-meter (328-ft) do-not-cut buffer was placed around the identified ashe juniper stands. Though ashe juniper historically might have occupied river ravines and steep slopes (Bray, 1904), the protection of ashe juniper in the study area was not restricted to those areas.

Much of the remaining ashe juniper in the study area were removed beginning in the winter of 2006-7 and continuing through the spring of 2008. Removal was done by cutting the ashe juniper near ground level with hydraulic tree shears attached to a skid-steer loader. This method kills the tree with minimal soil disturbance compared to tree dozing. Cut trees were left in place. However, some of the areas selected for brush management were on steeper slopes with limited access, such that it was not possible to clear all of the selected areas. Brush management removed approximately 10 percent $\left(0.06 \mathrm{mi}^{2}\right)$ of the ashe juniper in the Laurel Canyon Creek watershed (Phillip Wright, Natural Resources Conservation Service, written commun., 2011) (fig. 2). Because of the relatively small size of the treated area, the collected hydrologic data are documented in this report but were not analyzed for pre- and post-treatment comparisons.

\section{Data Collection Methods}

The methods used in this study were similar to those described in the Honey Creek watershed study (Banta and Slattery, 2011). The following description of data collection methods is adapted from Banta and Slattery (2011) and reflects site-specific conditions at Government Canyon State Natural Area.

Hydrologic data were collected in the study area during 2002-10 (fig. 2, table 1). Rainfall and streamflow data were collected at USGS streamflow-gaging station 08180942 Laurel Canyon Creek near Helotes, Tex. (hereinafter site $\left.\mathrm{LC}_{\mathrm{SW}}\right)$. Meteorological data used for the calculation of evapotranspiration (ET) were collected at USGS station 293330098444300 Evapotranspiration Laurel Canyon

Table 1. Hydrologic and water-quality data-collection sites in the Government Canyon State Natural Area, Bexar County, Texas.

[USGS, U.S. Geological Survey; dd, degrees; mm, minutes; ss, seconds; NAD 83, North American Datum of 1983; NA, not applicable; RF, continuous rainfall; SW, streamflow; QWS, periodic stormflow water quality; ET, evapotranspiration]

\begin{tabular}{|c|c|c|c|c|c|c|c|}
\hline $\begin{array}{c}\text { Site } \\
\text { identi- } \\
\text { fier } \\
\text { (fig. 2) }\end{array}$ & $\begin{array}{c}\text { USGS } \\
\text { station } \\
\text { number }\end{array}$ & $\begin{array}{c}\text { USGS } \\
\text { station } \\
\text { name }\end{array}$ & $\begin{array}{c}\text { Latitude } \\
\text { (dd mm ss) } \\
\text { (NAD 83) }\end{array}$ & $\begin{array}{c}\text { Longitude } \\
\text { (dd mm ss) } \\
\text { (NAD 83) }\end{array}$ & $\begin{array}{l}\text { Drainage } \\
\text { area } \\
\text { (square } \\
\text { miles) }\end{array}$ & $\begin{array}{l}\text { Type of } \\
\text { data }\end{array}$ & $\begin{array}{l}\text { Period of } \\
\text { record }\end{array}$ \\
\hline \multirow[t]{2}{*}{$\mathrm{LC}_{\mathrm{sW}}$} & \multirow[t]{2}{*}{08180942} & \multirow{2}{*}{$\begin{array}{l}\text { Laurel Canyon Creek near Helotes, } \\
\text { Tex. }\end{array}$} & \multirow[t]{2}{*}{$29^{\circ} 33^{\prime} 24^{\prime \prime}$} & \multirow[t]{2}{*}{$98^{\circ} 44^{\prime} 46^{\prime \prime}$} & \multirow[t]{2}{*}{0.61} & $\mathrm{RF}$ & Nov 2003-Dec 2010 \\
\hline & & & & & & SW & Jun 2002-Dec 2010 \\
\hline
\end{tabular}


watershed in the Government Canyon State Natural Area, near Helotes, Tex. (hereinafter site $\mathrm{LC}_{\mathrm{ET}}$ ). Stormflow water-quality samples were collected at site $\mathrm{LC}_{\mathrm{SW}}$ as composite samples over the duration of selected runoff events (table 1).

\section{Rainfall}

Rainfall data were collected at site $\mathrm{LC}_{\mathrm{SW}}$ using a 12-in. diameter tipping-bucket rain gage (fig. 2) (NovaLynx Corporation, 2001). Measurements were recorded at 5-minute intervals and transmitted every 4 hours by way of the Geostationary Operational Environmental Satellite (GOES) satellite to the USGS National Water Information System (NWIS) database (U.S. Geological Survey, 2011). To maintain the accuracy of the rain gage, the instrument was periodically inspected, cleaned, and calibration checks performed as described by the manufacturer and USGS protocols (NovaLynx Corporation, 2001; U.S. Geological Survey, 2005). If the rain gage did not meet calibration standards (different from expected values by more than 5 percent), it was replaced. If the rain gage was found with debris in the tipping bucket, it was cleaned and the affected data were removed from the NWIS database. Measurements made by the rain gage can also be affected by environmental conditions, which can cause recorded rainfall values to differ from the actual rainfall amounts. These conditions can include high winds and can result in the [under catch] of rainfall (Duchon and Essenberg, 2001). During lowintensity rainfall, the measurement accuracy might be affected by losses to evaporation; during high-intensity rainfall, the accuracy might be affected by the ability of the instrument to register rainfall at the rate of input (Legates and Deliberty, 1993; Duchon and Essenberg, 2001). Other than removing values caused by instrumentation noise (anomalous values not corroborated by preceding and subsequent values), no further corrections were made to the rainfall data. On the basis of field calibration checks, the rainfall data were considered accurate to within 8 percent of actual rainfall. Daily rainfall totals for the period 2003-10 are listed in appendix 1 .

\section{Streamflow}

A streamflow-gaging station (site $\mathrm{LC}_{\mathrm{SW}}$ ) was installed in 2002 at the southern end of the Laurel Canyon Creek watershed study area, upstream from the confluence of Laurel Canyon Creek with Government Canyon Creek (fig. 3, table 1). Streamflow was computed at 5-minute intervals using a theoretical stage-discharge relation (Kennedy, 1983, 1984) and transmitted every 4 hours by way of GEOS satellite to the USGS NWIS database. For verification purposes, recorded stage values were compared to stage values obtained from a reference gage mounted in the stream channel. A crest-stage gage (CSG) mounted in the stream channel was used to mark the peak stage occurring during runoff events and to verify the recorded peaks. The recorded stage was corrected to the reference gage and CSG when the difference was greater than $0.01 \mathrm{ft}$ (Rantz and others, 1982a; Sauer and Turnipseed, 2010).

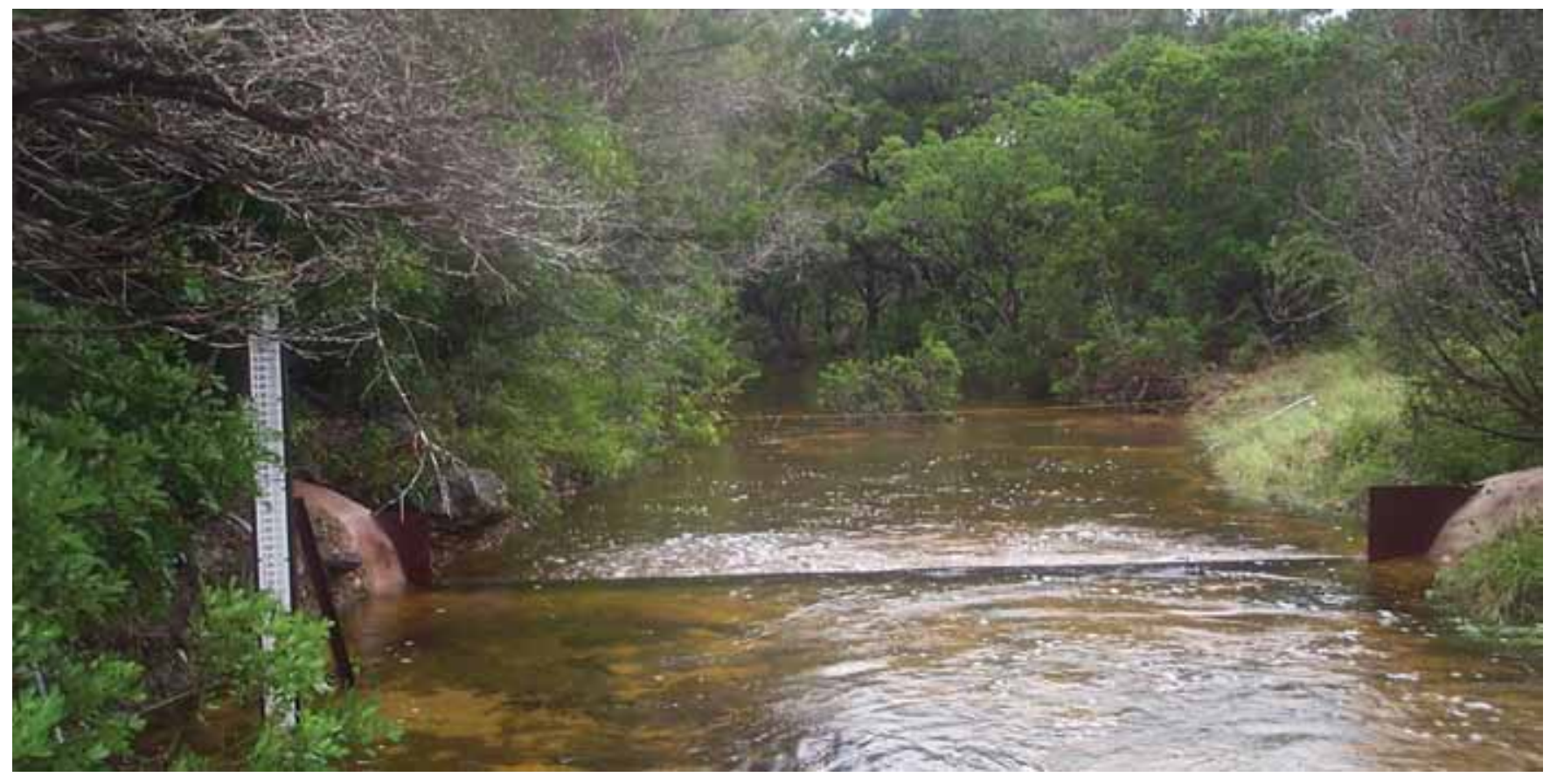

Figure 3. Streamflow channel and weir at site $\mathrm{LC}_{\mathrm{sw}}$ (U.S. Geological Survey streamflow-gaging station 08180942 Laurel Canyon Creek near Helotes, Texas), Government Canyon State Natural Area, Bexar County, Tex., on June 29, 2004. 
A theoretical stage-discharge relation (rating) was developed for the weir and adjustments were made to the rating based on direct measurements of discharge at the site (Kennedy, 1984; Turnipseed and Sauer, 2010). From the stage-discharge relation, the corrected stage data were used to compute discharge. The computed discharges were estimated to be within 8 percent accuracy (Turnipseed and Sauer, 2010). During periods of instrument failure, discharge was estimated by using hydrographic comparisons, interpolation between recorded values, or crest-stage measurements (Rantz and others, 1982b). The rating from the site was applied to calculate discharge for the entire period of record (Bos, 1989; Hulsing, 1967; Rantz and others, 1982b). The daily mean streamflow for each site for the period 2002-10 are listed in appendix 2 .

\section{Evapotranspiration}

Evapotranspiration (ET) refers to the combined processes of evaporation and transpiration. Through these coupled processes, water is converted from a liquid to a vapor and is transferred from Earth's surface to the atmosphere. Sources of water available for evaporation include open bodies of water, soil moisture, and precipitation and water condensate on surfaces. In the process of transpiration, water is transpired by plants, changing from a liquid to a vapor and passing through the stomata (Brustaert, 1982).

The process of evapotranspiration uses energy from the environment, and measuring this transfer of energy is one basis for measuring evapotranspiration (Bowen, 1926). The energy at Earth's surface can be described by the surface energy budget (hereinafter the energy budget). The energy budget balances the incoming and outgoing energy fluxes at Earth's surface and is in equilibrium when all sources of energy in their different states of transformation are taken into account. Assuming that energy fluxes from other sources and sinks are negligible, the simplified form of the energy budget can be expressed as follows (Brutsaert, 1982):

$$
R_{n}-G=H+\lambda E
$$

where

$R_{n} \quad$ is net radiation, the difference between incoming and outgoing radiation, in watts per square meter;

$G$ is soil-heat flux, in watts per square meter;

$H$ is the sensible-heat flux, in watts per square meter; and

$\lambda E$ is the latent-heat flux, energy utilized in the process of evapotranspiration, in watts per square meter.
Evapotranspiration is related to the latent-heat flux $(\lambda E)$ and can be calculated as follows:

$$
E T=1000 * \frac{\lambda E}{\lambda_{v} \rho_{w}},
$$

where

$$
\begin{aligned}
& \text { ET is the rate of evapotranspiration, in } \\
& \text { millimeters per second; } \\
& \lambda E \text { is latent-heat flux, in watts per square meter; } \\
& \lambda_{v} \text { is latent heat of vaporization for water, in } \\
& \text { joules per kilogram; and } \\
& \rho_{\mathrm{w}} \quad \text { is density of water, in kilograms per cubic } \\
& \text { meter. }
\end{aligned}
$$

To calculate ET, the latent-heat flux was estimated using the energy budget Bowen ratio method whereby the latentand sensible-heat are estimated from the Bowen ratio (Bowen, 1926). The Bowen ratio $(\beta)$ is defined as the ratio between $H$ and $\lambda E$, which, assuming equal turbulent bulk-transfer coefficients, also is expressible in terms of vertical gradients of air temperature and air vapor pressure. The equation for $\beta$ thus is:

$$
\beta=\frac{H}{\lambda E}=\gamma \frac{\Delta T}{\Delta e},
$$

where

$\beta \quad$ is the Bowen ratio, dimensionless;

$H$ is the sensible-heat flux, in watts per square meter;

$\lambda E$ is the latent-heat flux, in watts per square meter;

$\gamma \quad$ is the psychrometric constant, in kilopascals per degree Celsius (Radiation and Energy Balance Systems, Inc., 1996);

$\Delta T \quad$ is the difference in air temperature at two different heights, correcting for the adiabatic lapse rate, in degrees Celsius, (Radiation and Energy Balance Systems, Inc., 1996); and

$\Delta e \quad$ is the difference in vapor pressure at two different heights, correcting for the pseudoadiabatic lapse rate, in kilopascals (Radiation and Energy Balance Systems, Inc., 1996).

The Bowen ratio $(\beta)$ is substituted into equation 1 and the latent-heat flux calculated by algebraic rearrangement:

$$
\lambda E=\frac{R_{n}-G}{1+\beta},
$$

where all terms are as previously defined. 
To obtain the meteorological and surface-energy flux data needed for the calculation of ET by the Bowen method, the following manufacturer equipment (and model number where applicable) was installed at site $\mathrm{LC}_{\mathrm{ET}}$ : a Campbell Scientific data logger (CR23X), a Radiation Energy Balance Systems net radiometer (Q7.1), two Radiation Energy Balance Systems temperature and humidity sensors with aspirated radiation shields (THP-1), a Radiation Energy Balance Systems automatic exchange mechanism (AEM), a Met One Instruments wind speed and direction sensor (034B wind sensor), three Radiation Energy Balance Systems soil-heat flux plates (HFT-3.1), Campbell Scientific soil temperature sensors (TCAV), and two Campbell Scientific soil moisture sensors (CS616) (fig. 4).

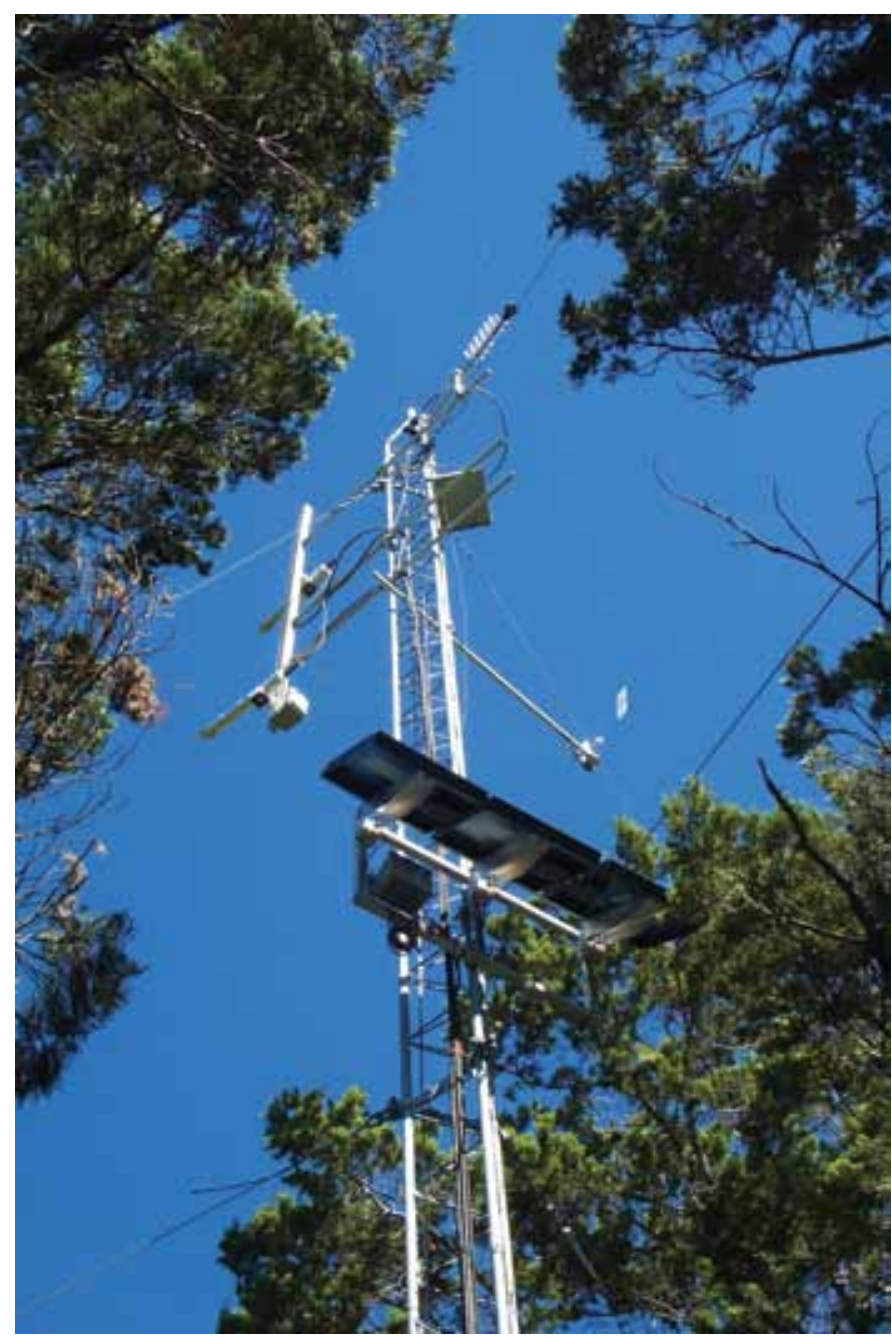

Figure 4. Evapotranspiration station in the Laurel Canyon Creek watershed at site $\mathrm{LC}_{\mathrm{ET}}$ (U.S. Geological Survey station 293330098444300 Evapotranspiration Laurel Canyon watershed in the Government Canyon State Natural Area, near Helotes, Texas), Government Canyon State Natural Area, Bexar County, Tex., on October 24, 2007.
The net radiation, $R_{n}$, is the algebraic sum of all incoming and outgoing longwave and shortwave radiation (Arya, 2001). Measurements of $R_{n}$ were obtained from the net radiometer installed on an evapotranspiration station tower approximately $46 \mathrm{ft}$ above the land surface. The wind sensor was mounted at $37 \mathrm{ft}$ above the land surface. Wind speed was used to calculate a correction coefficient applied to the measurement of $R_{n}$ (Campbell Scientific Inc., 1996).

Soil heat flux, $G$, is estimated from measurements made by the soil heat flux plates, soil temperature probes, and soil moisture probes buried in the area near the tower. Three soil heat flux plates were buried at a depth of 6 in. at various exposures of shade and sun. The soil temperature probes were spaced vertically at about equal intervals in the soil layer above the heat flux plates. Soil moisture probes measure the volumetric water content of the soil. The default calibration of the soil moisture probes was refined using soil moisture data from the Honey Creek State Natural Area study area (Banta and Slattery, 2011), which represent similar soil conditions. Soil cores with a diameter of approximately $0.75 \mathrm{in}$. and length of about 3 to 4 in. were collected using a straight barrel sampler, placed in 4-ounce stainless steel cups, and weighed in the field. The soil cores were then transported to the Texas Water Science Center laboratory, ovendried for 24 hours, reweighed, and soil moisture was calculated (Campbell Scientific Inc., 2004). The change in heat stored in the soil solids and soil water was added to the heat flux measured by the soil heat flux plates to obtain $G$ (Campbell Scientific Inc., 2003).

Temperature and vapor-pressure gradients, $\Delta T$ and $\Delta e$, were calculated from the two temperature and humidity sensors mounted on the AEM. The bottom temperature and vapor-pressure sensors were positioned $36.4 \mathrm{ft}$ above the ground surface and the top sensors were $43.0 \mathrm{ft}$ above ground surface ( $6.6 \mathrm{ft}$ separation between the sensors). The $\Delta T$ and $\Delta e$ values were corrected for the adiabatic lapse rate and pseudoadiabatic lapse rate, respectively, taking into account the 6.6-ft separation in sensor heights (Radiation and Energy Balance Systems, Inc., 1996). The AEM exchanges the position of the sensors every 15 minutes. Averaging the temperature and vapor-pressure gradients over a 30-minute period (where the sensors switch positions at 15-minute intervals) removes possible bias between sensors (Radiation and Energy Balance Systems, Inc., 1996).

To maintain the instruments, site visits were made at 4- to 6-week intervals. During the visits, data were retrieved from the data logger and the instruments were inspected for damage. The net radiometer windshields were inspected and flushed with deionized water to remove dust. The polyethylene windshields of the net radiometers were replaced about every 3 months, or when the windshields were found damaged (for example, by hailstorms or bird pecks). Evapotranspiration was not calculated for periods when the $\mathrm{R}_{n}$ sensor was damaged. The THPs were inspected during visits and washed every 6 months to remove accumulated dust. 
ET-related parameters were measured every 20 seconds, and then 15-minute averages were calculated and recorded by the data logger. A 1-hour running average was applied to the temperature and humidity records prior to calculating ET rates in order to reduce instrument measurement variability and identify the coherent signal in the $\Delta T$ and $\Delta e$ measurements from the sensor (Radiation and Energy Balance Systems, Inc., 1996). The calculated ET rates utilize the two previous 15-minute ET-related parameters (30-minute moving average), reported on a 15-minute interval (Radiation and Energy Balance Systems, Inc., 1996). The calculated ET rates were determined using data from several different instruments and were considered to be accurate to within about 5 percent (Radiation and Energy Balance Systems, Inc., 1996). ET rates were calculated for daytime periods only. The Bowen ratio calculation of ET can be problematic during nighttime because of the required high precision in measurements needed (Jensen and others, 1990). Furthermore, the focus of this study was to evaluate ET rates related to vegetative cover, which are expected to be greatest during daytime hours. Therefore, ET rates were calculated for daytime periods (ET rates were set to zero for non-daytime periods), where daytime was defined as the time between 1 hour after sunrise and 1 hour before sunset.

The calculated ET rates were examined to identify values that were physically implausible or suspected to be erroneous. The ET calculation becomes mathematically unstable as the Bowen ratio $(\beta)$ approaches -1 because it is undefined at -1 . This results in unreasonably large calculated values of $\lambda E$ (equation 4). Consequently, the calculated evapotranspiration rate was rejected when the $\beta$ was within the interval of -1.3 to -0.7. Additionally, following Ohmura (1982), if fluxes of $\Delta e$ and $\Delta T$ were not physically consistent with the calculated sign of available energy, the evapotranspiration rate was rejected. There were periods where the measured parameters passed the aforementioned tests; however, the calculated ET rates were unrealistic and rejected (for example, a negative value). Negative ET rates were not considered physically plausible and were rejected. Additionally, because of instrumentation issues, there were occasional data gaps and the calculated ET rates for the period of missing record were rejected. Rejected ET rates were set to zero. If the calculated ET rates were questionable during a time period of less than 1 hour, and the data on either side of the questionable period were considered acceptable, a linear interpolation was used to fill the data gap.

Daily ET rates were calculated as the sum of the calculated ET rates during daytime periods. Daily ET rates for days where more than 25 percent of the calculated ET rates were rejected are not reported. Daily ET rates at site $\mathrm{LC}_{\mathrm{ET}}$ for the period 2003-10 are listed in appendix 3.

The fetch area is defined as the areal extent that might affect ET measurements (for example, the type of vegetation or presence of an open water body in the fetch area might influence the ET measurements). The fetch area upwind from the sensor can potentially influence the measurement, although as the distance from the sensor increases, its percent contribution to the measurements decreases. That is to say, the farther away from the sensor, the less that area affects the measurement. The fetch area traditionally is approximated as 100 times the vertical height of the temperature-humidity sensor (100:1 fetch-to-height ratio) (Heilman and others, 1989; Burba and Anderson, 2010). However, Heilman and others (1989) demonstrated the fetch-to-height ratio can be as low as 20:1 for Bowen-ratio systems. Stannard (1997) developed a theoretically based determination of fetch requirements for site-specific conditions. The percent equilibrium of the Bowen ratio is calculated as (Stannard, 1997):

$$
\% E q=100 e^{-\left[\ln \left(\frac{z}{z_{0}}\right)-1+\left(\frac{z_{0}}{z}\right)\right] x_{x} k^{2}\left(1-\frac{z_{0}}{z}\right)}
$$

where

$$
\begin{aligned}
\% E q & \text { is the percent equilibration of the Bowen } \\
& \text { ratio, dimensionless; } \\
e & \text { is the base of the natural logarithm; } \\
\ln & \text { is the natural logarithm; } \\
z & \text { is the geometric mean of the sensor heights } \\
& \text { above the zero-plane displacement height, } \\
& \text { in feet; } \\
z_{0} & \text { is the roughness length, in feet; } \\
k & \text { is von Karman's constant, dimensionless; } \\
& \text { and } \\
x_{i} & \text { is the upwind distance, in feet. }
\end{aligned}
$$

The geometric mean of the sensor heights was approximated as the square root of the product of the heights above the zero-plane displacement height, where the zero-plane displacement height was calculated as 0.65 times the canopy height (Campbell, 1972). The roughness length was calculated as 0.13 times the canopy height for dense canopies (Campbell, 1972). A 25 -ft canopy height for mature ashe juniper was used in the fetch calculation (Phillip Wright, Natural Resources Conservation Service, written commun., 2011) (fig. 5). $k$ is von Karman's constant (here as 0.4; Arya, 2001).

The percent equilibration (Stannard, 1997) was calculated for the watershed to account for the area affecting the ET measurements. This was calculated by dividing the 360 -degree radius into 16 equal sectors (for example, 0 degrees for north, 22.5 degrees for north-northeast, 45 degrees for northeast). The distance from the evapotranspiration station to the edge of the watershed was measured for each of the 16 sectors. These distances were input into equation 5 as $x_{i}$, and the percent equilibration was calculated. The percentage of time that the winds were coming from a given sector during daytime hours (WRPLOT View, 2010; table 2) were multiplied by the percent equilibration. These weighted percent equilibriums for each sector were summed to determine the total percent equilibrium. ET rates during periods of light variable winds (less than $1.6 \mathrm{ft} / \mathrm{s}[0.5 \mathrm{~m} / \mathrm{s}]$ ) were assumed to be representative of their respective watershed. This results in the percent equilibration that is contained within the respective watershed. 


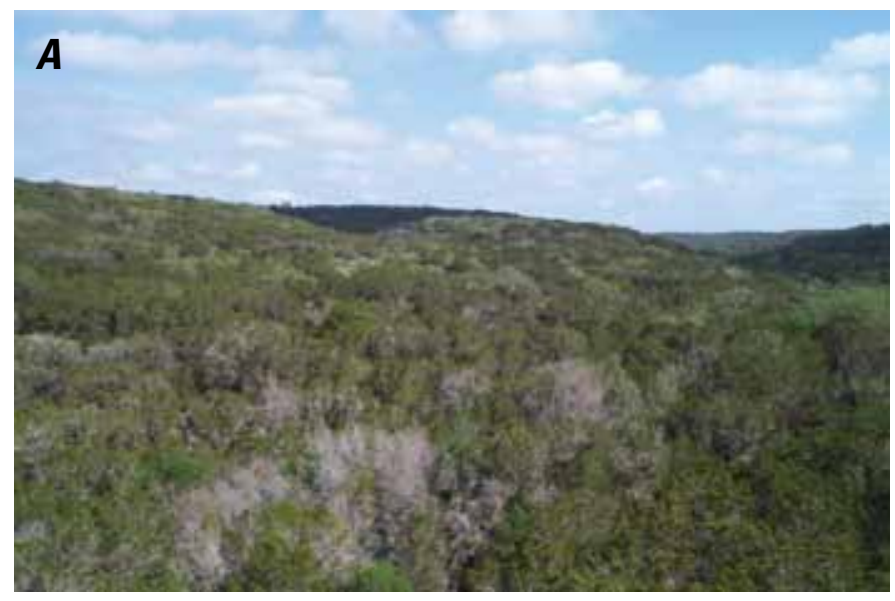

B
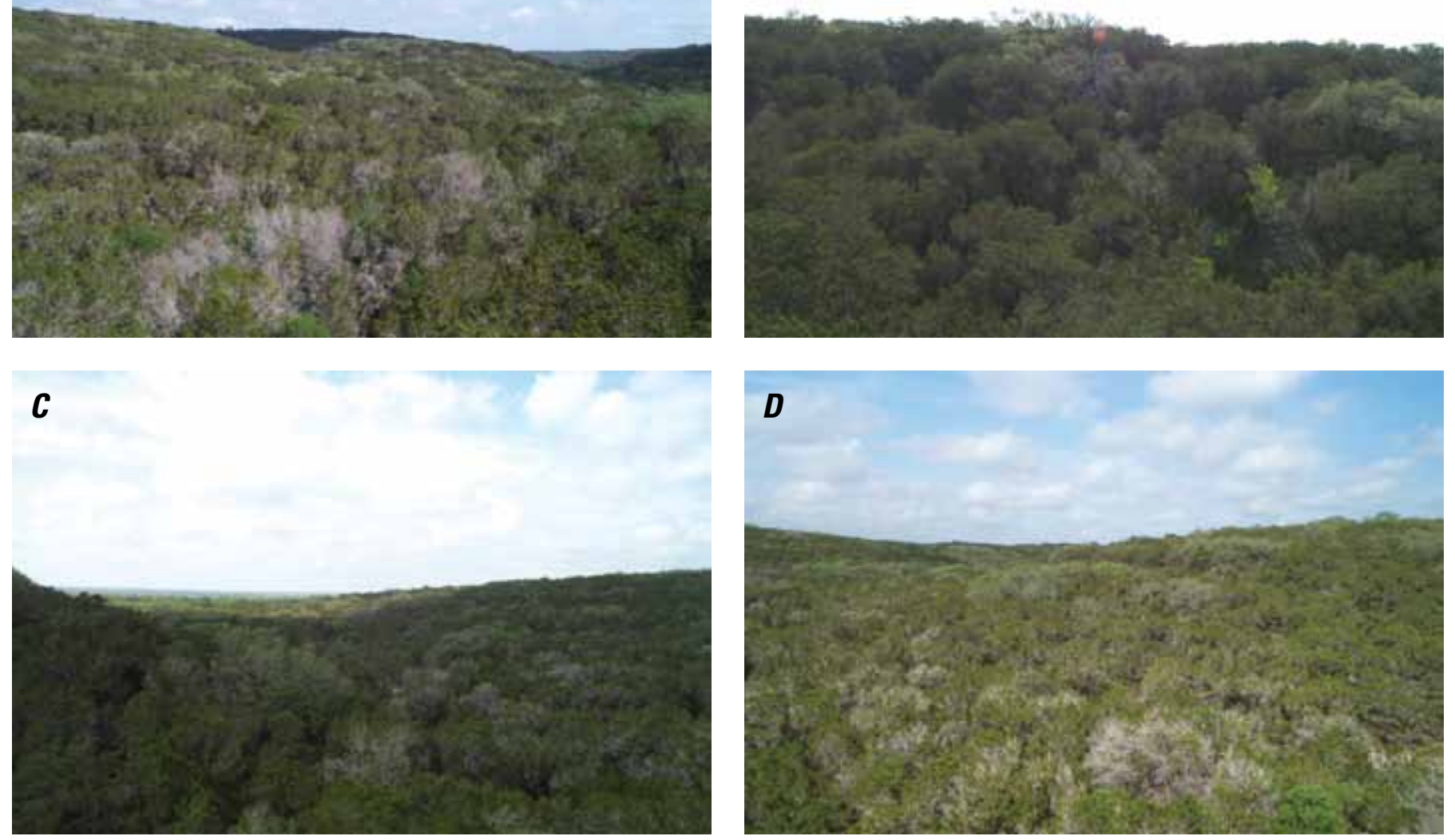

Figure 5. Landscape of Laurel Canyon Creek watershed viewed from the top of the evapotranspiration station towards $A$, north, $B$, east, $C$, south, and $D$, west, at site $\mathrm{LC}_{\mathrm{ET}}$ (U.S. Geological Survey station 293330098444300 Evapotranspiration Laurel Canyon watershed in the Government Canyon State Natural Area, near Helotes, Texas), Government Canyon State Natural Area, Bexar County, Tex., on April 13, 2011.

Given that the vegetation types are potentially similar beyond the watershed boundary (for example, dense ashe juniper vegetation is present in areas surrounding the watershed), the $x_{i}$ distances were adjusted to extend to an edge of similar vegetation representative of the watershed (fig. 5). Specifically, the distances to the south $(2,100 \mathrm{ft})$, south-southwest $(2,300 \mathrm{ft})$, and south-southeast $(2,300 \mathrm{ft})$ were extended. These distances are approximately coincident with the nearest cleared area. The watershed boundary distances are considered conservative values of potential upwind distances as dense stands of ashe juniper also cover most of the land surface in neighboring watersheds. Using the updated distances, the percent equilibration was 90 percent. This indicates that the fetch is largely representative of the Laurel Canyon Creek watershed.

\section{Water Quality}

\section{Collection and Processing of Stormflow Water- Quality Samples}

Stormflow samples collected at site $\mathrm{LC}_{\mathrm{SW}}$ (fig. 1, table 1) were analyzed for selected physical properties ( $\mathrm{pH}$ and specific conductance), major ions, nutrients, total organic carbon, the isotope ratios for hydrogen (deuterium/protium $[\delta \mathrm{D}]$ ) and for oxygen (oxygen-18/oxygen-16[ $\left.\mathrm{d}^{18} \mathrm{O}\right]$ ). Sample preparation, collection, and processing techniques followed standard USGS protocols (U.S. Geological Survey, variously dated).

Stormflow water-quality samples were collected during selected stormflow events using an automatic pumping 
Table 2. Percentage of wind direction by sector at site $\mathrm{LC}_{E T}$ (U.S. Geological Survey station 293330098444300 Evapotranspiration Laurel Canyon watershed in the Government Canyon State Natural Area, near Helotes, Texas), Government Canyon State Natural Area, Bexar County, Tex., 2004-09.

\begin{tabular}{cc}
$\begin{array}{c}\text { Sector } \\
\text { (degrees from north) }\end{array}$ & $\begin{array}{c}\text { Percentage of wind } \\
\text { direction by sector }\end{array}$ \\
\hline 0 & 9.4 \\
22.5 & 4.9 \\
45.0 & 2.7 \\
67.5 & 1.0 \\
90.0 & 1.1 \\
112.5 & 1.4 \\
135.0 & 3.6 \\
157.5 & 20.1 \\
180.0 & 21.5 \\
202.5 & 11.7 \\
225.0 & 4.2 \\
247.5 & 1.2 \\
270.0 & 1.0 \\
292.5 & 1.6 \\
315.0 & 3.4 \\
337.5 & 7.9 \\
Frequency of calm winds & 3.2 \\
\hline &
\end{tabular}

sampler with a fixed depth intake method. The sample was drawn through a fixed intake located approximately at the centroid of the stream channel using a suction-lift type automatic sampler. The automatic sampler was programmed to begin sampling when flow occurred (stage rose above the crest of the weir), then filled as many as 241 -liter bottles at variable time intervals during the runoff event. The samples were collected at shorter intervals at the beginning of the runoff event (coinciding with increasing streamflow and the peak of streamflow) and at longer time intervals at the end of the runoff event (coinciding with decreasing streamflow). The samples were retrieved at the end of the runoff event or as soon as practical after all 24 samples were obtained, and the samples then were chilled and transported to the USGS South Texas Program Office for processing.

Of the 24 1-liter samples that were collected, as many as 6 samples were selected and analyzed to determine the suspended-sediment concentration. However, the sample intake was located such that some bedload likely was inadvertently drawn into the collection container, thereby potentially affecting the suspended-sediment measurements. Consequently, suspended-sediment data are not reported here. The remaining 1-liter samples were flow weighted and composited into a single water-quality sample representing the event mean concentration. To composite the samples, an aliquot, proportional to the amount of flow at the time the sample was taken, was measured from each of the remaining bottles. The measured volumes were then poured into a Teflon-lined stainlesssteel churn. As the composited sample was mixed in the churn, subsamples were drawn off for analysis by the USGS National Water Quality Laboratory (NWQL) in Denver, Colorado, and the USGS Reston Stable Isotope Laboratory (RSIL) in Reston Virginia, depending on the constituent.

\section{Sample Analysis}

Composited water-quality samples were analyzed for physical properties ( $\mathrm{pH}$ and specific conductance) by the USGS South Texas Program Office using methods described in the USGS National Field Manual for the Collection of Water Quality Data (U.S. Geological Survey, variously dated). Major ions, nutrients, and total organic carbon were analyzed and reported by the NWQL (appendix 4). Major inorganic ions were analyzed using methods described by Fishman and Friedman (1989) and Fishman (1993). Nutrients were analyzed using methods documented by Fishman (1993), O'Dell (1993), and Patton and Truitt (2000). Total organic carbon was analyzed using methods described by Clesceri and others (1998). Samples for analysis of the environmental isotopes were submitted to the USGS RSIL. $\delta$ D was analyzed using a gaseous hydrogen equilibration technique at $30^{\circ} \mathrm{C}$ (Coplen and others, 1991). $\delta^{18} \mathrm{O}$ was analyzed using a carbon dioxidewater equilibration technique (Epstein and Mayeda, 1953). The hydrogen and oxygen isotope results are reported as $\delta \mathrm{D}$ and $\delta^{18} \mathrm{O}$ (parts per thousand, per mil) relative to the Vienna Standard Mean Ocean Water (Coplen, 1994).

Quantified values of constituents represent measured concentrations greater than or equal to the detection level, as determined by the laboratory at the time of analysis, and were reported as specific numerical values. Censored values represent measured concentrations less than the reporting level, as determined by the laboratory at the time of analysis, were reported as " $\angle \mathrm{RL}$ ", where $\mathrm{RL}$ is the numerical reporting level. For each constituent, the numerical values of the detection and reporting levels can vary over time. In some cases, the reporting level used by the laboratory was greater than the detection level, so some quantified values can be reported that are less than censored values for the same constituent. In these cases, the quantified value is reported with an " $E$ " remark code.

\section{Quality Assurance}

USGS protocols were followed in the collection and processing of the water-quality samples (U.S. Geological Survey, variously dated). Sampling methods designed to minimize potential sample contamination and preserve the sample 
integrity were used. To minimize the potential contamination of the environmental samples, the autosamplers and collection bottles were cleaned between periods of sample collection. To clean the autosamplers, the sample tubing was flushed with a soap solution, rinsed with deionized water, flushed with a 5-percent solution of hydrochloric acid, and rerinsed with deionized water. Sample-collection bottles were washed in the laboratory following the same process. Quality-control samples were not collected at site $\mathrm{LC}_{\mathrm{Sw}}$; however, the sampling techniques and type of equipment used were the same as those at the Honey Creek State Natural Area during similar time periods where quality-control samples were collected. To document possible contamination, six field-blank samples were collected during the study at Honey Creek State Natural Area (Banta and Slattery, 2011). These field-blank samples were collected using inorganic blank water (certified ASTM Type I deionized water) provided by the NWQL. The blank water was pumped through the auto-sampler tubing and into 1 -liter collection bottles. The field-blank samples were processed following the same procedures as for the environmental samples and analyzed by the NWQL for major ions, nutrients, and total organic carbon. The majority of reported concentrations of these constituents were below the laboratory reporting levels. For the few exceptions where concentrations measured in the field-blank samples were greater than the reporting levels, the concentrations were an order of magnitude less than those of the environmental sample concentrations and, consequently, potential contamination of the environmental sample concentration was likely negligible (Banta and Slattery, 2011, appendix 4E).

\section{Hydrologic and Water-Quality Data}

The average annual rainfall at site $\mathrm{LC}_{\mathrm{SW}}$ from 2004-10 was 33 in., with a range of 15.6 in. to $55.7 \mathrm{in}$. (appendix 1). During 2003-10, the daily mean streamflow at site $\mathrm{LC}_{\mathrm{Sw}}$ ranged from 0 to 55 cubic feet per second $\left(\mathrm{ft}^{3} / \mathrm{s}\right)$, with an average daily mean streamflow of $0.08 \mathrm{ft}^{3} / \mathrm{s}$ (appendix 2). Because Laurel Canyon Creek is an ephemeral stream, long periods of no flow were recorded as a result of the dry conditions. The daily ET rates at site $\mathrm{LC}_{\mathrm{ET}}$ exhibited interannual and intraannual variability during the study period (fig. 6, appendix 3 ). An annual ET cycle was present, ranging from less than 1 millimeter per day $(\mathrm{mm} / \mathrm{d})$ during the winter season (December through February) to greater than $5 \mathrm{~mm} / \mathrm{d}$ during the summer months (June through August). Annual ET rates were not calculated because intermittent data gaps might bias the annual rates. The water-quality data collected at site $\mathrm{LC}_{\mathrm{Sw}}$ are presented in appendix 4.

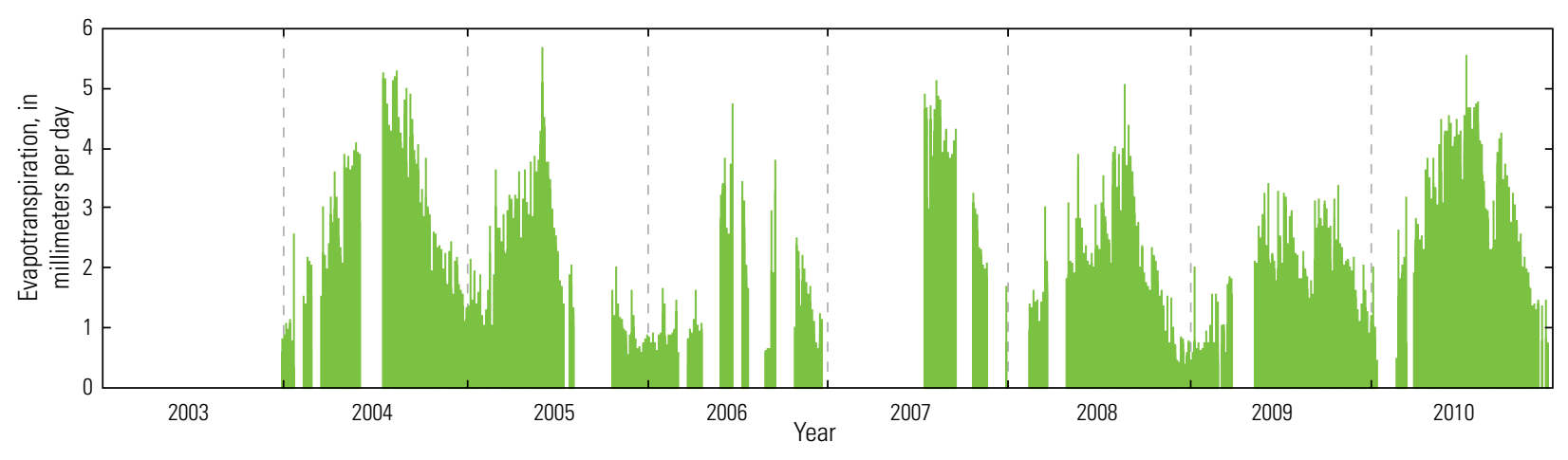

Figure 6. Evapotranspiration data at site $\mathrm{LC}_{\mathrm{ET}}$ (U.S. Geological station 293330098444300 Evapotranspiration Laurel Canyon watershed in the Government Canyon Station Natural Area, near Helotes, Texas), Government Canyon State Natural Area, Bexar County, Tex. 


\section{References}

Arya, S.P., 2001, Introduction to micrometeorology (2d ed.): San Diego, Calif., Academic Press, 420 p.

Ashworth, J.B., and Hopkins, J., 1995, Aquifers of Texas: Texas Water Development Board, Report 345, 69 p.

Banta, J.R., and Slattery, R.N., 2011, Effects of brush management on the hydrologic budget and water quality in and adjacent to Honey Creek State Natural Area, Comal County, Texas, 2001-10: U.S. Geological Survey Scientific Investigations Report, 2011-5226, 35 p.

Baxter, David, 2009, Selah, Bamberger Ranch PreserveLeopold/Lone Star Land Steward Award: Texas Wildlife Magazine, accessed April 9, 2011, at http://brp-journal. blogspot.com/2009/09/selah-bamberger-ranch-preserve. html.

Bos, M.G., ed., 1989, Discharge measurement structures (3d ed.): The Netherlands, International Institute for Land Reclamation and Improvement, $390 \mathrm{p}$.

Bowen, I.S., 1926, The ratio of heat losses by conduction and by evaporation from any water surface: Physics Review, v. 27 , p. $779-787$.

Bray, William, 1904, The timber of the Edwards Plateau of Texas-Its relation to climate, water supply, and soil: U.S. Department of Agriculture, Bulletin No. 49.

Brutsaert, Wilfried, 1982, Evaporation in the atmosphereTheory, history, applications: Dordrect Holland, D. Reidel Publishing Co., 299 p.

Burba, George, and Anderson, Daniel, 2010, A brief practical guide to eddy covariance flux measurements: Lincoln, Nebraska, LI-COR Biosciences, 214 p., accessed August 2011, at http://www.licor.com/env/applications/eddy _ covariance/book.html.

Campbell, G.S., 1972, Introduction to environmental biophysics: New York, Springer-Verlag, 159 p.

Campbell Scientific Inc., 1996, Instruction manual Q-7.1 net radiometer: Logan, Utah, $8 \mathrm{p}$.

Campbell Scientific Inc., 2003, Instruction manual HFT3 soil heat flux plate: Logan, Utah, 6 p.

Campbell Scientific Inc., 2004, Instruction manual CS616 and CS625 water content reflectometers: Logan, Utah, 6 p.

Clesceri, L.S., Greenberg, A.E., and Eaton, A.D., 1998, in L.S. Clesceri and others (ed.) Standard methods for the examination of water and waste water, 20th ed.: Washington, D.C., American Public Health Assoc., p. 2005-2605.
Coplen, T.B., 1994, Reporting of stable hydrogen, carbon, and oxygen isotopic abundances: Pure and Applied Chemistry, v. 66 , no. 2 , p. $273-276$.

Coplen, T.B., Wildman, J.D., and Chen, J., 1991, Improvements in the gaseous hydrogen-water equilibration technique for hydrogen isotope-ratio analysis: Analytical Chemistry, v. 63, p. $910-912$.

Duchon, C.E., and Essenberg, G.R., 2001, Comparative rainfall observations from a pit and above ground rain gauges with and without wind shields: Water Resources Research, v. 37 , no. 12 , p. 3253-3263.

Epstein, S., and Mayeda, T., 1953, Variation of O-18 content of water from natural sources: Geochimica Cosmochimica Acta, v. 4, p. 213-224.

Fishman, M.J., ed., 1993, Methods of analysis by the U.S. Geological Survey National Water Quality LaboratoryDetermination of inorganic and organic constituents in water and fluvial sediments: U.S. Geological Survey OpenFile Report 93-125, 217 p.

Fishman, M.J., and Friedman, L.C., 1989, Methods for determination of inorganic substances in water and fluvial sediments: U.S. Geological Survey Techniques of WaterResources Investigations, book 5, chap. A1, 545 p.

Griffith, Glenn, Bryce, Sandy, Omernik, James, Rogers, Anne, 2007, Ecoregions of Texas: Project report to the Texas Commission on Environmental Quality, p. 49-52, also available at ftp://ftp.epa.gov/wed/ecoregions/pubs/TXeco_Jan08_v8_ Cmprsd.pdf.

Heilman, J.L., Brittin, C.L., and Neale, C.M.U., 1989, Fetch requirements for Bowen ratio measurements of latent and sensible heat fluxes: Agricultural and Forest Meteorology, v. 44, issue 3-4, p. 261-273.

Huang, Yun., Wilcox, B.P., Stern, Libby, and PerottoBaldivieso, H., 2006, Springs on rangelands-Runoff dynamics and influence of woody plant cover: Hydrological Processes, v. 20, issue 15, p. 3277-3288.

Hulsing, Harry, 1967, Measurement of peak discharge at dams by indirect methods: U.S. Geological Survey Techniques of Water-Resources Investigations, book 3, chap. A5, 29 p.

Jensen, M.E., Burman, R.D., and Allen, R.G., eds., 1990, Evapotranspiration and irrigation water requirements: American Society of Civil Engineers Manuals and Reports on Engineering Practices No. 70, New York, American Society of Civil Engineers, 332 p.

Kennedy, E.J., 1983, Computation of continuous records of streamflow: U.S. Geological Survey, Techniques of Water-Resources Investigations, book 3, chap. A13, 53 p., accessed June 1, 2011, at http://pubs.usgs.gov/twri/ twri3-a13/. 
Kennedy, E.J., 1984, Discharge ratings at gaging stations: U.S. Geological Survey Techniques of Water-Resource Investigations, book 3, chap A10, 59 p., accessed June 3, 2011, at http://pubs.usgs.gov/twri/twri3-a10/.

Legates, D.R., and Deliberty, T.L., 1993, Precipitation bias in the United States: Water Resources Bulletin, American Water Resources Association, v. 29, no. 5, p. 855-861.

Maclay, R.W., 1995, Geology and hydrology of the Edwards Aquifer in the San Antonio area, Texas: U.S. Geological Survey Water-Resources Investigations Report 95-4186, $69 \mathrm{p}$.

National Climatic Data Center, 2011, Annual climatological summary: National Oceanic and Atmospheric Administration, accessed June 14, 2011, at http://cdo.ncdc.noaa.gov/ ancsum/ACS? coban=417945.

NovaLynx Corporation, 2001, Model 260-2595 Rain gauge calibrator user manual: Auburn, Calif., 7 p.

O’Dell J. ed., 1993, Method 365.1, Determination of phosphorus by semi-automated colorimetry: Environmental Monitoring Systems Laboratory, Office of Research and Development, U.S. Environmental Protection Agency, Revision 2, p. 17.

Ohmura, Atsumu, 1982, Objective criteria for rejecting data for Bowen ratio flux calculations: Journal of Applied Meteorology, v. 21, p. 595-598.

Patton, C.J., and Truitt, E.P., 2000, Methods of analysis by the U.S. Geological Survey National Water Quality Laboratory-Determination of ammonium plus organic nitrogen by a Kjeldahl digestion method and an automated photometric finish that includes digest cleanup by gas diffusion: U.S. Geological Survey Open-File Report 00-170, 31 p.

Radiation and Energy Balance Systems, Inc., 1996, Instruction Manual-Surface energy balance system cr10-3c manual: Bellevue, Washington, Radiation and Energy Balance Systems, Inc., 28 p., with updates per written communication, Charles Fritschen, variously dated.

Rantz, S.E., and others, 1982a, Measurement and computation of streamflow-Volume 1. Measurement of stage and discharge: U.S. Geological Survey Water-Supply Paper 2175, 284 p., accessed March 17, 2011, at http://pubs.usgs.gov/ wsp/wsp2175/pdf/WSP2175_vol1a.pdf.

Rantz, S.E., and others, 1982b, Measurement and computation of streamflow-Volume 2. Computation of discharge: U.S. Geological Survey Water-Supply Paper 2175, 631 p., accessed March 17, 2011, at http://pubs.usgs.gov/wsp/ wsp2175/pdf/WSP2175_vol2a.pdf.
Saleh, Ali, Wu, Hong, Brown, C.S., Teagarden, F.M., McWilliams, S.M., Hauck, L.M., and Millican, J.S., 2009, Effect of brush control on evapotranspiration in the North Concho River watershed using the eddy covariance technique: Journal of Soil and Water Conservation, v. 64, no. 5 .

Sauer, V.B., and Turnipseed, D.P., 2010, Stage measurement at gaging stations: U.S. Geological Survey Techniques and Methods book 3, chap. A7, 45 p., accessed March 17, 2011, at http://pubs.usgs.gov/tm/tm3-a7/pdf/tm3-a 7.pdf.

Stannard, David, 1997, A theoretically based determination of Bowen-ratio fetch requirements: Boundary-Layer Meteorology, v. 83, p. 375-406.

Stein, W.G., and Ozuna, G.B., 1995, Geologic framework and hydrogeologic characteristics of the Edwards aquifer recharge zone, Bexar County, Texas: U.S. Geological Survey Water-Resources Investigations Report 95-4030, 8 p., 1 sheet, scale 1:75,000.

Tennesen, M., 2008, When juniper and woody plants invade, water may retreat: Science, v. 332, p. 1630-1631.

Texas Parks and Wildlife Department, 2009, Golden-cheeked Warbler, 4 p. accessed March 9, 2011, at http://www. tpwd.state.tx.us/publications/pwdpubs/media/pwd_bk_ w7000_0013_golden_cheeked_warbler.pdf.

Thurow, T.L., and Hester, W.H., 1997, How an increase or reduction in juniper cover alters rangeland hydrology: Juniper ecology and management, 1997 Juniper Symposium, chap. 4, accessed March 9, 2012, at http://texnat.tamu.edu/ library/symposia/juniper-ecology-and-management/howan-increase-or-reduction-in-juniper-cover-alters-rangelandhydrology/.

Turnipseed, D.P., and Sauer, V.B., 2010, Discharge measurements at gaging stations: U.S. Geological Survey Techniques and Methods book 3, chap. A8, 87 p., accessed March 17, 2011, at http://pubs.usgs.gov/tm/tm3-a8/pdf/ tm3-a8.pdf.

U.S. Department of Agriculture Natural Resources Conservation Service, 2010, Web soil survey (WSS): U.S. Department of Agriculture Natural Resources Conservation Service, accessed March 23, 2011, at http://websoilsurvey. nrcs.usda.gov/app/WebSoilSurvey.aspx.

U.S. Geological Survey, 2005: Office of Surface Water Technical Memorandum No. 2006.01, revised December 2009-Collection, quality assurance, and presentation of precipitation data, 29 p., accessed June 1, 2011, at http://water.usgs.gov/admin/memo/SW/sw06.012_ Revised_122009.pdf. 
U.S. Geological Survey, variously dated, National field manual for the collection of water-quality data: U.S. Geological Survey Techniques of Water-Resources Investigations, book 9, chaps. A1-A9, accessed March 17, 2011, at http://pubs.water.usgs.gov/twri9a.

U.S. Geological Survey, 2011, National Water Information System: accessed in March 2011 at http://waterdata.usgs. gov/tx/nwis/.
Van Auken, O.W., 2000, Shrub invasions of North American semiarid grasslands: Annual Review of Ecology and Systematics, v. 31, p. 197-215.

WRPLOT View, 2010, Wind rose plots for meteorological data, version 6.5.2: Waterloo, Ontario, Lakes Environmental Software. 
Appendixes 1-4 

Appendix 1. Daily total rainfall during 2003-10 at site $\mathrm{LC}_{\mathrm{sw}}$ (U.S. Geological Survey streamflow-gaging station 08180942 Laurel Canyon Creek near Helotes, Texas), Government Canyon State Natural Area, Bexar County, Tex.

[-- , not collected or calculated or not applicable]

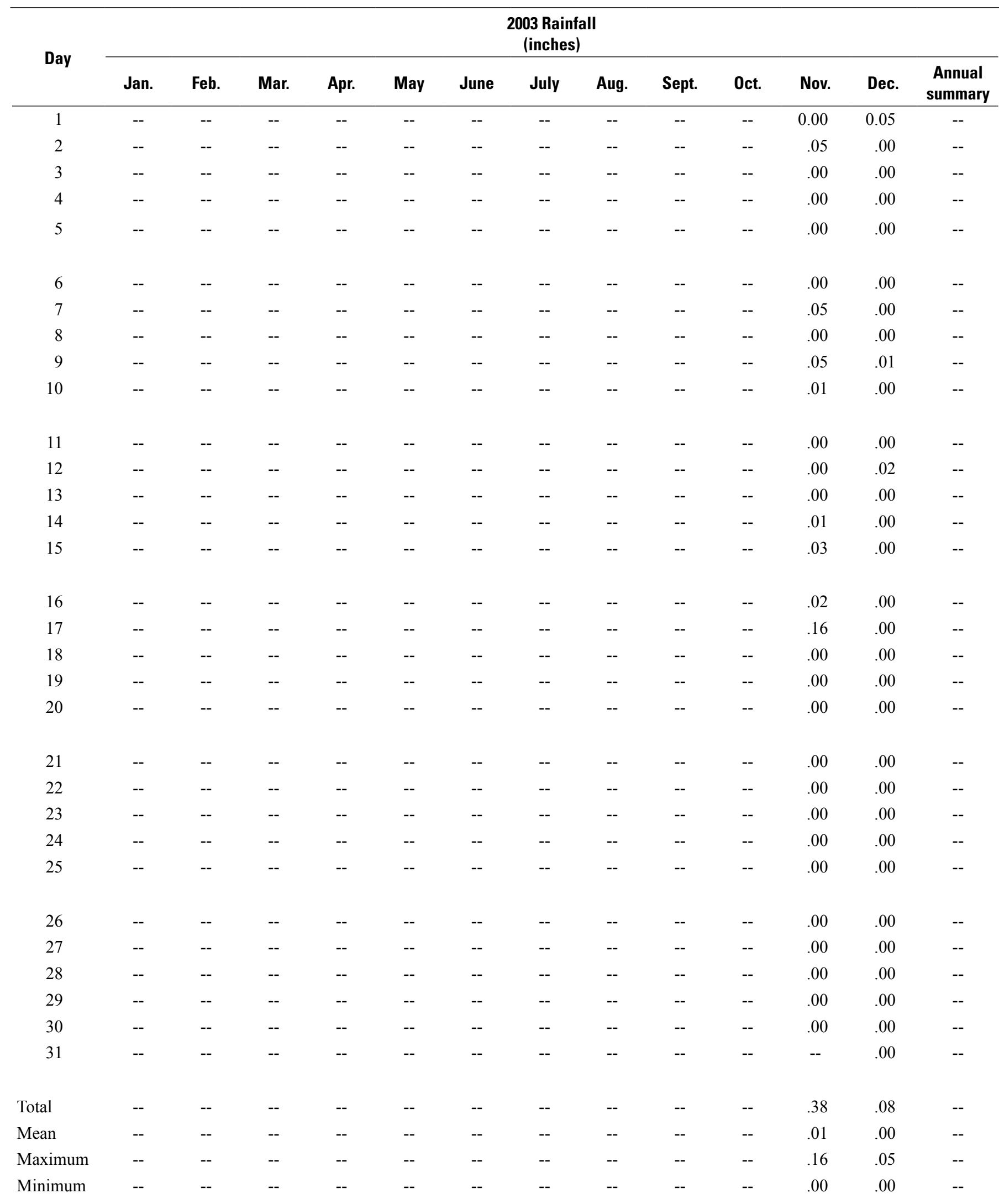




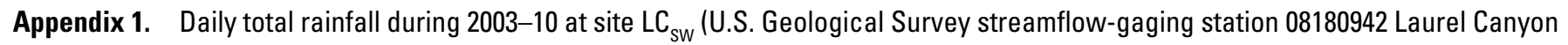
Creek near Helotes, Texas), Government Canyon State Natural Area, Bexar County, Tex.-Continued.

[-- , not collected or calculated or not applicable; e, estimated]

\begin{tabular}{|c|c|c|c|c|c|c|c|c|c|c|c|c|c|}
\hline \multirow{2}{*}{ Day } & \multicolumn{13}{|c|}{$\begin{array}{l}2004 \text { Rainfall } \\
\text { (inches) }\end{array}$} \\
\hline & Jan. & Feb. & Mar. & Apr. & May & June & July & Aug. & Sept. & Oct. & Nov. & Dec. & $\begin{array}{c}\text { Annual } \\
\text { summary }\end{array}$ \\
\hline 1 & 0.08 & 0.02 & 0.00 & 0.00 & 1.29 & 0.00 & 0.00 & 0.00 & 0.00 & $\mathrm{e} 0.00$ & 0.56 & 0.00 & -- \\
\hline 2 & .00 & .00 & .03 & 1.98 & .00 & .00 & .00 & .00 & .00 & e1.57 & .00 & .00 & -- \\
\hline 3 & .00 & .00 & .01 & .01 & .00 & .06 & .00 & .00 & .00 & e. 00 & .00 & .00 & -- \\
\hline 5 & .00 & .01 & .00 & .02 & .00 & .00 & .00 & .00 & .00 & .00 & .00 & .00 & -- \\
\hline 6 & .00 & .00 & .00 & .11 & .00 & .00 & .00 & .77 & .09 & .00 & .00 & .07 & -- \\
\hline 7 & .01 & .00 & .00 & .01 & 1.55 & .80 & .00 & .24 & .00 & .02 & .00 & .00 & -- \\
\hline 11 & .00 & .18 & .00 & .70 & .11 & .00 & .04 & .00 & .00 & .00 & .00 & .00 & -- \\
\hline 12 & .00 & .00 & .59 & .00 & .10 & .00 & .01 & .00 & .00 & .00 & .00 & .00 & -- \\
\hline 13 & .00 & .06 & .46 & .00 & .04 & .32 & .00 & .00 & .03 & .05 & .08 & .00 & -- \\
\hline 14 & .55 & .05 & 1.14 & .00 & .14 & .00 & .00 & .00 & .04 & .18 & 1.35 & .00 & -- \\
\hline 15 & .94 & .00 & .00 & .00 & .00 & .00 & .00 & .00 & .00 & .00 & .55 & .00 & -- \\
\hline 16 & 1.02 & .00 & .01 & .00 & .00 & .00 & .00 & .00 & .00 & .00 & 2.52 & .00 & -- \\
\hline 17 & .00 & .00 & .00 & .00 & .00 & .00 & .00 & .00 & .00 & .00 & 1.34 & .00 & -- \\
\hline 18 & .00 & .00 & .00 & .00 & .00 & .00 & .00 & .00 & .00 & .00 & .00 & .00 & -- \\
\hline 24 & .47 & 1.05 & .02 & 1.77 & .00 & .43 & .00 & .00 & .00 & 2.04 & .00 & .00 & -- \\
\hline 25 & .01 & .00 & .00 & .02 & .00 & 1.34 & .01 & .00 & .00 & .00 & .00 & .00 & -- \\
\hline 26 & .00 & .00 & .02 & .02 & .00 & .12 & .00 & .00 & .00 & .00 & .00 & .00 & -- \\
\hline 27 & .00 & .00 & .06 & .00 & .00 & 2.66 & .00 & .00 & .00 & .04 & .00 & .00 & -- \\
\hline 28 & .00 & .00 & .00 & .40 & .01 & .89 & .00 & .09 & .00 & .00 & .00 & .00 & -- \\
\hline 29 & .08 & .33 & .04 & .14 & .00 & 1.44 & .00 & .02 & .00 & .00 & .02 & .00 & -- \\
\hline 30 & .00 & -- & .00 & .01 & .02 & .28 & 2.78 & .01 & .00 & .00 & .03 & .00 & -- \\
\hline 31 & .01 & -- & .00 & -- & .00 & -- & .00 & .00 & -- & .24 & -- & .00 & -- \\
\hline Total & 3.24 & 2.22 & 2.96 & 7.21 & 3.76 & 11.81 & 3.00 & 4.92 & 1.79 & 4.69 & 10.05 & .07 & 55.72 \\
\hline Mean & .10 & .08 & .10 & .24 & .12 & .39 & .10 & .16 & .06 & .15 & .34 & .00 & .15 \\
\hline Maximum & 1.02 & 1.05 & 1.14 & 1.98 & 1.55 & 2.66 & 2.78 & 1.94 & 1.14 & 2.04 & 2.93 & .07 & 2.93 \\
\hline Minimum & .00 & .00 & .00 & .00 & .00 & .00 & .00 & .00 & .00 & .00 & .00 & .00 & .00 \\
\hline
\end{tabular}


Appendix 1. Daily total rainfall during 2003-10 at site $\mathrm{LC}_{\mathrm{sw}}$ (U.S. Geological Survey streamflow-gaging station 08180942 Laurel Canyon Creek near Helotes, Texas), Government Canyon State Natural Area, Bexar County, Tex.-Continued.

[-- , not collected or calculated or not applicable $]$

2005 Rainfall

(inches)

\begin{tabular}{|c|c|c|c|c|c|c|c|c|c|c|c|c|c|}
\hline \multirow{2}{*}{ Day } & \multicolumn{13}{|c|}{ (inches) } \\
\hline & Jan. & Feb. & Mar. & Apr. & May & June & July & Aug. & Sept. & Oct. & Nov. & Dec. & $\begin{array}{c}\text { Annual } \\
\text { summary }\end{array}$ \\
\hline 1 & 0.01 & 0.37 & 0.00 & 0.00 & 0.00 & 0.82 & 0.00 & 0.00 & 0.00 & 0.00 & 0.00 & 0.00 & -- \\
\hline 2 & .42 & .00 & .06 & .00 & .00 & .00 & .00 & .00 & .00 & .00 & .00 & .00 & -- \\
\hline 3 & .11 & .00 & .00 & .00 & .01 & .00 & .00 & .00 & .00 & .07 & .00 & .00 & -- \\
\hline 4 & .00 & .00 & .01 & .00 & .03 & .00 & .00 & .00 & .00 & .00 & .00 & .01 & -- \\
\hline 5 & .02 & .11 & .55 & .00 & .00 & .00 & .00 & .00 & .00 & .00 & .00 & .00 & -- \\
\hline 6 & .00 & .36 & .43 & .00 & .00 & .01 & .00 & .18 & .01 & .00 & .00 & .00 & -- \\
\hline 7 & .01 & .89 & .10 & .00 & .01 & .00 & .00 & .00 & .01 & .13 & .00 & .02 & -- \\
\hline 8 & .01 & .01 & .00 & .00 & .84 & .00 & .01 & .43 & .00 & .00 & .00 & .00 & -- \\
\hline 9 & .00 & .00 & .00 & .00 & .00 & .00 & .00 & .12 & .00 & .00 & .00 & .00 & -- \\
\hline 10 & .01 & .00 & .00 & .00 & .00 & .00 & .00 & 1.44 & 1.17 & .47 & .00 & .00 & -- \\
\hline 11 & .00 & .00 & .00 & .31 & .00 & .00 & .00 & .00 & .40 & .35 & .00 & .00 & -- \\
\hline 12 & .00 & .12 & .00 & .00 & .00 & .00 & .00 & .00 & .01 & .00 & .00 & .00 & -- \\
\hline 13 & .00 & .02 & .00 & .00 & .00 & .00 & .00 & .00 & .00 & .00 & .01 & .00 & -- \\
\hline 14 & .00 & .00 & .00 & .00 & .00 & .00 & .00 & .01 & .00 & .00 & .00 & .01 & -- \\
\hline 15 & .00 & .00 & .02 & .00 & .39 & .00 & .15 & .00 & .00 & .00 & .00 & .00 & -- \\
\hline 16 & .00 & .00 & .16 & .00 & .13 & .00 & .05 & .00 & .00 & .00 & .00 & .02 & -- \\
\hline 17 & .00 & .00 & .00 & .00 & .00 & .00 & .00 & .00 & .00 & .00 & .00 & .01 & -- \\
\hline 18 & .00 & .00 & .00 & .03 & .00 & .00 & .00 & .00 & .00 & .00 & .00 & .00 & -- \\
\hline 19 & .00 & .22 & .00 & .00 & .00 & .00 & .00 & .48 & .00 & .00 & .00 & .00 & -- \\
\hline 20 & .00 & .00 & .00 & .00 & .00 & .00 & .04 & .00 & .00 & .00 & .00 & .00 & -- \\
\hline 21 & .00 & .01 & .00 & .00 & .00 & .00 & .24 & .00 & .00 & .00 & .00 & .00 & -- \\
\hline 22 & .00 & .00 & .00 & .00 & .00 & .00 & .00 & .00 & .00 & .00 & .00 & .00 & -- \\
\hline 23 & .00 & .02 & .00 & .00 & .00 & .00 & .00 & .00 & .00 & .00 & .00 & .00 & -- \\
\hline 24 & .00 & .44 & .00 & .00 & .00 & .00 & .00 & .00 & .00 & .12 & .00 & .00 & -- \\
\hline 25 & .00 & .00 & .00 & .00 & .00 & .00 & .00 & .00 & .00 & .00 & .00 & .00 & -- \\
\hline 26 & .00 & .75 & .46 & .00 & .04 & .00 & .00 & .00 & .00 & .00 & .86 & .00 & -- \\
\hline 27 & 1.85 & .00 & .00 & .00 & .00 & .00 & .02 & .00 & .00 & .14 & .00 & .00 & -- \\
\hline 28 & .09 & .00 & .00 & .00 & 1.34 & .00 & .02 & .60 & .00 & .01 & .00 & .00 & -- \\
\hline 29 & .00 & -- & .00 & .00 & .35 & .00 & .03 & .07 & .00 & .00 & .00 & .00 & -- \\
\hline 30 & .13 & -- & .00 & .00 & .02 & .00 & .00 & .09 & .00 & .00 & .00 & .00 & -- \\
\hline 31 & .03 & -- & .02 & -- & .00 & -- & .00 & .00 & -- & .13 & -- & .00 & -- \\
\hline Total & 2.69 & 3.32 & 1.81 & .34 & 3.16 & .83 & .56 & 3.42 & 1.60 & 1.42 & .87 & .07 & 20.09 \\
\hline Mean & .09 & .12 & .06 & .01 & .10 & .03 & .02 & .11 & .05 & .05 & .03 & .01 & .06 \\
\hline Maximum & 1.85 & .89 & .55 & .31 & 1.34 & .82 & .24 & 1.44 & 1.17 & .47 & .86 & .07 & 1.85 \\
\hline Minimum & .00 & .00 & .00 & .00 & .00 & .00 & .00 & .00 & .00 & .00 & .00 & .00 & .00 \\
\hline
\end{tabular}




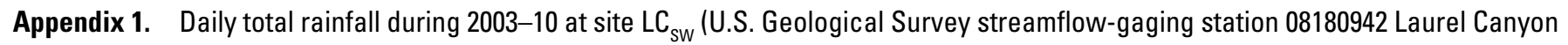
Creek near Helotes, Texas), Government Canyon State Natural Area, Bexar County, Tex.-Continued.

$[--$, not collected or calculated or not applicable $]$

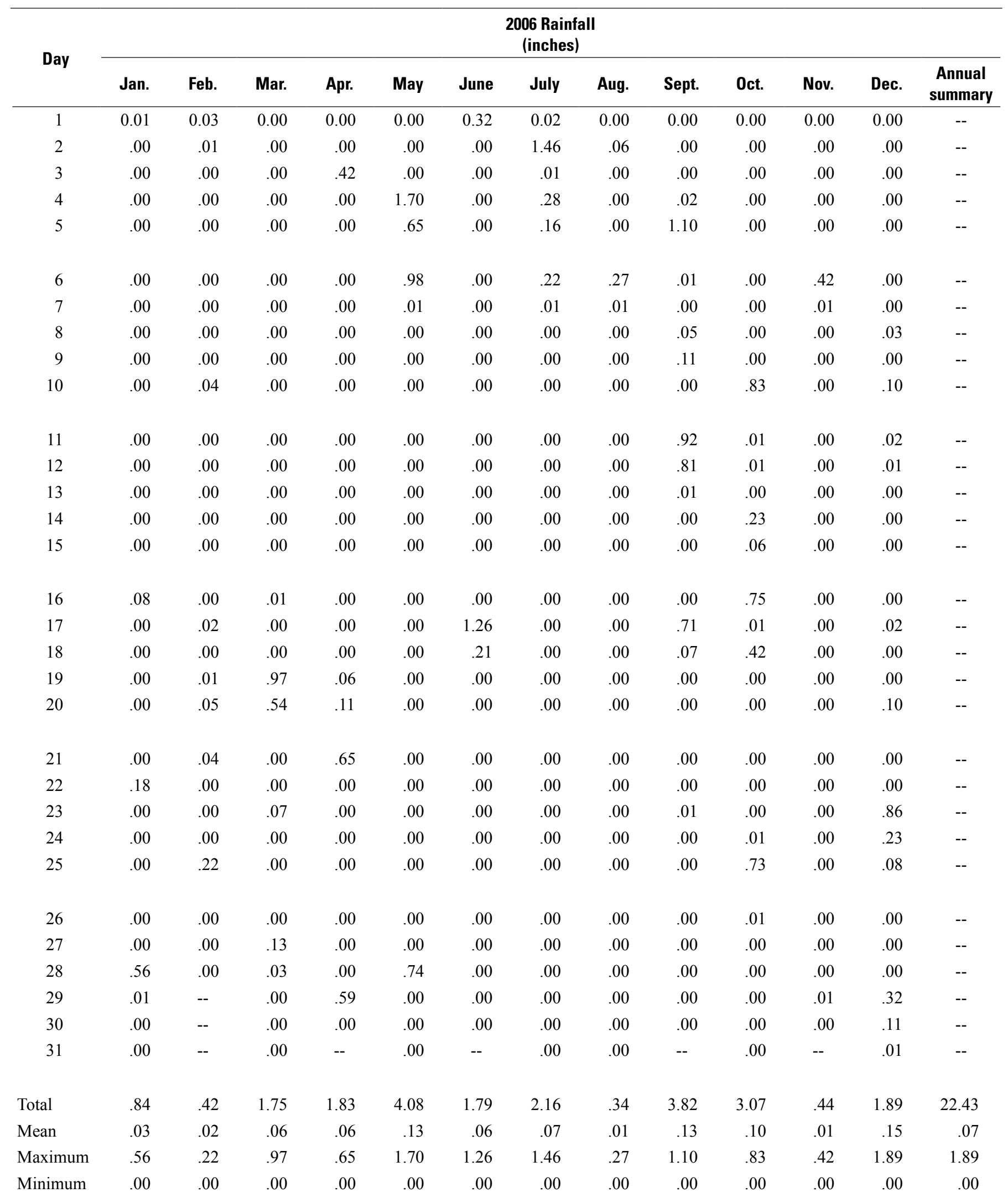


Appendix 1. Daily total rainfall during 2003-10 at site $\mathrm{LC}_{\mathrm{sw}}$ (U.S. Geological Survey streamflow-gaging station 08180942 Laurel Canyon Creek near Helotes, Texas), Government Canyon State Natural Area, Bexar County, Tex.-Continued.

[-- , not collected or calculated or not applicable $]$

2007 Rainfall

(inches)

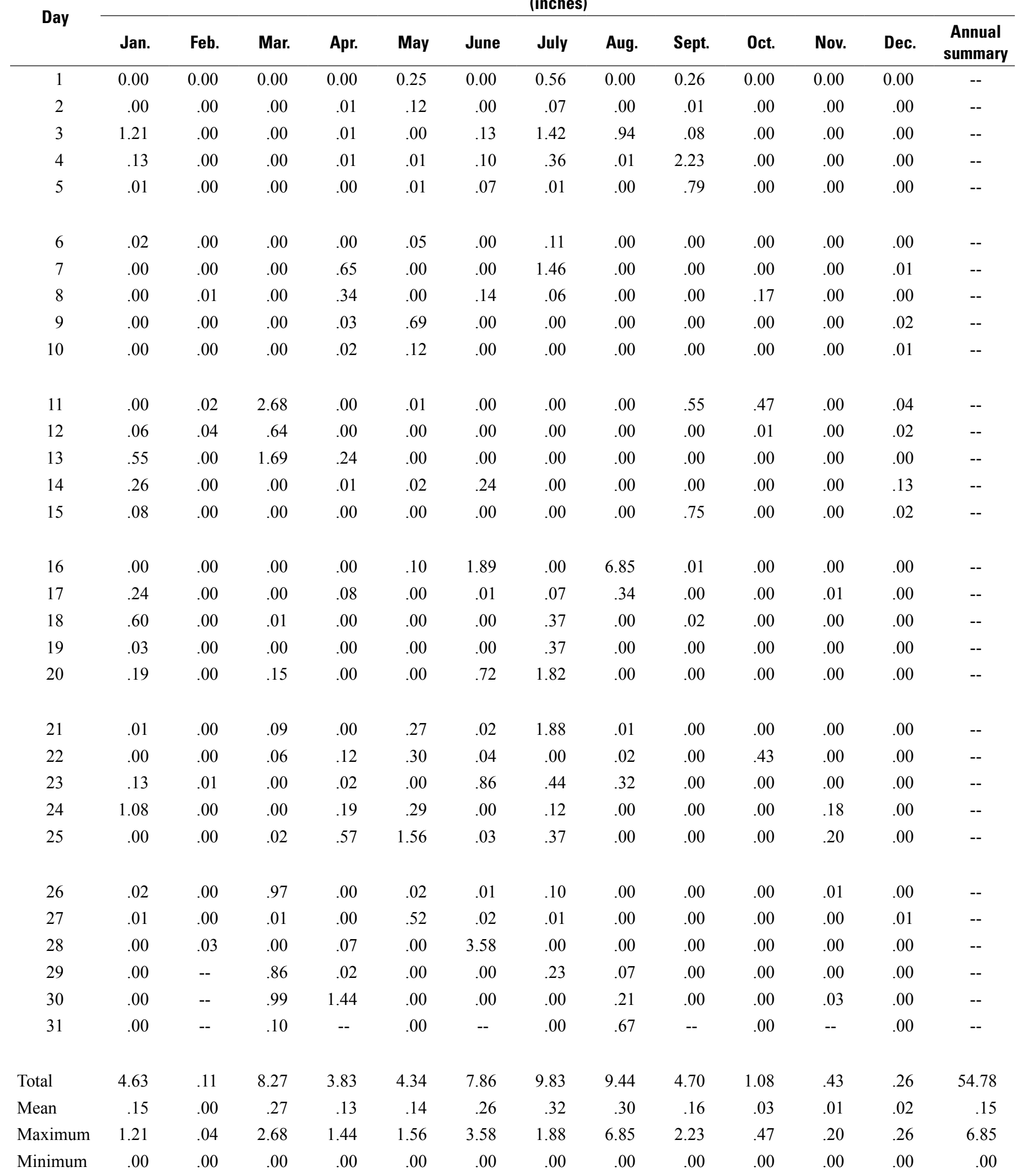


Appendix 1. Daily total rainfall during 2003-10 at site LC ${ }_{S W}$ (U.S. Geological Survey streamflow-gaging station 08180942 Laurel Canyon Creek near Helotes, Texas), Government Canyon State Natural Area, Bexar County, Tex.-Continued.

$[--$, not collected or calculated or not applicable $]$

\begin{tabular}{|c|c|c|c|c|c|c|c|c|c|c|c|c|c|}
\hline \multirow{2}{*}{ Day } & \multicolumn{13}{|c|}{$\begin{array}{l}2008 \text { Rainfall } \\
\text { (inches) }\end{array}$} \\
\hline & Jan. & Feb. & Mar. & Apr. & May & June & July & Aug. & Sept. & Oct. & Nov. & Dec. & $\begin{array}{c}\text { Annual } \\
\text { summary }\end{array}$ \\
\hline 1 & 0.00 & 0.00 & 0.00 & 0.02 & 0.00 & 0.00 & 0.00 & 0.00 & 0.00 & 0.00 & 0.00 & 0.00 & -- \\
\hline 2 & .00 & .00 & .00 & .00 & .00 & .00 & .00 & .00 & .00 & .00 & .00 & .00 & -- \\
\hline 3 & .00 & .00 & .04 & .00 & .00 & .00 & .02 & .00 & .00 & .00 & .00 & .00 & -- \\
\hline 5 & .00 & .00 & .00 & .00 & .01 & .00 & .05 & .13 & .00 & .00 & .00 & .00 & -- \\
\hline 6 & .00 & .00 & .26 & .00 & .00 & .01 & .01 & .07 & .00 & .00 & .02 & .00 & -- \\
\hline 7 & .00 & .00 & .00 & .01 & .00 & .01 & .42 & .00 & .00 & .00 & .00 & .00 & -- \\
\hline 11 & .00 & .00 & .00 & .00 & .00 & .00 & .00 & .00 & .00 & .00 & .00 & .00 & -- \\
\hline 12 & .00 & .00 & .00 & .00 & .00 & .00 & .00 & 1.52 & .00 & .00 & .00 & .00 & -- \\
\hline 13 & .00 & .00 & .00 & .00 & .00 & .02 & .00 & .00 & .19 & .69 & .00 & .00 & -- \\
\hline 14 & .00 & .00 & .00 & .00 & .81 & .00 & .00 & .00 & .12 & .00 & .00 & .00 & -- \\
\hline 15 & .03 & .07 & .00 & .00 & .27 & .00 & .00 & .00 & .00 & .72 & .00 & .02 & -- \\
\hline 16 & .00 & .31 & .00 & .00 & .23 & .00 & .00 & .00 & .00 & .00 & .00 & .00 & -- \\
\hline 17 & .00 & .00 & .00 & .00 & .00 & .00 & .00 & .00 & .00 & .00 & .00 & .03 & -- \\
\hline 23 & .00 & .00 & .00 & .00 & .00 & .00 & .21 & .52 & .00 & .00 & .00 & .02 & -- \\
\hline 24 & .01 & .00 & .00 & .00 & .00 & .00 & 2.30 & .98 & .00 & .00 & .00 & .02 & -- \\
\hline 25 & .00 & .00 & .00 & .11 & .00 & .00 & .00 & .03 & .00 & .00 & .00 & .00 & -- \\
\hline 26 & .00 & .00 & .00 & .01 & .00 & .00 & .00 & .00 & .00 & .00 & .00 & .00 & -- \\
\hline 27 & .00 & .00 & .00 & .00 & .00 & .00 & .00 & .00 & .00 & .01 & .00 & .00 & -- \\
\hline 28 & .02 & .00 & .00 & .00 & .00 & .00 & .00 & .00 & .00 & .00 & .01 & .00 & -- \\
\hline 29 & .00 & .00 & .03 & .00 & .01 & .01 & .00 & .00 & .00 & .00 & .00 & .00 & -- \\
\hline 30 & .00 & -- & .06 & .00 & .00 & .00 & .00 & .00 & .00 & .00 & .00 & .00 & -- \\
\hline 31 & .02 & -- & .01 & -- & .00 & -- & .00 & .00 & -- & .00 & -- & .00 & -- \\
\hline Total & .35 & .38 & 1.55 & 1.14 & 1.55 & .66 & 3.58 & 4.27 & .33 & 1.42 & .04 & .33 & 15.60 \\
\hline Mean & .01 & .01 & .05 & .04 & .05 & .02 & .12 & .14 & .01 & .05 & .00 & .03 & .04 \\
\hline Maximum & .15 & .31 & .94 & .93 & .81 & .54 & 2.30 & 1.52 & .19 & .72 & .02 & .33 & .30 \\
\hline Minimum & .00 & .00 & .00 & .00 & .00 & .00 & .00 & .00 & .00 & .00 & .00 & .00 & .00 \\
\hline
\end{tabular}


Appendix 1. Daily total rainfall during 2003-10 at site $\mathrm{LC}_{\mathrm{sw}}$ (U.S. Geological Survey streamflow-gaging station 08180942 Laurel Canyon Creek near Helotes, Texas), Government Canyon State Natural Area, Bexar County, Tex.-Continued.

[-- , not collected or calculated or not applicable; e, estimated]

2009

Rainfall (inches)

\begin{tabular}{|c|c|c|c|c|c|c|c|c|c|c|c|c|c|}
\hline \multirow{2}{*}{ Day } & \multicolumn{13}{|c|}{ Raintall (Inches) } \\
\hline & Jan. & Feb. & Mar. & Apr. & May & June & July & Aug. & Sept. & Oct. & Nov. & Dec. & $\begin{array}{l}\text { Annual } \\
\text { summary }\end{array}$ \\
\hline 1 & 0.00 & 0.00 & 0.00 & 0.00 & 0.00 & 0.00 & 0.00 & 0.00 & 0.00 & 0.00 & 0.00 & 0.51 & -- \\
\hline 2 & .00 & .00 & .00 & .00 & .00 & .00 & .00 & .00 & .00 & .00 & .00 & .00 & -- \\
\hline 3 & .00 & .00 & .00 & .00 & .00 & .19 & .00 & .00 & .00 & .28 & .00 & .00 & -- \\
\hline 4 & .00 & .00 & .00 & .00 & .00 & .00 & .00 & .00 & .03 & 2.06 & .00 & .00 & -- \\
\hline 5 & .05 & .00 & .00 & .00 & .00 & .00 & .00 & .00 & .17 & .01 & .00 & .00 & -- \\
\hline 6 & .26 & .00 & .00 & .00 & .00 & .00 & .89 & .00 & .16 & .00 & .00 & .00 & -- \\
\hline 7 & .00 & .00 & .00 & .00 & .00 & .00 & .01 & .00 & .00 & .00 & .00 & .03 & -- \\
\hline 8 & .00 & .00 & .00 & .00 & .00 & .00 & .00 & .00 & .00 & .00 & .90 & .02 & -- \\
\hline 9 & .00 & .11 & .00 & .00 & .00 & .00 & .00 & .00 & .18 & 1.53 & .00 & .01 & -- \\
\hline 10 & .00 & .00 & .00 & .00 & .00 & .00 & .00 & .00 & 1.89 & .00 & .00 & .00 & -- \\
\hline 11 & .00 & .00 & .30 & .00 & .00 & .00 & .00 & .00 & 1.27 & .12 & .01 & .07 & -- \\
\hline 12 & .00 & .00 & 1.49 & .20 & .00 & .00 & .00 & .17 & .03 & .00 & .00 & .04 & -- \\
\hline 13 & .00 & .00 & .04 & .00 & .00 & .00 & .00 & .00 & .00 & .07 & .00 & .01 & -- \\
\hline 14 & .00 & .00 & .00 & .00 & .00 & .00 & .00 & .00 & .00 & .00 & .01 & .02 & -- \\
\hline 15 & .00 & .00 & .03 & .00 & .00 & .00 & .00 & .00 & .00 & .01 & .00 & .00 & -- \\
\hline 16 & .00 & .00 & .00 & .04 & 1.44 & .00 & .00 & .00 & .00 & .00 & .17 & .06 & -- \\
\hline 17 & .00 & .08 & .00 & .35 & .00 & .00 & .00 & .00 & .00 & .00 & .00 & .24 & -- \\
\hline 18 & .00 & .01 & .00 & .02 & .00 & .00 & 1.08 & .00 & .00 & .00 & .00 & .00 & -- \\
\hline 19 & .00 & .00 & .00 & .00 & .00 & .00 & .00 & .00 & .00 & .00 & .09 & .01 & -- \\
\hline 20 & .00 & .00 & .00 & .00 & .00 & .00 & .06 & .00 & .00 & .00 & .81 & .00 & -- \\
\hline 21 & .00 & .00 & .00 & .00 & .00 & .00 & .00 & .00 & .00 & .88 & .00 & .00 & -- \\
\hline 22 & .00 & .00 & .00 & .00 & .00 & .00 & .00 & .00 & 1.01 & 1.22 & .00 & .00 & -- \\
\hline 23 & .00 & .00 & .00 & .00 & .05 & .00 & .00 & .00 & .20 & .00 & .01 & .03 & -- \\
\hline 24 & .00 & .00 & .05 & .00 & .04 & .00 & .00 & .00 & .11 & .00 & .01 & .16 & -- \\
\hline 25 & .00 & .00 & .00 & .01 & .01 & .60 & .00 & .00 & .01 & .00 & .00 & .00 & -- \\
\hline 26 & .00 & .00 & .35 & .08 & .14 & .00 & .00 & .00 & .00 & 1.37 & .00 & .00 & -- \\
\hline 27 & .07 & .00 & .02 & .66 & .00 & .00 & .00 & .39 & .00 & .00 & .00 & .00 & -- \\
\hline 28 & .00 & .00 & .00 & .05 & .00 & .00 & .00 & .06 & .00 & .01 & .00 & .00 & -- \\
\hline 29 & .00 & -- & .00 & .00 & .04 & .00 & .00 & .00 & .04 & .00 & .00 & .25 & -- \\
\hline 30 & .00 & -- & .00 & .00 & .00 & .00 & .07 & .00 & .02 & .00 & .13 & .01 & -- \\
\hline 31 & .00 & -- & .20 & -- & .00 & -- & .00 & .00 & -- & .00 & -- & .01 & -- \\
\hline Total & .38 & .20 & 2.48 & 1.41 & 1.72 & .79 & 2.11 & .62 & 5.12 & 7.56 & 2.14 & 1.48 & 26.01 \\
\hline Mean & .01 & .01 & .08 & .05 & .06 & .03 & .07 & .02 & .17 & .24 & .07 & .09 & .07 \\
\hline Maximum & .26 & .11 & 1.49 & .66 & 1.44 & .60 & 1.08 & .39 & 1.89 & 2.06 & .90 & 1.48 & 2.06 \\
\hline Minimum & .00 & .00 & .00 & .00 & .00 & .00 & .00 & .00 & .00 & .00 & .00 & .00 & .00 \\
\hline
\end{tabular}


Appendix 1. Daily total rainfall during 2003-10 at site LC ${ }_{S W}$ (U.S. Geological Survey streamflow-gaging station 08180942 Laurel Canyon Creek near Helotes, Texas), Government Canyon State Natural Area, Bexar County, Tex.-Continued.

$[--$, not collected or calculated or not applicable; e, estimated]

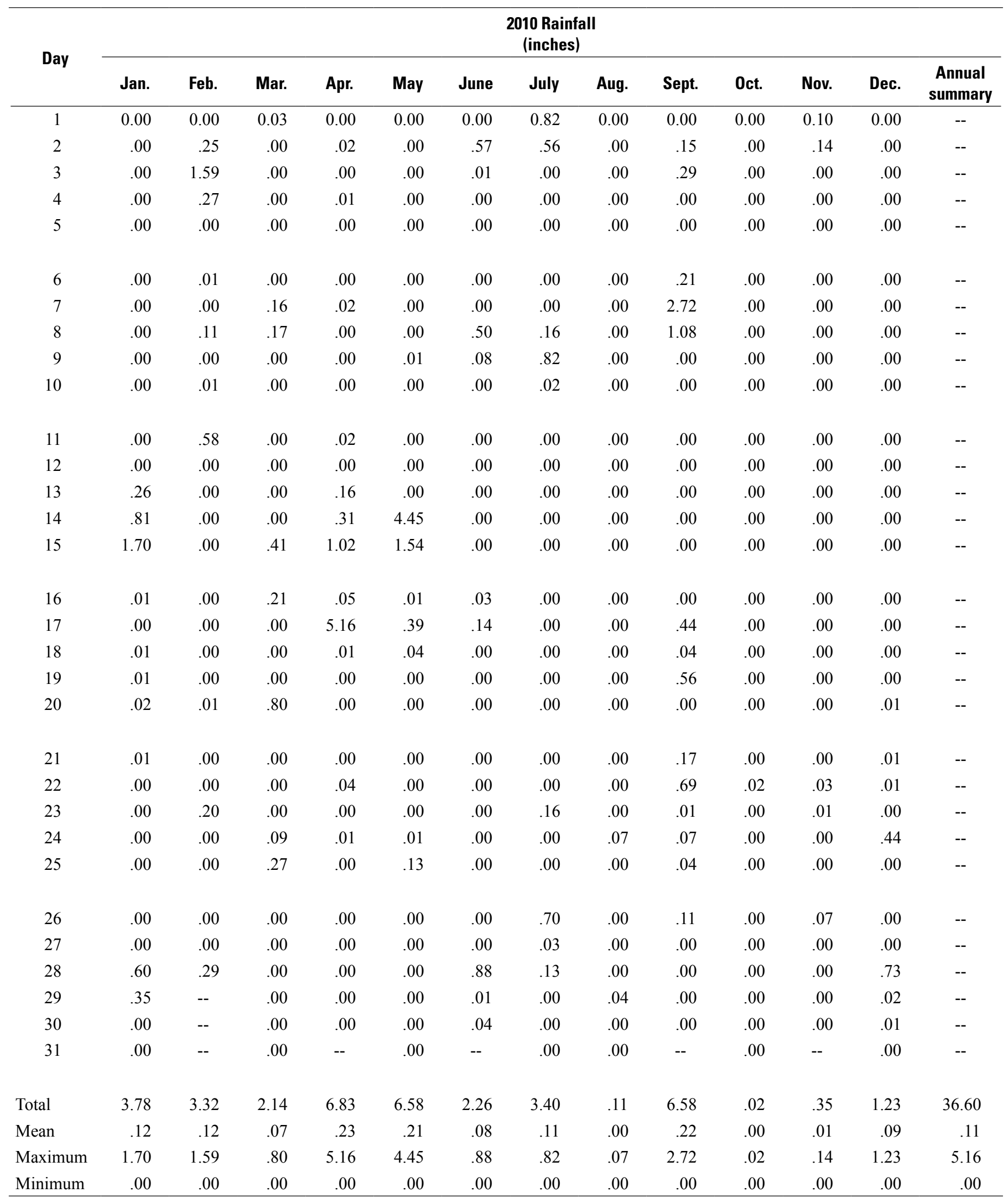


Appendix 2. Daily mean streamflow during 2002-10 at site LC $C_{S W}$ (U.S. Geological Survey streamflow-gaging station 08180942 Laurel Canyon Creek near Helotes, Texas), Government Canyon State Natural Area, Bexar County, Tex.

[-- , not collected or calculated or not applicable; e, estimated]

2002 Streamflow

(cubic feet per second)

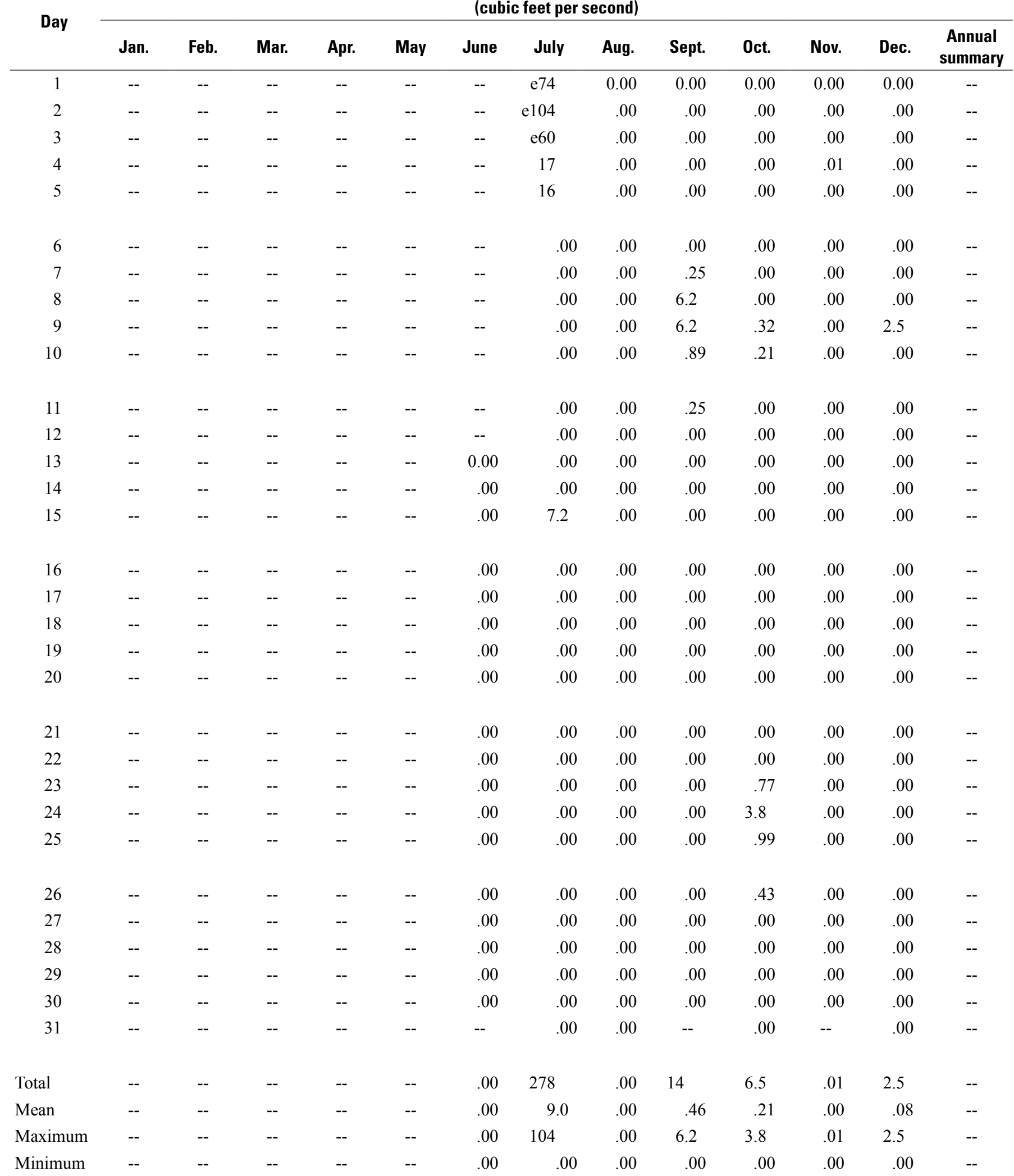


Appendix 2. Daily mean streamflow during 2002-10 at site $\mathrm{LC}_{\mathrm{SW}}$ (U.S. Geological Survey streamflow-gaging station 08180942 Laurel Canyon Creek near Helotes, Texas), Government Canyon State Natural Area, Bexar County, Tex.-Continued.

$[--$, not collected or calculated or not applicable; e, estimated]

\begin{tabular}{|c|c|c|c|c|c|c|c|c|c|c|c|c|c|}
\hline \multirow{2}{*}{ Day } & \multicolumn{13}{|c|}{$\begin{array}{c}2003 \text { Streamflow } \\
\text { (cubic feet per second) }\end{array}$} \\
\hline & Jan. & Feb. & Mar. & Apr. & May & June & July & Aug. & Sept. & Oct. & Nov. & Dec. & $\begin{array}{l}\text { Annual } \\
\text { summary }\end{array}$ \\
\hline 1 & 0.00 & 0.00 & 0.00 & 0.00 & 0.00 & 0.00 & 0.00 & 0.00 & 0.00 & 0.00 & 0.00 & 0.00 & -- \\
\hline 2 & .00 & .00 & .00 & .00 & .00 & .00 & .00 & .00 & .00 & .00 & .00 & .00 & -- \\
\hline 3 & .00 & .00 & .00 & .00 & .00 & .00 & .02 & .00 & .00 & .00 & .00 & .00 & -- \\
\hline 5 & .00 & .00 & .00 & .00 & .00 & .00 & 2.8 & .00 & .00 & .00 & .00 & .00 & -- \\
\hline 6 & .00 & .00 & .00 & .00 & .00 & .00 & .62 & .00 & .00 & .00 & .00 & .00 & -- \\
\hline 7 & .00 & .00 & .00 & .00 & .00 & .00 & .00 & .00 & .00 & .00 & .00 & .00 & -- \\
\hline 11 & .00 & .00 & .00 & .00 & .00 & .00 & .00 & .00 & .01 & .00 & .00 & .00 & -- \\
\hline 12 & .00 & .00 & .00 & .00 & .00 & .00 & .00 & .00 & .26 & .00 & .00 & .00 & -- \\
\hline 13 & .00 & .00 & .00 & .00 & .00 & .00 & .00 & .00 & .00 & .00 & .00 & .00 & -- \\
\hline 14 & .00 & .00 & .00 & .00 & .00 & .00 & .00 & .00 & .00 & .00 & .00 & .00 & -- \\
\hline 15 & .00 & .00 & .00 & .00 & .00 & .00 & .00 & .00 & .00 & .00 & .00 & .00 & -- \\
\hline 16 & .00 & .00 & .00 & .00 & .00 & .00 & .00 & .00 & .00 & .00 & .00 & .00 & -- \\
\hline 17 & .00 & .00 & .00 & .00 & .00 & .00 & .00 & .00 & .00 & .00 & .00 & .00 & -- \\
\hline 23 & .00 & .00 & .00 & .00 & .00 & .00 & .00 & .00 & .00 & .00 & .00 & .00 & -- \\
\hline 24 & .00 & .00 & .00 & .00 & .00 & .00 & .00 & .00 & .00 & .00 & .00 & .00 & -- \\
\hline 25 & .00 & .00 & .00 & .00 & .00 & .00 & .00 & .00 & .00 & .00 & .00 & .00 & -- \\
\hline 26 & .00 & .00 & .00 & .00 & .00 & .00 & .00 & .00 & .00 & .00 & .00 & .00 & -- \\
\hline 27 & .00 & .00 & .00 & .00 & .00 & .00 & .00 & .00 & .00 & .00 & .00 & .00 & -- \\
\hline 28 & .00 & .00 & .00 & .00 & .00 & .00 & .00 & .00 & .00 & .00 & .00 & .00 & -- \\
\hline 29 & .00 & -- & .00 & .00 & .00 & .00 & .00 & .00 & .00 & .00 & .00 & .00 & -- \\
\hline 30 & .00 & -- & .00 & .00 & .00 & .00 & .00 & .00 & .00 & .00 & .00 & .00 & -- \\
\hline 31 & .00 & -- & .00 & -- & .00 & -- & .00 & .00 & -- & .00 & -- & .00 & -- \\
\hline Total & .00 & 3.5 & .00 & .00 & .00 & .32 & 3.6 & .00 & 1.6 & .00 & .00 & .00 & 9.0 \\
\hline Mean & .00 & .12 & .00 & .00 & .00 & .01 & .12 & .00 & .05 & .00 & .00 & .00 & 0.02 \\
\hline Maximum & .00 & 3.4 & .00 & .00 & .00 & .17 & 2.8 & .00 & .79 & .00 & .00 & .00 & 3.4 \\
\hline Minimum & .00 & .00 & .00 & .00 & .00 & .00 & .00 & .00 & .00 & .00 & .00 & .00 & .00 \\
\hline
\end{tabular}


Appendix 2. Daily mean streamflow during 2002-10 at site $L_{\text {SW }}$ (U.S. Geological Survey streamflow-gaging station 08180942 Laurel Canyon Creek near Helotes, Texas), Government Canyon State Natural Area, Bexar County, Tex.-Continued.

[-- , not collected or calculated or not applicable; e, estimated]

2004 Streamflow

(cubic feet per second)

\begin{tabular}{|c|c|c|c|c|c|c|c|c|c|c|c|c|c|}
\hline \multirow{2}{*}{ Day } & \multicolumn{13}{|c|}{ (cubic teet per secona) } \\
\hline & Jan. & Feb. & Mar. & Apr. & May & June & July & Aug. & Sept. & Oct. & Nov. & Dec. & $\begin{array}{l}\text { Annual } \\
\text { summary }\end{array}$ \\
\hline 1 & 0.00 & 0.00 & 0.00 & 0.00 & 0.08 & 0.00 & 0.01 & 0.00 & 0.00 & 0.00 & 0.37 & 0.00 & -- \\
\hline 2 & .00 & .00 & .00 & .07 & .01 & .00 & .00 & .00 & .00 & e. 00 & .01 & .00 & -- \\
\hline 3 & .00 & .00 & .00 & .00 & .00 & .00 & .00 & .00 & .00 & e. 00 & .00 & .00 & -- \\
\hline 4 & .00 & .00 & .00 & .06 & .00 & .00 & .00 & .00 & .01 & .00 & .00 & .00 & -- \\
\hline 5 & .00 & .00 & .00 & .07 & .00 & .00 & .00 & .00 & .00 & .00 & .00 & .00 & -- \\
\hline 6 & .00 & .00 & .00 & .00 & .00 & .00 & .00 & .00 & .00 & .00 & .00 & .00 & -- \\
\hline 7 & .00 & .00 & .00 & .00 & .19 & .00 & .00 & .00 & .00 & .00 & .00 & .00 & -- \\
\hline 8 & .00 & .00 & .00 & .00 & .08 & .00 & .00 & .00 & .00 & .00 & .00 & .00 & -- \\
\hline 9 & .00 & .00 & .00 & .00 & .03 & 13 & .00 & .00 & .00 & .00 & .00 & .00 & -- \\
\hline 10 & .00 & .00 & .00 & .00 & .00 & 4.7 & .00 & .00 & .00 & .00 & .00 & .00 & -- \\
\hline 11 & .00 & .00 & .00 & .00 & .00 & .00 & .00 & .00 & .00 & .00 & .00 & .00 & -- \\
\hline 12 & .00 & .00 & .00 & .00 & .00 & .00 & .00 & .00 & .00 & .00 & .00 & .00 & -- \\
\hline 13 & .00 & .00 & .00 & .00 & .00 & .00 & .00 & .00 & .00 & .00 & .00 & .00 & -- \\
\hline 14 & .00 & .00 & .01 & .00 & .00 & .00 & .00 & .00 & .00 & .00 & .03 & .00 & -- \\
\hline 15 & .00 & .00 & .01 & .00 & .00 & .00 & .00 & .00 & .00 & .00 & .03 & .00 & -- \\
\hline 16 & .02 & .00 & .00 & .00 & .00 & .00 & .00 & .00 & .00 & .00 & 9.0 & .00 & -- \\
\hline 17 & .00 & .00 & .00 & .00 & .00 & .00 & .00 & .00 & .00 & .00 & 8.5 & .00 & -- \\
\hline 18 & .00 & .00 & .00 & .00 & .00 & .00 & .00 & .00 & .00 & .00 & .12 & .00 & -- \\
\hline 19 & .00 & .00 & .00 & .00 & .00 & .00 & .00 & .00 & .00 & .00 & .01 & .00 & -- \\
\hline 20 & .00 & .00 & .00 & .00 & .00 & .00 & .00 & .00 & .00 & .00 & .00 & .00 & -- \\
\hline 21 & .00 & .00 & .00 & .00 & .00 & .00 & .00 & .00 & .00 & .00 & .00 & .00 & -- \\
\hline 22 & .00 & .00 & .00 & .00 & .00 & .00 & .00 & .01 & .00 & .00 & 55 & .00 & -- \\
\hline 23 & .00 & .00 & .00 & .00 & .00 & .00 & .00 & 2.8 & .00 & .00 & .23 & .00 & -- \\
\hline 24 & .00 & .00 & .00 & 1.1 & .00 & .00 & .00 & .01 & .00 & .09 & .04 & .00 & -- \\
\hline 25 & .00 & .00 & .00 & .02 & .00 & .04 & .00 & .00 & .00 & .00 & .01 & .00 & -- \\
\hline 26 & .00 & .00 & .00 & .00 & .00 & .00 & .00 & .00 & .00 & .00 & .00 & .00 & -- \\
\hline 27 & .00 & .00 & .00 & .00 & .00 & .07 & .00 & .00 & .00 & .00 & .00 & .00 & -- \\
\hline 28 & .00 & .00 & .00 & .00 & .00 & 12 & .00 & .00 & .00 & .00 & .00 & .00 & -- \\
\hline 29 & .00 & .00 & .00 & .00 & .00 & 1.6 & .00 & .00 & .00 & .00 & .00 & .00 & -- \\
\hline 30 & .00 & -- & .00 & .00 & .00 & .15 & .98 & .00 & .00 & .00 & .00 & .00 & -- \\
\hline 31 & .00 & -- & .00 & -- & .00 & -- & .01 & .00 & -- & .00 & -- & .00 & -- \\
\hline Total & .02 & .00 & .02 & 1.3 & .39 & 32 & 1.0 & 2.8 & .01 & .09 & 73 & .00 & 111 \\
\hline Mean & .00 & .00 & .00 & .04 & .01 & 1.1 & .03 & .09 & .00 & .00 & 2.4 & .00 & .30 \\
\hline Maximum & .02 & .00 & .01 & 1.1 & .19 & 13 & .98 & 2.8 & .01 & .09 & 55 & .00 & 55 \\
\hline Minimum & .00 & .00 & .00 & .00 & .00 & .00 & .00 & .00 & .00 & .00 & .00 & .00 & .00 \\
\hline
\end{tabular}


Appendix 2. Daily mean streamflow during 2002-10 at site $\mathrm{LC}_{\mathrm{SW}}$ (U.S. Geological Survey streamflow-gaging station 08180942 Laurel Canyon Creek near Helotes, Texas), Government Canyon State Natural Area, Bexar County, Tex.-Continued.

[-- , not collected or calculated or not applicable; e, estimated]

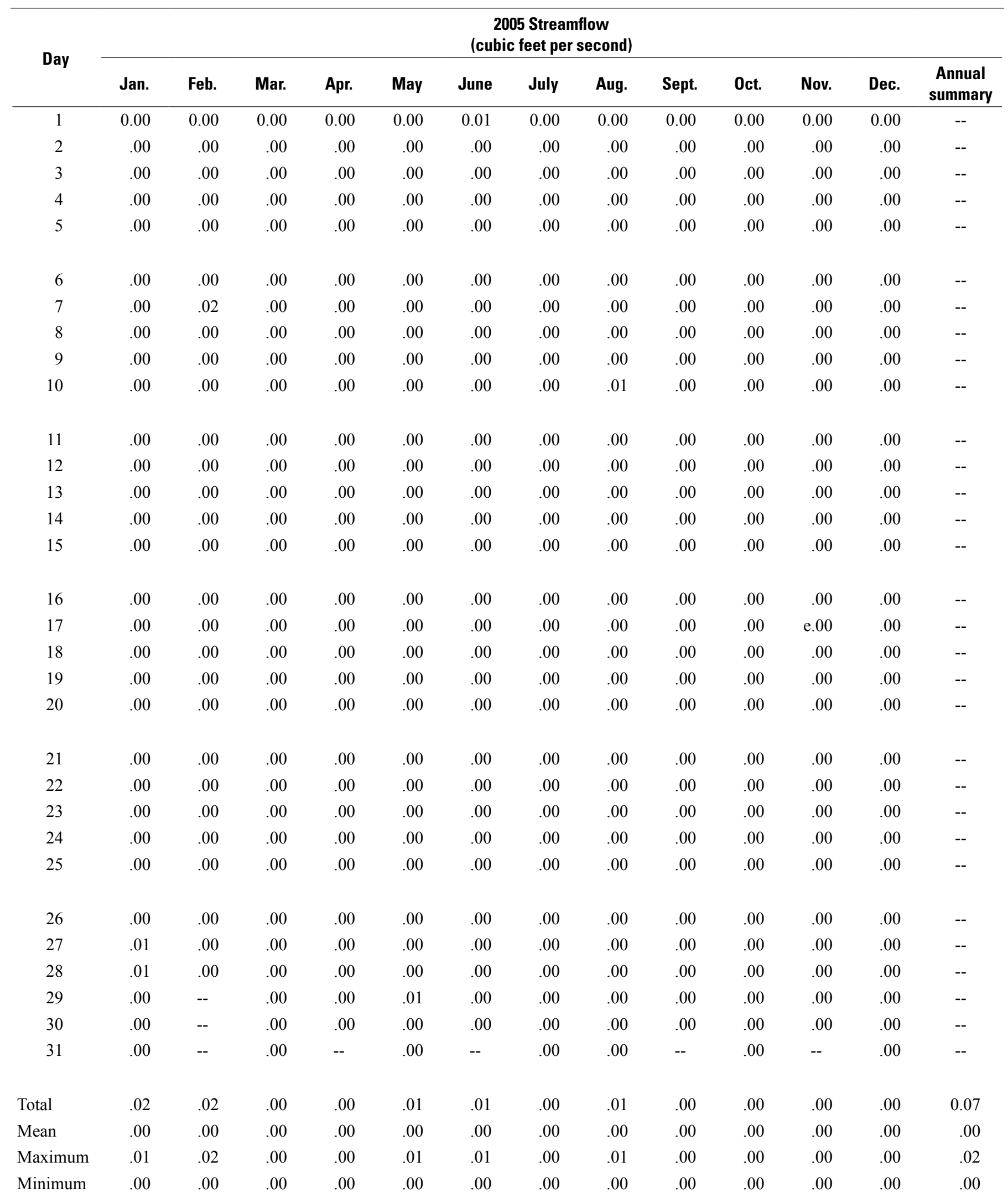


Appendix 2. Daily mean streamflow during 2002-10 at site LC $_{S W}$ (U.S. Geological Survey streamflow-gaging station 08180942 Laurel Canyon Creek near Helotes, Texas), Government Canyon State Natural Area, Bexar County, Tex.-Continued.

[-- , not collected or calculated or not applicable; e, estimated]

2006 Streamflow

(cubic feet per second)

\begin{tabular}{|c|c|c|c|c|c|c|c|c|c|c|c|c|c|}
\hline \multirow{2}{*}{ Day } & \multicolumn{13}{|c|}{ fcubic teet pe } \\
\hline & Jan. & Feb. & Mar. & Apr. & May & June & July & Aug. & Sept. & Oct. & Nov. & Dec. & $\begin{array}{c}\text { Annual } \\
\text { summary }\end{array}$ \\
\hline 1 & 0.00 & 0.00 & 0.00 & 0.00 & 0.00 & 0.00 & 0.00 & 0.00 & 0.00 & 0.00 & 0.00 & 0.00 & -- \\
\hline 2 & .00 & .00 & .00 & .00 & .00 & .00 & .01 & .00 & .00 & .00 & .00 & .00 & -- \\
\hline 3 & .00 & .00 & .00 & .00 & .00 & .00 & .00 & .00 & .00 & .00 & .00 & .00 & -- \\
\hline 4 & .00 & .00 & .00 & .00 & .01 & .00 & .00 & .00 & .00 & .00 & .00 & .00 & -- \\
\hline 5 & .00 & .00 & .00 & .00 & .10 & .00 & .00 & .00 & .00 & .00 & .00 & .00 & -- \\
\hline 6 & .00 & .00 & .00 & .00 & .05 & .00 & .00 & .00 & .00 & .00 & .00 & .00 & -- \\
\hline 7 & .00 & .00 & .00 & .00 & .00 & .00 & .00 & .00 & .00 & .00 & .00 & .00 & -- \\
\hline 8 & .00 & .00 & .00 & .00 & .00 & .00 & .00 & .00 & .00 & .00 & .00 & .00 & -- \\
\hline 9 & .00 & .00 & .00 & .00 & .00 & .00 & .00 & .00 & .00 & .00 & .00 & .00 & -- \\
\hline 10 & .00 & .00 & .00 & .00 & .00 & .00 & .00 & .00 & .00 & .00 & .00 & .00 & -- \\
\hline 11 & .00 & .00 & .00 & .00 & .00 & .00 & .00 & .00 & .00 & .00 & .00 & .00 & -- \\
\hline 12 & .00 & .00 & .00 & .00 & .00 & .00 & .00 & .00 & .00 & .00 & .00 & .00 & -- \\
\hline 13 & .00 & .00 & .00 & .00 & .00 & .00 & .00 & .00 & .00 & .00 & .00 & .00 & -- \\
\hline 14 & .00 & .00 & .00 & .00 & .00 & .00 & .00 & .00 & .00 & .00 & .00 & .00 & -- \\
\hline 15 & .00 & .00 & .00 & .00 & .00 & .00 & .00 & .00 & .00 & .00 & .00 & .00 & -- \\
\hline 16 & .00 & .00 & .00 & .00 & .00 & .00 & .00 & .00 & .00 & .00 & .00 & .00 & -- \\
\hline 17 & .00 & .00 & .00 & .00 & .00 & .00 & .00 & .00 & .00 & .00 & .00 & .00 & -- \\
\hline 18 & .00 & .00 & .00 & .00 & .00 & .00 & .00 & .00 & .00 & .00 & .00 & .00 & -- \\
\hline 19 & .00 & .00 & .00 & .00 & .00 & .00 & .00 & .00 & .00 & .00 & .00 & .00 & -- \\
\hline 20 & .00 & .00 & .03 & .00 & .00 & .00 & .00 & .00 & .00 & .00 & .00 & .00 & -- \\
\hline 21 & .00 & .00 & .00 & .00 & .00 & .00 & .00 & .00 & .00 & .00 & .00 & .00 & -- \\
\hline 22 & .00 & .00 & .00 & .00 & .00 & .00 & .00 & .00 & .00 & .00 & .00 & .00 & -- \\
\hline 23 & .00 & .00 & .00 & .00 & .00 & .00 & .00 & .00 & .00 & .00 & .00 & .00 & -- \\
\hline 24 & .00 & .00 & .00 & .00 & .00 & .00 & .00 & .00 & .00 & .00 & .00 & .00 & -- \\
\hline 25 & .00 & .00 & .00 & .00 & .00 & .00 & .00 & .00 & .00 & .00 & .00 & .00 & -- \\
\hline 26 & .00 & .00 & .00 & .00 & .00 & .00 & .00 & .00 & .00 & .00 & .00 & .00 & -- \\
\hline 27 & .00 & .00 & .00 & .00 & .00 & .00 & .00 & .00 & .00 & .00 & .00 & .00 & -- \\
\hline 28 & .00 & .00 & .00 & .00 & .00 & .00 & .00 & .00 & .00 & .00 & .00 & .00 & -- \\
\hline 29 & .00 & -- & .00 & .00 & .00 & .00 & .00 & .00 & .00 & .00 & .00 & .00 & -- \\
\hline 30 & .00 & -- & .00 & .00 & .00 & .00 & .00 & .00 & .00 & .00 & .00 & .00 & -- \\
\hline 31 & .00 & -- & .00 & -- & .00 & -- & .00 & .00 & -- & .00 & -- & .00 & -- \\
\hline Total & .00 & .00 & .03 & .00 & .16 & .00 & .01 & .00 & .00 & .00 & .00 & .00 & 0.20 \\
\hline Mean & .00 & .00 & .00 & .00 & .01 & .00 & .00 & .00 & .00 & .00 & .00 & .00 & .00 \\
\hline Maximum & .00 & .00 & .03 & .00 & .10 & .00 & .01 & .00 & .00 & .00 & .00 & .00 & .10 \\
\hline Minimum & .00 & .00 & .00 & .00 & .00 & .00 & .00 & .00 & .00 & .00 & .00 & .00 & .00 \\
\hline
\end{tabular}


Appendix 2. Daily mean streamflow during 2002-10 at site $\mathrm{LC}_{\mathrm{SW}}$ (U.S. Geological Survey streamflow-gaging station 08180942 Laurel Canyon Creek near Helotes, Texas), Government Canyon State Natural Area, Bexar County, Tex.-Continued.

$[--$, not collected or calculated or not applicable; e, estimated]

2007 Streamflow

(cubic feet per second)

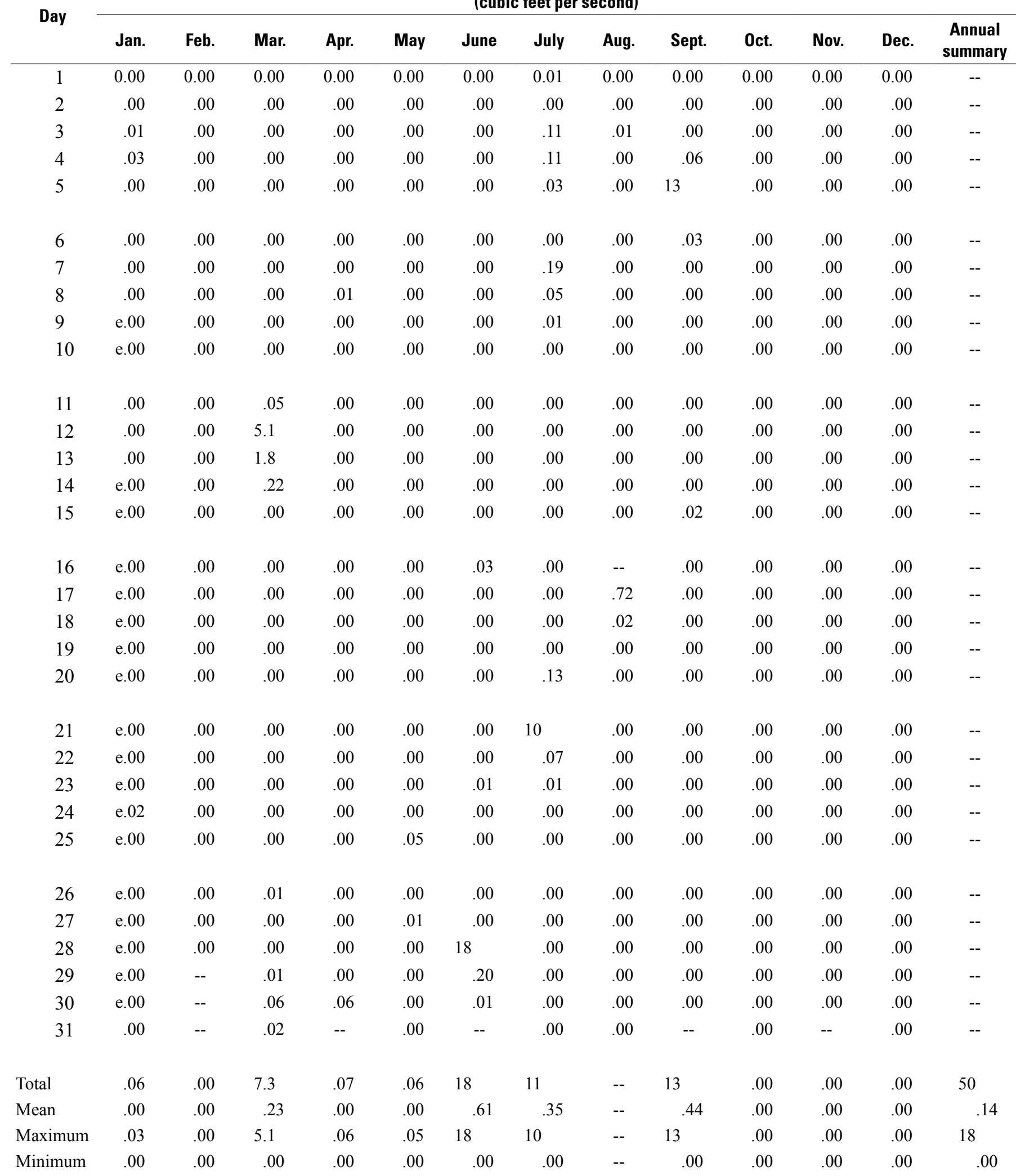


Appendix 2. Daily mean streamflow during 2002-10 at site LC $_{S W}$ (U.S. Geological Survey streamflow-gaging station 08180942 Laurel Canyon Creek near Helotes, Texas), Government Canyon State Natural Area, Bexar County, Tex.-Continued.

[-- , not collected or calculated or not applicable; e, estimated]

2008 Streamflow

(cubic feet per second)

\begin{tabular}{|c|c|c|c|c|c|c|c|c|c|c|c|c|c|}
\hline \multirow{2}{*}{ Day } & \multicolumn{13}{|c|}{ (cubic teet per second) } \\
\hline & Jan. & Feb. & Mar. & Apr. & May & June & July & Aug. & Sept. & Oct. & Nov. & Dec. & $\begin{array}{c}\text { Annual } \\
\text { summary }\end{array}$ \\
\hline 1 & 0.00 & 0.00 & 0.00 & 0.00 & 0.00 & 0.00 & 0.00 & 0.00 & 0.00 & 0.00 & 0.00 & 0.00 & -- \\
\hline 2 & .00 & .00 & .00 & .00 & .00 & .00 & .00 & .00 & .00 & .00 & .00 & .00 & -- \\
\hline 3 & .00 & .00 & .00 & .00 & .00 & .00 & .00 & .00 & .00 & .00 & .00 & .00 & -- \\
\hline 4 & .00 & .00 & .00 & .00 & .00 & .00 & .00 & .00 & .00 & .00 & .00 & .00 & -- \\
\hline 5 & .00 & .00 & .00 & .00 & .00 & .00 & .00 & .00 & .00 & .00 & .00 & .00 & -- \\
\hline 6 & .00 & .00 & .00 & .00 & .00 & .00 & .00 & .00 & .00 & .00 & .00 & .00 & -- \\
\hline 7 & .00 & .00 & .00 & .00 & .00 & .00 & .00 & .00 & .00 & .00 & .00 & .00 & -- \\
\hline 8 & .00 & .00 & .00 & .00 & .00 & .00 & .00 & .00 & .00 & .00 & .00 & .00 & -- \\
\hline 9 & .00 & .00 & .00 & .00 & .00 & .00 & .00 & .00 & .00 & .00 & .00 & .00 & -- \\
\hline 10 & .00 & .00 & .00 & .00 & .00 & .00 & .00 & .00 & .00 & .00 & .00 & .00 & -- \\
\hline 11 & .00 & .00 & .00 & .00 & .00 & .00 & .00 & .00 & .00 & .00 & .00 & .00 & -- \\
\hline 12 & .00 & .00 & .00 & .00 & .00 & .00 & .00 & .01 & .00 & .00 & .00 & .00 & -- \\
\hline 13 & .00 & .00 & .00 & .00 & .00 & .00 & .00 & .00 & .00 & .00 & .00 & .00 & -- \\
\hline 14 & .00 & .00 & .00 & .00 & .00 & .00 & .00 & .00 & .00 & .00 & .00 & .00 & -- \\
\hline 15 & .00 & .00 & .00 & .00 & .00 & .00 & .00 & .00 & .00 & .00 & .00 & .00 & -- \\
\hline 16 & .00 & .00 & .00 & .00 & .00 & .00 & .00 & .00 & .00 & .00 & .00 & .00 & -- \\
\hline 17 & .00 & .00 & .00 & .00 & .00 & .00 & .00 & .00 & .00 & .00 & .00 & .00 & -- \\
\hline 18 & .00 & .00 & .00 & .00 & .00 & .00 & .00 & .00 & .00 & .00 & .00 & .00 & -- \\
\hline 19 & .00 & .00 & .01 & .00 & .00 & .00 & .00 & .00 & .00 & .00 & .00 & .00 & -- \\
\hline 20 & .00 & .00 & .00 & .00 & .00 & .00 & .00 & .00 & .00 & .00 & .00 & .00 & -- \\
\hline 21 & .00 & .00 & .00 & .00 & .00 & .00 & .00 & .00 & .00 & .00 & .00 & .00 & -- \\
\hline 22 & .00 & .00 & .00 & .00 & .00 & .00 & .00 & .00 & .00 & .00 & .00 & .00 & -- \\
\hline 23 & .00 & .00 & .00 & .00 & .00 & .00 & .00 & .00 & .00 & .00 & .00 & .00 & -- \\
\hline 24 & .00 & .00 & .00 & .00 & .00 & .00 & .05 & .03 & .00 & .00 & .00 & .00 & -- \\
\hline 25 & .00 & .00 & .00 & .00 & .00 & .00 & .00 & .00 & .00 & .00 & .00 & .00 & -- \\
\hline 26 & .00 & .00 & .00 & .00 & .00 & .00 & .00 & .00 & .00 & .00 & .00 & .00 & -- \\
\hline 27 & .00 & .00 & .00 & .00 & .00 & .00 & .00 & .00 & .00 & .00 & .00 & .00 & -- \\
\hline 28 & .00 & .00 & .00 & .00 & .00 & .00 & .00 & .00 & .00 & .00 & .00 & .00 & -- \\
\hline 29 & .00 & .00 & .00 & .00 & .00 & .00 & .00 & .00 & .00 & .00 & .00 & .00 & -- \\
\hline 30 & .00 & -- & .00 & .00 & .00 & .00 & .00 & .00 & .00 & .00 & .00 & .00 & -- \\
\hline 31 & .00 & -- & .00 & -- & .00 & -- & .00 & .00 & -- & .00 & -- & .00 & -- \\
\hline Total & .00 & .00 & .01 & .00 & .00 & .00 & .05 & .04 & .00 & .00 & .00 & .00 & 0.10 \\
\hline Mean & .00 & .00 & .00 & .00 & .00 & .00 & .00 & .00 & .00 & .00 & .00 & .00 & .00 \\
\hline Maximum & .00 & .00 & .01 & .00 & .00 & .00 & .05 & .03 & .00 & .00 & .00 & .00 & .05 \\
\hline Minimum & .00 & .00 & .00 & .00 & .00 & .00 & .00 & .00 & .00 & .00 & .00 & .00 & .00 \\
\hline
\end{tabular}


Appendix 2. Daily mean streamflow during 2002-10 at site $\mathrm{LC}_{\mathrm{SW}}$ (U.S. Geological Survey streamflow-gaging station 08180942 Laurel Canyon Creek near Helotes, Texas), Government Canyon State Natural Area, Bexar County, Tex.-Continued.

$[--$, not collected or calculated or not applicable; e, estimated]

2009 Streamflow

(cubic feet per second)

\begin{tabular}{|c|c|c|c|c|c|c|c|c|c|c|c|c|c|}
\hline \multirow{2}{*}{ Day } & \multicolumn{13}{|c|}{ (cubic teet per second) } \\
\hline & Jan. & Feb. & Mar. & Apr. & May & June & July & Aug. & Sept. & Oct. & Nov. & Dec. & $\begin{array}{l}\text { Annual } \\
\text { summary }\end{array}$ \\
\hline 1 & 0.00 & 0.00 & 0.00 & 0.00 & 0.00 & 0.00 & 0.00 & 0.00 & 0.00 & 0.00 & 0.00 & 0.00 & -- \\
\hline 3 & .00 & .00 & .00 & .00 & .00 & .00 & .00 & .00 & .00 & .00 & .00 & .00 & -- \\
\hline 4 & .00 & .00 & .00 & .00 & .00 & .00 & .00 & .00 & .00 & 5.5 & .00 & .00 & -- \\
\hline 6 & .00 & .00 & .00 & .00 & .00 & .00 & .00 & .00 & .00 & .00 & .00 & .00 & -- \\
\hline 7 & .00 & .00 & .00 & .00 & .00 & .00 & .00 & .00 & .00 & .00 & .00 & .00 & -- \\
\hline 8 & .00 & .00 & .00 & .00 & .00 & .00 & .00 & .00 & .00 & .00 & .01 & .00 & -- \\
\hline 9 & .00 & .00 & .00 & .00 & .00 & .00 & .00 & .00 & .00 & .28 & .00 & .00 & -- \\
\hline 12 & .00 & .00 & .01 & .00 & .00 & .00 & .00 & .00 & .00 & .00 & .00 & .00 & -- \\
\hline 13 & .00 & .00 & .00 & .00 & .00 & .00 & .00 & .00 & .00 & .00 & .00 & .00 & -- \\
\hline 14 & .00 & .00 & .00 & .00 & .00 & .00 & .00 & .00 & .00 & .00 & .00 & .00 & -- \\
\hline 15 & .00 & .00 & .00 & .00 & .00 & .00 & .00 & .00 & .00 & .00 & .00 & .00 & -- \\
\hline 16 & .00 & .00 & .00 & .00 & .01 & .00 & .00 & .00 & .00 & .00 & .00 & .00 & -- \\
\hline 17 & .00 & .00 & .00 & .00 & .00 & .00 & .00 & .00 & .00 & .00 & .00 & .00 & -- \\
\hline 18 & .00 & .00 & .00 & .00 & .00 & .00 & .00 & .00 & .00 & .00 & .00 & .00 & -- \\
\hline 19 & .00 & .00 & .00 & .00 & .00 & .00 & .00 & .00 & .00 & .00 & .00 & .00 & -- \\
\hline 25 & .00 & .00 & .00 & .00 & .00 & .00 & .00 & .00 & .00 & .00 & .00 & .00 & -- \\
\hline 26 & .00 & .00 & .00 & .00 & .00 & .00 & .00 & .00 & .00 & .10 & .00 & .00 & -- \\
\hline 27 & .00 & .00 & .00 & .00 & .00 & .00 & .00 & .00 & .00 & .02 & .00 & .00 & -- \\
\hline 28 & .00 & .00 & .00 & .00 & .00 & .00 & .00 & .00 & .00 & .00 & .00 & .00 & -- \\
\hline 29 & .00 & -- & .00 & .00 & .00 & .00 & .00 & .00 & .00 & .00 & .00 & .00 & -- \\
\hline 30 & .00 & -- & .00 & .00 & .00 & .00 & .00 & .00 & .00 & .00 & .00 & .00 & -- \\
\hline 31 & .00 & -- & .00 & -- & .00 & -- & .00 & .00 & -- & .00 & -- & .00 & -- \\
\hline Total & .00 & .00 & .01 & .00 & .01 & .00 & .00 & .00 & .05 & 6.8 & .01 & .00 & 6.9 \\
\hline Mean & .00 & .00 & .00 & .00 & .00 & .00 & .00 & .00 & .00 & .22 & .00 & .00 & .02 \\
\hline Maximum & .00 & .00 & .01 & .00 & .01 & .00 & .00 & .00 & .03 & 5.5 & .01 & .00 & 5.5 \\
\hline Minimum & .00 & .00 & .00 & .00 & .00 & .00 & .00 & .00 & .00 & .00 & .00 & .00 & .00 \\
\hline
\end{tabular}


Appendix 2. Daily mean streamflow during 2002-10 at site $\mathrm{LC}_{\mathrm{SW}}$ (U.S. Geological Survey streamflow-gaging station 08180942 Laurel Canyon Creek near Helotes, Texas), Government Canyon State Natural Area, Bexar County, Tex.-Continued.

[-- , not collected or calculated or not applicable; e, estimated]

2010 Streamflow

(cubic feet per second)

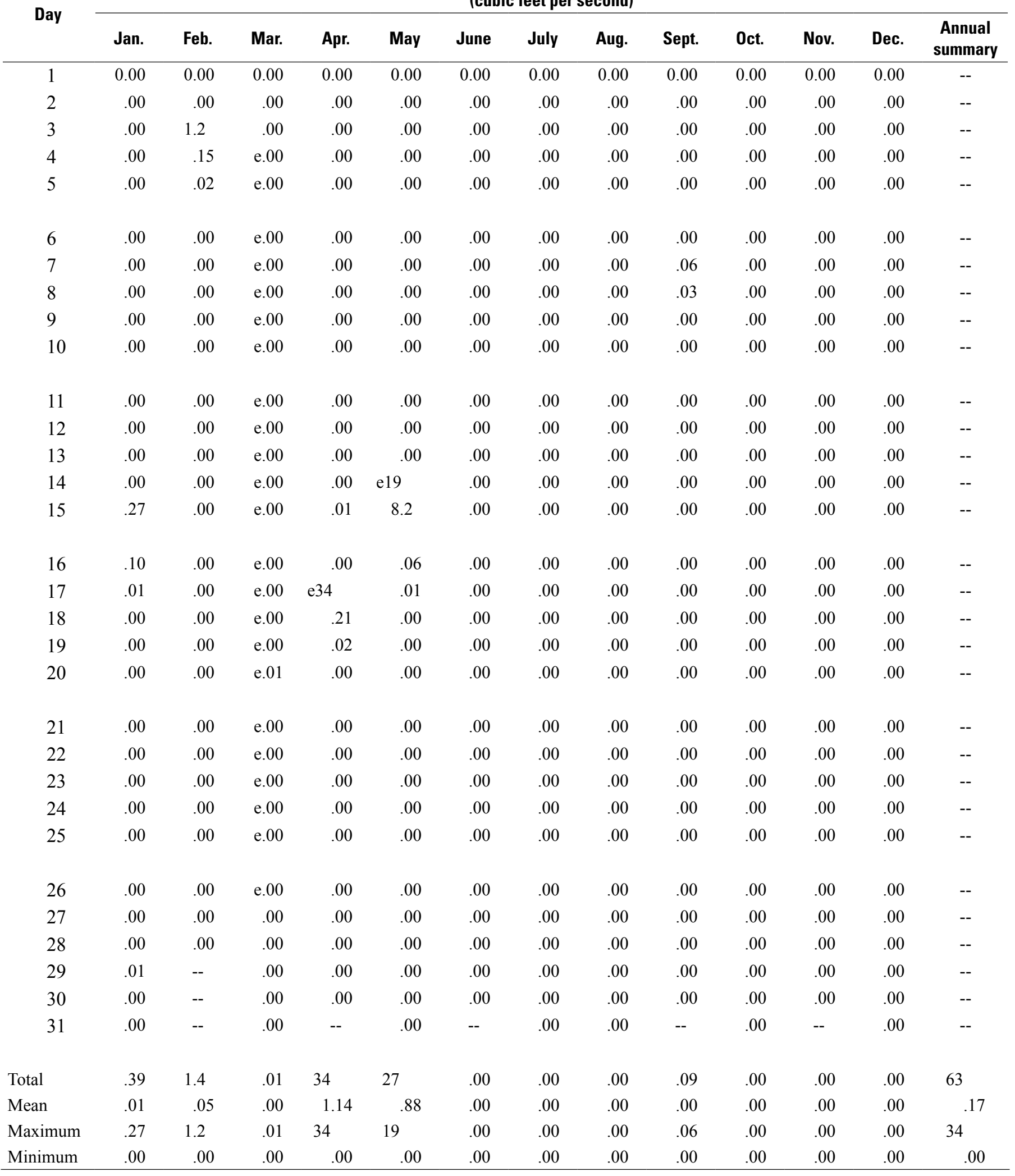




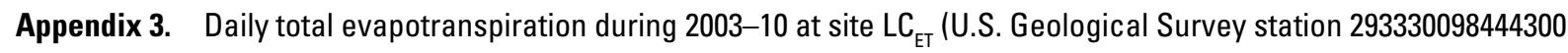
Evapotranspiration Laurel Canyon Watershed in the Government Canyon State Natural Area, near Helotes, Texas), Government Canyon State Natural Area, Bexar County, Tex.

[--, not applicable or not calculated]

2003 Evapotranspiration

\begin{tabular}{|c|c|c|c|c|c|c|c|c|c|c|c|c|}
\hline \multirow[t]{2}{*}{ Day } & \multicolumn{12}{|c|}{ (millimeters/day) } \\
\hline & Jan. & Feb. & Mar. & Apr. & May & June & July & Aug. & Sept. & Oct. & Nov. & Dec. \\
\hline
\end{tabular}

$\begin{array}{ccccc}1 & -- & -- & -- & - \\ 2 & -- & -- & -- & - \\ 3 & -- & -- & -- & - \\ 4 & -- & -- & -- & - \\ 5 & -- & -- & -- & -\end{array}$

$\begin{array}{rrrrr}6 & -- & -- & -- & - \\ 7 & -- & -- & -- & - \\ 8 & -- & -- & -- & - \\ 9 & -- & -- & -- & - \\ 10 & -- & -- & -- & -\end{array}$

$\begin{array}{lllll}11 & -- & -- & -- & - \\ 12 & -- & -- & -- & - \\ 13 & -- & -- & -- & -- \\ 14 & -- & -- & -- & -- \\ 15 & -- & -- & -- & --\end{array}$

$\begin{array}{lllll}16 & -- & -- & -- & - \\ 17 & -- & -- & -- & - \\ 18 & -- & -- & -- & - \\ 19 & -- & -- & -- & - \\ 20 & -- & -- & -- & -\end{array}$

$\begin{array}{lllll}21 & -- & -- & -- & - \\ 22 & -- & -- & -- & - \\ 23 & -- & -- & -- & - \\ 24 & -- & -- & -- & - \\ 25 & -- & -- & -- & -\end{array}$

$\begin{array}{lllll}26 & -- & -- & -- & -- \\ 27 & -- & -- & -- & -- \\ 28 & -- & -- & -- \\ 29 & -- & -- & -- & - \\ 30 & -- & -- & --\end{array}$


Appendix 3. Daily total evapotranspiration during 2003-10 at site LC $C_{E T}$ (U.S. Geological Survey station 293330098444300 Evapotranspiration Laurel Canyon Watershed in the Government Canyon State Natural Area, near Helotes, Texas), Government Canyon State Natural Area, Bexar County, Tex.-Continued.

[--, not applicable or not calculated]

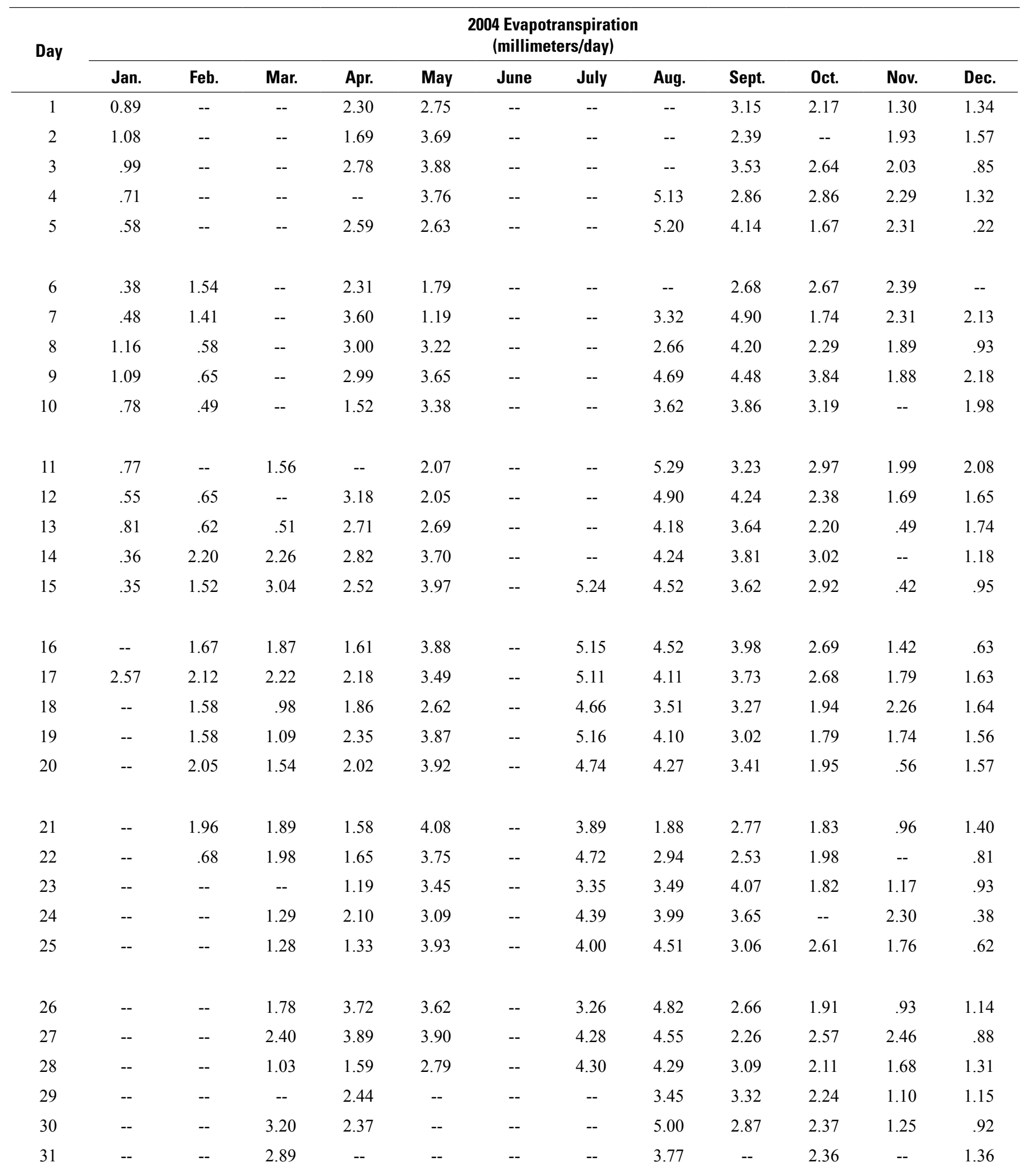




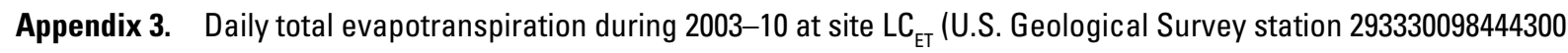
Evapotranspiration Laurel Canyon Watershed in the Government Canyon State Natural Area, near Helotes, Texas), Government Canyon State Natural Area, Bexar County, Tex.-Continued.

[--, not applicable or not calculated]

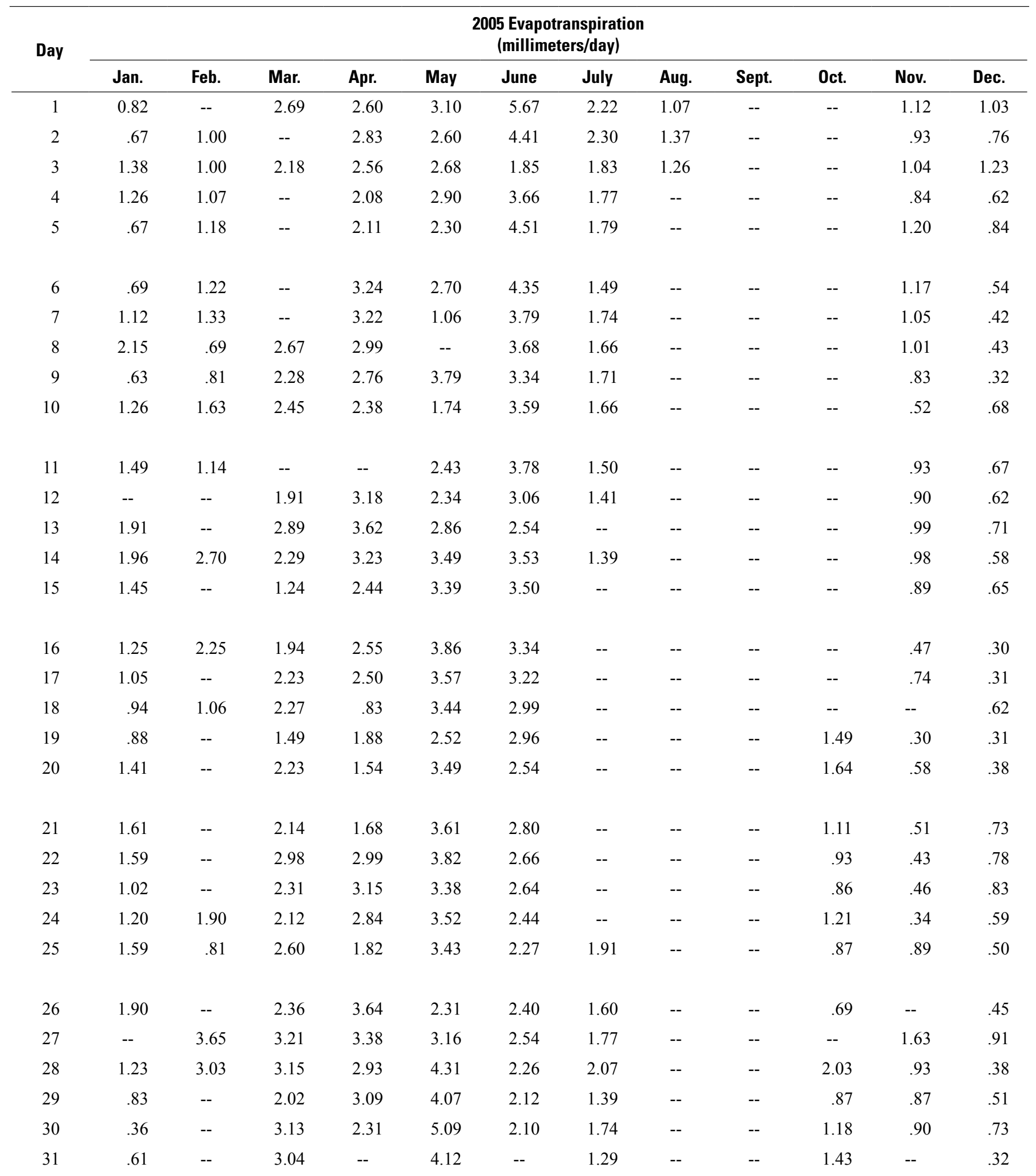


Appendix 3. Daily total evapotranspiration during 2003-10 at site LC ET $_{\text {(U.S. Geological Survey station } 293330098444300}$ Evapotranspiration Laurel Canyon Watershed in the Government Canyon State Natural Area, near Helotes, Texas), Government Canyon State Natural Area, Bexar County, Tex.-Continued.

[--, not applicable or not calculated]

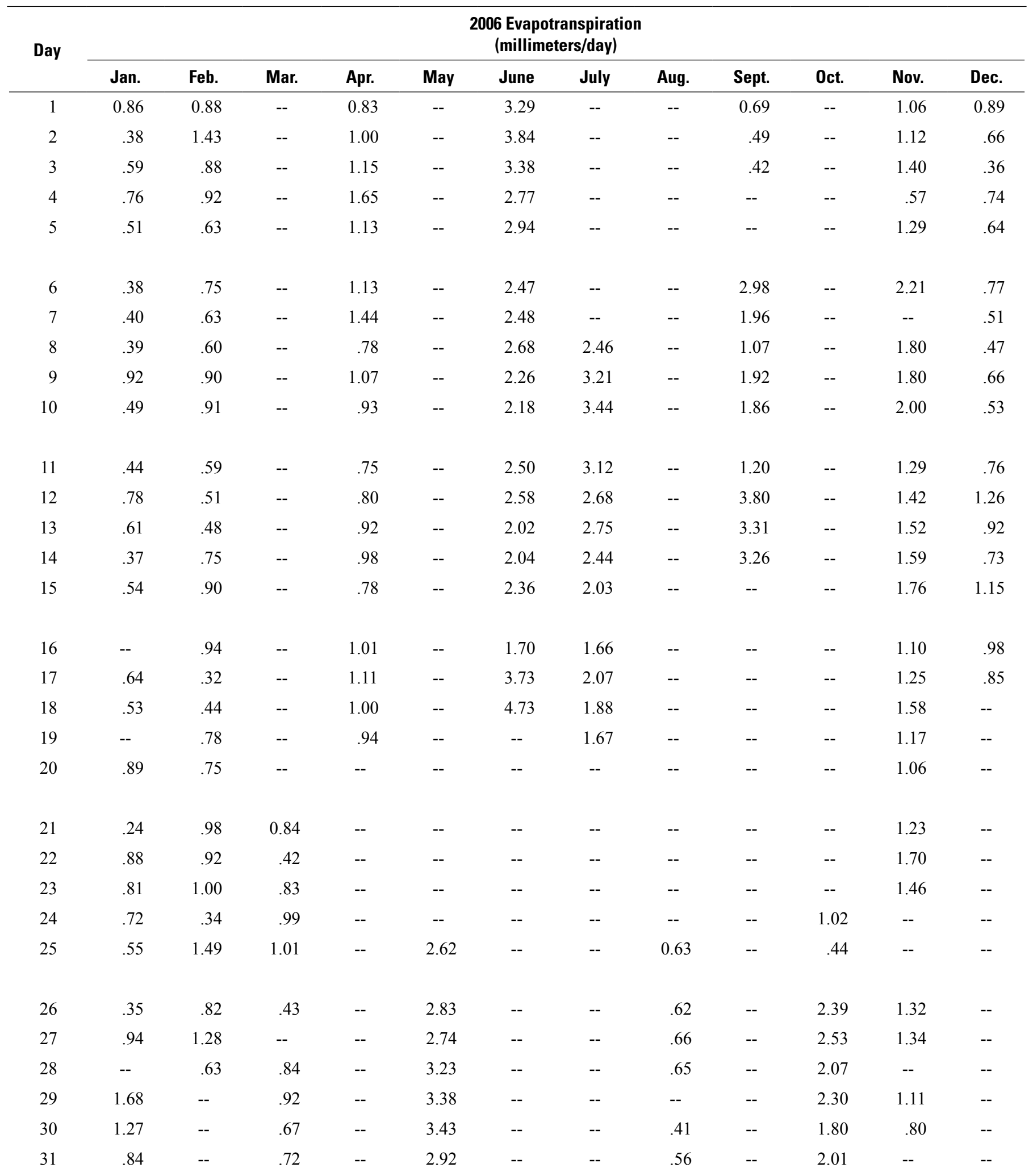




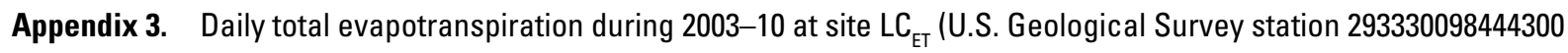
Evapotranspiration Laurel Canyon Watershed in the Government Canyon State Natural Area, near Helotes, Texas), Government Canyon State Natural Area, Bexar County, Tex.-Continued.

[--, not applicable or not calculated]

2007 Evapotranspiration

Day _ (millimeters/day)

\begin{tabular}{|c|c|c|c|c|c|c|c|c|c|c|c|c|}
\hline \multirow[t]{2}{*}{ Day } & \multicolumn{12}{|c|}{ (mıIIImeters/day) } \\
\hline & Jan. & Feb. & Mar. & Apr. & May & June & July & Aug. & Sept. & Oct. & Nov. & Dec. \\
\hline 1 & -- & -- & -- & -- & -- & -- & -- & 4.66 & -- & -- & 2.32 & -- \\
\hline 2 & -- & -- & -- & -- & -- & -- & -- & 3.91 & 2.92 & -- & 2.21 & -- \\
\hline 3 & -- & -- & -- & -- & -- & -- & -- & 3.90 & 2.45 & -- & 1.67 & -- \\
\hline 4 & -- & -- & -- & -- & -- & -- & -- & 5.13 & 1.65 & -- & 1.95 & -- \\
\hline 5 & -- & -- & -- & -- & -- & -- & -- & 4.25 & 2.97 & -- & 2.06 & -- \\
\hline 6 & -- & -- & -- & -- & -- & -- & -- & 4.40 & 3.92 & -- & 1.28 & -- \\
\hline 7 & -- & -- & -- & -- & -- & -- & -- & 4.19 & 4.11 & -- & 0.97 & -- \\
\hline 8 & -- & -- & -- & -- & -- & -- & -- & 4.50 & 3.89 & -- & 1.42 & -- \\
\hline 9 & -- & -- & -- & -- & -- & -- & -- & 4.77 & 4.05 & -- & 2.00 & -- \\
\hline 10 & -- & -- & -- & -- & -- & -- & -- & 4.86 & 3.50 & -- & 1.55 & -- \\
\hline
\end{tabular}

$\begin{array}{lllllllllllll}11 & -- & -- & -- & -- & -- & -- & - & 4.44 & -- & -- & 1.83 & -- \\ 12 & -- & -- & -- & -- & -- & -- & 4.64 & 4.14 & 4.33 & -- & 1.54 & -- \\ 13 & -- & -- & -- & -- & -- & -- & 4.90 & 4.52 & -- & -- & 1.60 & -- \\ 14 & -- & -- & -- & -- & -- & -- & 3.14 & 4.80 & -- & -- & 2.08 & - \\ 15 & -- & -- & -- & -- & -- & -- & 4.67 & 3.73 & -- & -- & 1.87 & --\end{array}$

\begin{tabular}{|c|c|c|c|c|c|c|c|c|c|c|c|c|}
\hline 16 & -- & -- & -- & -- & -- & -- & 4.48 & -- & -- & -- & 1.61 & -- \\
\hline 17 & -- & -- & -- & -- & -- & -- & 3.18 & 3.15 & -- & 3.11 & -- & -- \\
\hline 18 & -- & -- & -- & -- & -- & -- & 2.38 & 3.93 & -- & 2.96 & -- & -- \\
\hline 19 & -- & -- & -- & -- & -- & -- & 3.00 & 3.94 & -- & 3.25 & -- & -- \\
\hline 20 & -- & -- & -- & -- & -- & -- & 1.45 & 3.92 & -- & 2.46 & -- & -- \\
\hline 21 & -- & -- & -- & -- & -- & -- & 2.40 & 4.12 & -- & 2.36 & -- & -- \\
\hline 22 & -- & -- & -- & -- & -- & -- & 4.70 & 2.69 & -- & 2.04 & -- & 1.70 \\
\hline 23 & -- & -- & -- & -- & -- & -- & 4.48 & 4.32 & -- & 2.99 & -- & .78 \\
\hline 24 & -- & -- & -- & -- & -- & -- & 2.64 & 4.28 & -- & 2.89 & -- & -- \\
\hline 25 & -- & -- & -- & -- & -- & -- & 2.50 & 4.01 & -- & 2.31 & -- & -- \\
\hline 26 & -- & -- & -- & -- & -- & -- & 3.04 & 3.95 & -- & 2.64 & -- & -- \\
\hline 27 & -- & -- & -- & -- & -- & -- & 3.88 & 3.94 & -- & 2.53 & -- & -- \\
\hline 28 & -- & -- & -- & -- & -- & -- & 3.48 & 3.80 & -- & 2.27 & -- & -- \\
\hline 29 & -- & -- & -- & -- & -- & -- & 2.35 & 3.18 & -- & 2.12 & -- & -- \\
\hline 30 & -- & -- & -- & -- & -- & -- & 4.29 & 3.84 & -- & 2.35 & -- & -- \\
\hline 31 & -- & -- & -- & -- & -- & -- & 3.97 & -- & -- & 1.80 & -- & -- \\
\hline
\end{tabular}


Appendix 3. Daily total evapotranspiration during 2003-10 at site LC $C_{E T}$ (U.S. Geological Survey station 293330098444300 Evapotranspiration Laurel Canyon Watershed in the Government Canyon State Natural Area, near Helotes, Texas), Government Canyon State Natural Area, Bexar County, Tex.-Continued.

[--, not applicable or not calculated]

2008 Evapotranspiration (millimeters/day)

\begin{tabular}{|c|c|c|c|c|c|c|c|c|c|c|c|c|}
\hline \multirow[t]{2}{*}{ Day } & \multicolumn{12}{|c|}{ (millimeters/day) } \\
\hline & Jan. & Feb. & Mar. & Apr. & May & June & July & Aug. & Sept. & Oct. & Nov. & Dec. \\
\hline 1 & -- & -- & 1.28 & -- & 1.78 & 2.01 & -- & 2.85 & 3.69 & 1.79 & 1.66 & 0.43 \\
\hline 2 & -- & -- & .67 & -- & 1.88 & 1.83 & 1.82 & 2.76 & 3.61 & 1.37 & 1.54 & .43 \\
\hline 3 & -- & -- & 1.46 & -- & 1.73 & 2.13 & 1.71 & 3.37 & 3.40 & 1.70 & 1.12 & -- \\
\hline 4 & -- & -- & 1.13 & -- & 1.11 & 1.04 & 3.10 & 2.53 & 3.21 & 1.50 & 1.39 & .48 \\
\hline 5 & -- & -- & .93 & -- & 2.09 & 1.45 & 2.99 & 2.52 & 2.89 & 1.39 & 1.27 & .37 \\
\hline 6 & -- & -- & -- & -- & 1.28 & 1.86 & 2.52 & 3.90 & 2.92 & .93 & 1.29 & .46 \\
\hline 7 & -- & -- & 1.60 & -- & 1.83 & 2.05 & 1.62 & 3.01 & 3.19 & 1.65 & .78 & .45 \\
\hline 8 & -- & 0.98 & 1.10 & -- & 1.67 & 2.00 & 3.54 & 3.38 & 2.56 & 1.11 & .92 & .51 \\
\hline 9 & -- & 1.43 & .63 & -- & 1.82 & 1.98 & 2.77 & 2.96 & 2.30 & 1.32 & .96 & .85 \\
\hline 10 & -- & .99 & -- & -- & 1.92 & 1.98 & 2.60 & 2.90 & 2.28 & 1.39 & .90 & .88 \\
\hline 11 & -- & .48 & 3.03 & -- & 1.49 & 2.24 & 2.73 & 2.11 & 2.25 & 1.06 & .93 & .56 \\
\hline 12 & -- & 1.30 & 2.21 & -- & .86 & 1.99 & 2.88 & 2.02 & 2.70 & 1.00 & .84 & .63 \\
\hline 13 & -- & 1.34 & 1.63 & -- & 1.50 & 1.89 & 2.58 & 3.92 & 2.79 & 1.41 & .97 & .76 \\
\hline 14 & -- & 1.08 & 2.13 & -- & 2.85 & 2.10 & 2.44 & 3.99 & -- & 2.36 & 1.54 & .84 \\
\hline 15 & -- & .67 & 1.79 & -- & 3.68 & 1.91 & 2.05 & 3.62 & 2.04 & 2.19 & .77 & .31 \\
\hline 16 & -- & -- & -- & -- & 3.90 & 2.03 & 1.72 & 3.23 & 1.99 & 1.97 & .59 & .40 \\
\hline 17 & -- & 1.63 & -- & -- & 2.29 & 1.30 & 2.08 & 2.33 & 2.03 & 2.24 & .61 & .40 \\
\hline 18 & -- & 1.38 & -- & -- & 2.60 & 1.52 & 2.41 & 1.65 & 2.00 & 2.10 & .57 & .41 \\
\hline 19 & -- & 1.26 & -- & -- & 2.74 & 1.11 & 2.48 & 3.69 & 1.91 & 1.91 & .81 & -- \\
\hline 20 & -- & .88 & -- & -- & 2.85 & 2.33 & 1.99 & 5.07 & 1.85 & 2.12 & 1.53 & .61 \\
\hline 21 & -- & 1.45 & -- & -- & 2.56 & -- & 2.10 & 3.71 & 1.88 & 1.84 & .50 & .25 \\
\hline 22 & -- & 1.44 & -- & -- & 2.49 & 3.08 & 1.63 & 3.05 & 2.40 & 1.96 & .23 & .19 \\
\hline 23 & -- & 1.28 & -- & -- & 2.47 & 2.13 & -- & 2.17 & 2.34 & 1.17 & .85 & .56 \\
\hline 24 & -- & 1.48 & -- & 1.84 & 2.68 & 2.40 & 1.34 & 3.70 & 1.95 & 1.30 & 1.02 & .78 \\
\hline 25 & -- & 1.11 & -- & 1.29 & 2.05 & 2.10 & 3.40 & 4.39 & 1.94 & 1.78 & .50 & .56 \\
\hline 26 & -- & 1.14 & -- & 3.09 & 2.29 & 2.18 & 3.79 & 3.78 & 1.71 & 1.54 & .78 & .61 \\
\hline 27 & -- & .84 & -- & 1.82 & 2.05 & 2.32 & 3.94 & 3.61 & 1.53 & 1.24 & -- & .79 \\
\hline 28 & -- & 1.13 & -- & 1.91 & 2.20 & 2.09 & 4.04 & 3.70 & 1.50 & 1.05 & .74 & .26 \\
\hline 29 & -- & .80 & -- & 1.68 & 2.27 & 1.95 & 3.80 & 2.20 & 1.48 & 1.16 & .70 & .48 \\
\hline 30 & -- & -- & -- & 2.14 & 2.13 & -- & 2.53 & 3.34 & 1.30 & 1.61 & .57 & .41 \\
\hline 31 & -- & -- & -- & -- & 2.38 & -- & 3.65 & 3.88 & -- & 1.23 & -- & .47 \\
\hline
\end{tabular}




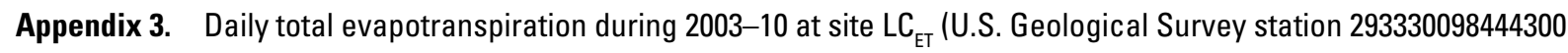
Evapotranspiration Laurel Canyon Watershed in the Government Canyon State Natural Area, near Helotes, Texas), Government Canyon State Natural Area, Bexar County, Tex.-Continued.

$[--$, not applicable or not calculated]

\begin{tabular}{|c|c|c|c|c|c|c|c|c|c|c|c|c|}
\hline \multirow[t]{2}{*}{ Day } & \multicolumn{12}{|c|}{$\begin{array}{l}2009 \text { Evapotranspiration } \\
\text { (millimeters/day) }\end{array}$} \\
\hline & Jan. & Feb. & Mar. & Apr. & May & June & July & Aug. & Sept. & Oct. & Nov. & Dec. \\
\hline 2 & .61 & .43 & .58 & -- & -- & 1.97 & 1.78 & 1.70 & 1.58 & 2.68 & 1.97 & 1.32 \\
\hline 3 & -- & .50 & .73 & -- & -- & 3.43 & 2.06 & 2.21 & 1.46 & .66 & 2.06 & .66 \\
\hline 5 & .43 & 1.07 & 1.07 & -- & -- & 1.49 & 1.80 & 1.81 & 1.11 & 1.99 & 1.92 & 1.13 \\
\hline 6 & 2.02 & .88 & .98 & -- & -- & 2.15 & 1.81 & 1.85 & 3.12 & 2.13 & 2.13 & .78 \\
\hline 7 & .77 & .54 & .61 & -- & 1.29 & 2.09 & 3.27 & 1.56 & 2.15 & 2.71 & 1.61 & .56 \\
\hline 11 & .51 & .58 & -- & -- & 2.09 & 1.77 & 2.59 & 1.80 & 1.15 & .93 & 2.10 & .26 \\
\hline 12 & .46 & .65 & -- & -- & 1.44 & 2.25 & 2.43 & -- & 2.67 & 1.23 & 1.79 & .62 \\
\hline 13 & .40 & .79 & .58 & -- & 1.76 & 2.03 & 2.11 & 2.00 & 1.90 & 1.86 & 2.18 & 2.06 \\
\hline 14 & .45 & .28 & 1.07 & -- & 1.08 & 2.24 & 2.38 & 2.30 & 1.92 & 2.85 & 1.78 & .47 \\
\hline 15 & .79 & .47 & 1.75 & -- & 1.79 & 1.92 & 2.40 & 2.04 & 3.16 & 3.16 & .92 & .72 \\
\hline 16 & .15 & .39 & 1.86 & -- & -- & 2.13 & 1.91 & 2.00 & 2.74 & 2.71 & 2.02 & .57 \\
\hline 22 & .40 & .46 & -- & -- & 2.14 & 1.50 & 2.97 & 1.64 & -- & 3.40 & 1.40 & .63 \\
\hline 23 & .68 & .60 & -- & -- & -- & 2.01 & 2.87 & 1.36 & -- & 2.33 & 1.46 & .94 \\
\hline 24 & .48 & 1.46 & -- & -- & 2.65 & 1.61 & 2.24 & 1.36 & -- & 2.21 & 2.18 & -- \\
\hline 25 & .34 & -- & -- & -- & 2.90 & 3.29 & 2.42 & 1.52 & 2.43 & 1.88 & 1.57 & .84 \\
\hline 26 & .79 & -- & -- & -- & 2.82 & 2.51 & 2.53 & 1.16 & 3.06 & -- & 1.64 & .90 \\
\hline 27 & .43 & -- & -- & -- & 1.91 & 2.55 & 2.46 & 1.09 & 3.14 & 2.29 & 1.51 & 1.23 \\
\hline 28 & .97 & -- & -- & -- & 2.39 & 2.19 & 2.27 & -- & 2.99 & 1.28 & .99 & .87 \\
\hline 29 & .69 & -- & -- & -- & 3.26 & 1.92 & 1.92 & 1.80 & 2.44 & 2.41 & .66 & -- \\
\hline 30 & .55 & -- & -- & -- & 2.37 & 1.81 & -- & 1.40 & 2.56 & 2.34 & -- & 1.12 \\
\hline 31 & .46 & -- & -- & -- & 2.22 & -- & 2.21 & .80 & -- & 2.10 & -- & 2.02 \\
\hline
\end{tabular}


Appendix 3. Daily total evapotranspiration during 2003-10 at site LC $_{E T}$ (U.S. Geological Survey station 293330098444300 Evapotranspiration Laurel Canyon Watershed in the Government Canyon State Natural Area, near Helotes, Texas), Government Canyon State Natural Area, Bexar County, Tex.-Continued.

[--, not applicable or not calculated]

2010 Evapotranspiration (millimeters/day)

\begin{tabular}{|c|c|c|c|c|c|c|c|c|c|c|c|c|}
\hline \multirow[t]{2}{*}{ Day } & \multicolumn{12}{|c|}{ (millimeters/day) } \\
\hline & Jan. & Feb. & Mar. & Apr. & May & June & July & Aug. & Sept. & Oct. & Nov. & Dec. \\
\hline 1 & 0.99 & -- & 2.06 & 2.53 & 3.17 & 3.71 & 1.80 & 4.27 & 2.36 & 3.24 & 2.03 & 0.99 \\
\hline 2 & 1.06 & -- & 1.93 & 2.70 & 3.82 & 2.88 & 3.08 & 4.43 & 2.21 & 3.34 & 2.18 & -- \\
\hline 3 & .53 & -- & 1.77 & 2.74 & 3.09 & 2.60 & 4.09 & 3.85 & 3.12 & 2.72 & 1.34 & -- \\
\hline 4 & 1.04 & -- & 2.20 & 1.86 & 3.03 & 4.56 & 3.91 & 4.09 & 2.49 & 2.67 & 1.56 & -- \\
\hline 5 & .79 & -- & .67 & 2.00 & 3.42 & 3.24 & 4.16 & 4.12 & 2.12 & 2.69 & 1.48 & -- \\
\hline 6 & .35 & -- & .97 & 2.48 & 3.32 & 2.92 & 4.55 & 3.77 & 2.30 & 2.76 & 1.44 & -- \\
\hline 7 & -- & -- & .30 & 2.33 & 3.35 & 4.41 & 4.24 & 3.44 & -- & 2.72 & 1.61 & -- \\
\hline 8 & -- & -- & .77 & 2.54 & 2.31 & 3.17 & 2.73 & 3.59 & 3.42 & 2.69 & 1.62 & .80 \\
\hline 9 & .50 & -- & 3.19 & 2.33 & 1.50 & 3.06 & -- & 3.50 & 3.73 & 3.26 & 2.01 & 1.39 \\
\hline 10 & -- & -- & -- & 2.14 & 2.32 & 4.04 & 5.54 & 3.55 & 3.08 & 2.45 & 1.95 & -- \\
\hline 11 & -- & -- & -- & .68 & 2.34 & 3.48 & 4.56 & 4.06 & 3.92 & 2.30 & 1.69 & -- \\
\hline 12 & -- & -- & -- & 2.31 & 3.06 & 3.55 & 4.66 & 3.46 & 3.77 & 2.47 & 1.70 & -- \\
\hline 13 & -- & -- & -- & .86 & 2.63 & 3.88 & 3.74 & 3.34 & 4.15 & 3.07 & 1.44 & -- \\
\hline 14 & -- & -- & -- & -- & -- & 4.10 & 4.11 & 2.94 & 3.61 & 2.47 & 1.15 & -- \\
\hline 15 & -- & -- & -- & -- & 4.05 & 4.11 & 4.58 & 2.97 & 3.85 & 2.58 & 1.69 & 1.49 \\
\hline 16 & -- & -- & -- & 2.75 & 2.48 & 3.83 & 4.55 & 2.93 & 4.25 & 2.28 & 1.34 & -- \\
\hline 17 & -- & -- & -- & -- & 3.61 & 4.18 & 4.66 & 2.61 & 3.22 & 2.28 & 1.40 & -- \\
\hline 18 & -- & -- & -- & 3.65 & 4.48 & 4.50 & 4.49 & 3.01 & 2.57 & 2.72 & 1.32 & .83 \\
\hline 19 & -- & 0.51 & -- & 1.87 & 2.72 & 3.37 & 4.34 & 2.57 & 2.02 & 1.94 & 1.05 & .73 \\
\hline 20 & -- & .77 & -- & 3.12 & 1.14 & 4.03 & 3.96 & 2.97 & 2.30 & 2.81 & 1.19 & -- \\
\hline 21 & -- & 2.63 & -- & 2.96 & 2.77 & 4.18 & 3.72 & 2.85 & 2.71 & 2.44 & -- & -- \\
\hline 22 & -- & 1.55 & -- & -- & 2.63 & 4.23 & 2.82 & 2.78 & 3.06 & 2.08 & -- & .78 \\
\hline 23 & -- & -- & -- & 3.84 & 3.09 & 3.94 & 4.68 & 2.25 & 3.47 & 2.08 & 1.04 & -- \\
\hline 24 & -- & 1.63 & -- & 3.51 & 2.50 & 4.07 & 4.57 & 2.33 & 3.28 & 1.94 & 1.41 & -- \\
\hline 25 & -- & 1.48 & -- & 3.37 & -- & 4.15 & 4.28 & 2.27 & 3.75 & 2.22 & 1.17 & -- \\
\hline 26 & -- & 1.64 & 1.93 & 3.32 & 3.55 & 3.72 & 3.63 & 1.98 & 3.54 & 2.60 & 1.04 & -- \\
\hline 27 & -- & 1.85 & 2.83 & 3.14 & 4.23 & 4.30 & 4.04 & 1.95 & 3.18 & 2.00 & 1.14 & -- \\
\hline 28 & -- & 1.44 & 2.47 & 2.96 & 4.31 & 3.68 & 2.49 & 2.33 & 3.25 & 2.07 & 1.32 & -- \\
\hline 29 & -- & -- & 2.35 & 3.04 & 4.10 & 3.49 & 4.75 & 2.27 & 3.56 & 1.88 & 1.43 & -- \\
\hline 30 & -- & -- & 2.49 & 2.59 & 3.77 & 3.25 & 4.65 & 1.95 & 3.26 & 1.69 & 1.48 & -- \\
\hline 31 & -- & -- & 2.40 & -- & 4.29 & -- & 4.77 & 2.36 & -- & 2.04 & -- & -- \\
\hline
\end{tabular}


Appendix 4. Water-quality and isotope data in samples collected from site $\mathrm{LC}_{\mathrm{sw}}$ (U.S. Geological Survey streamflow-gaging station 08180942 Laurel Canyon Creek near Helotes, Texas), Government Canyon State Natural Area, Bexar County, Tex.

$\left[\mathrm{ft}^{3} / \mathrm{s}\right.$, cubic feet per second; $\mu \mathrm{S} / \mathrm{cm}$, microsiemens per centimeter at 25 degrees Celsius; $\mathrm{mg} / \mathrm{L}$, milligrams per liter; per mill, parts per thousand; $\mathrm{CaCO}_{3}$, calcium carbonate; --, not calculated because streamflow exceeded weir rating; $\mathrm{N}$, Nitrogen; NH4, ammonium; P, phosphorus; $\delta \mathrm{D}$, delta deuterium; $\delta^{18} \mathrm{O}$, delta oxygen-18; <, less than; E, estimated]

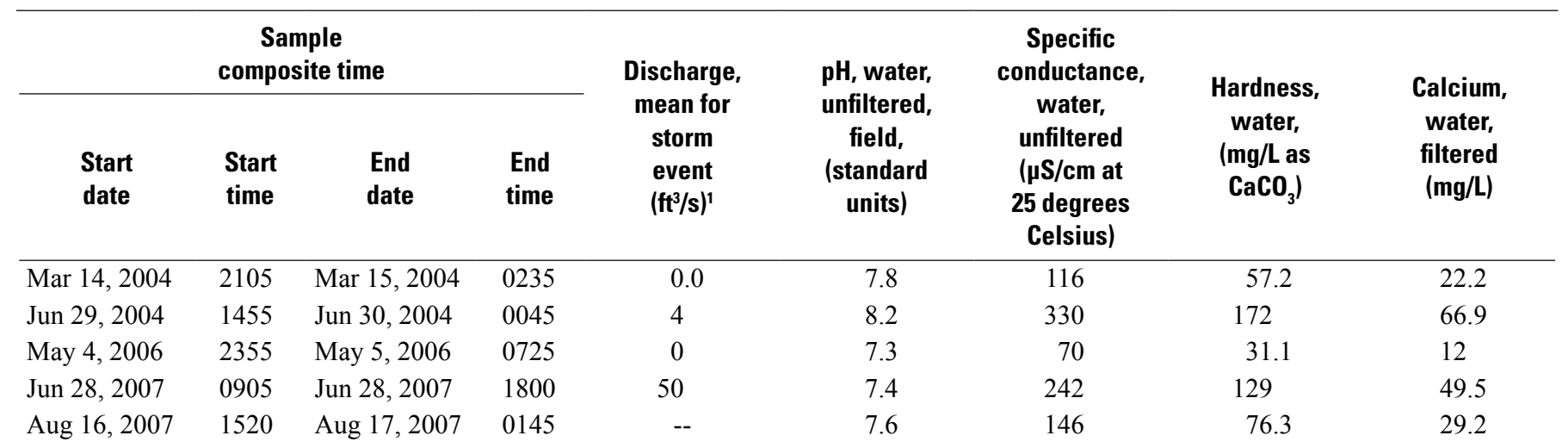

\begin{tabular}{|c|c|c|c|c|c|c|c|c|}
\hline \multicolumn{4}{|c|}{$\begin{array}{c}\text { Sample } \\
\text { composite time }\end{array}$} & $\begin{array}{c}\text { Magnesium, } \\
\text { water, } \\
\text { filtered } \\
\text { (mg/L) }\end{array}$ & $\begin{array}{l}\text { Potassium, } \\
\text { water, } \\
\text { filtered } \\
\text { (mg/L) }\end{array}$ & $\begin{array}{c}\text { Sodium } \\
\text { adsorption } \\
\text { ratio, } \\
\text { water } \\
\text { (number) }\end{array}$ & $\begin{array}{c}\text { Sodium } \\
\text { fraction of } \\
\text { cations, water } \\
\text { (percent in } \\
\text { equivalents of } \\
\text { major cations) }\end{array}$ & $\begin{array}{c}\text { Sodium, } \\
\text { water, } \\
\text { filtered } \\
(\mathrm{mg} / \mathrm{L})\end{array}$ \\
\hline Mar 14, 2004 & 2105 & Mar 15, 2004 & 0235 & 0.433 & 0.81 & 0.06 & 4 & 1.08 \\
\hline May 4, 2006 & 2355 & May 5, 2006 & 0725 & .281 & .92 & .07 & 6 & .87 \\
\hline Jun 28, 2007 & 0905 & Jun 28, 2007 & 1800 & 1.28 & 1.31 & .08 & 3 & 2.07 \\
\hline Aug 16, 2007 & 1520 & Aug 17, 2007 & 0145 & .845 & .90 & .05 & 3 & 1.01 \\
\hline
\end{tabular}

\begin{tabular}{|c|c|c|c|c|c|c|c|c|}
\hline \multicolumn{4}{|c|}{$\begin{array}{c}\text { Sample } \\
\text { composite time }\end{array}$} & \multirow{2}{*}{$\begin{array}{c}\text { Chloride, } \\
\text { water, } \\
\text { filtered } \\
\text { (mg/L) }\end{array}$} & \multirow{2}{*}{$\begin{array}{c}\text { Fluoride, } \\
\text { water, } \\
\text { filtered } \\
\text { (mg/L) }\end{array}$} & \multirow{2}{*}{$\begin{array}{c}\text { Total } \\
\text { hydrogen } \\
\text { ion } \\
(\mathrm{mg} / \mathrm{L})\end{array}$} & \multirow{2}{*}{$\begin{array}{c}\text { Silica, } \\
\text { water, } \\
\text { filtered } \\
\text { (mg/L) }\end{array}$} & \multirow{2}{*}{$\begin{array}{c}\text { Sulfate, } \\
\text { water, } \\
\text { filtered } \\
\text { (mg/L) }\end{array}$} \\
\hline $\begin{array}{l}\text { Start } \\
\text { date }\end{array}$ & $\begin{array}{l}\text { Start } \\
\text { time }\end{array}$ & $\begin{array}{l}\text { End } \\
\text { date }\end{array}$ & $\begin{array}{l}\text { End } \\
\text { time }\end{array}$ & & & & & \\
\hline Mar 14, 2004 & 2105 & Mar 15, 2004 & 0235 & 2.25 & $<0.17$ & 0.00002 & 1.91 & 2.35 \\
\hline Jun 29, 2004 & 1455 & Jun 30, 2004 & 0045 & 3.20 & $<.17$ & .00001 & 8.7 & 3.32 \\
\hline May 4, 2006 & 2355 & May 5, 2006 & 0725 & 1.79 & $<.10$ & .00005 & 1.1 & 1.65 \\
\hline Aug 16, 2007 & 1520 & Aug 17, 2007 & 0145 & .74 & $<.10$ & .00003 & 5.4 & 1.53 \\
\hline
\end{tabular}

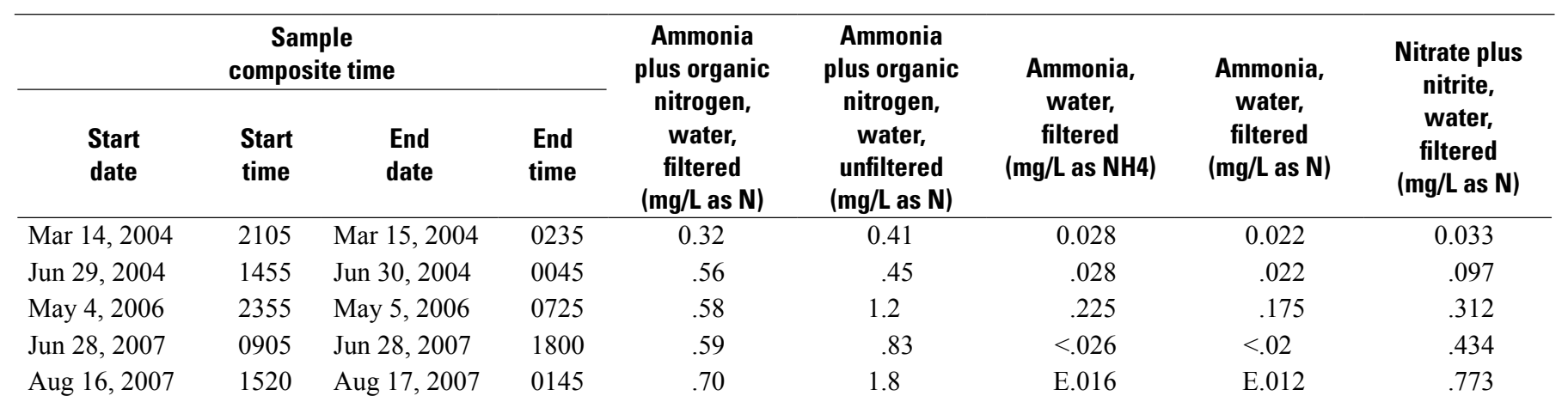


Appendix 4. Water-quality and isotope data in samples collected from site $\mathrm{LC}_{\mathrm{SW}}$ (U.S. Geological Survey streamflow-gaging station 08180942 Laurel Canyon Creek near Helotes, Texas), Government Canyon State Natural Area, Bexar County, Tex.-Continued

$\left[\mathrm{ft}^{3} / \mathrm{s}\right.$, cubic feet per second; $\mu \mathrm{S} / \mathrm{cm}$, microsiemens per centimeter at 25 degrees Celsius; $\mathrm{mg} / \mathrm{L}$, milligrams per liter; per mill, parts per thousand; $\mathrm{CaCO}_{3}$, calcium carbonate; --, not calculated because streamflow exceeded weir rating; $\mathrm{N}$, Nitrogen; NH4, ammonium; P, phosphorus; $\delta \mathrm{D}$, delta deuterium; $\delta^{18} \mathrm{O}$, delta oxygen-18; <, less than; E, estimated]

\begin{tabular}{|c|c|c|c|c|c|c|c|c|}
\hline \multicolumn{4}{|c|}{$\begin{array}{c}\text { Sample } \\
\text { composite time }\end{array}$} & \multirow{2}{*}{$\begin{array}{c}\text { Nitrate, } \\
\text { water, } \\
\text { filtered } \\
\text { (mg/L) }\end{array}$} & \multirow{2}{*}{$\begin{array}{c}\text { Nitrate, } \\
\text { water, } \\
\text { filtered } \\
\text { (mg/L as N) }\end{array}$} & \multirow{2}{*}{$\begin{array}{c}\text { Nitrite, } \\
\text { water, } \\
\text { filtered } \\
\text { (mg/L) }\end{array}$} & \multirow{2}{*}{$\begin{array}{c}\text { Nitrite, } \\
\text { water, } \\
\text { filtered } \\
\text { (mg/L as N) }\end{array}$} & \multirow{2}{*}{$\begin{array}{c}\text { Organic } \\
\text { nitrogen, } \\
\text { water, } \\
\text { filtered } \\
\text { (mg/L) }\end{array}$} \\
\hline $\begin{array}{l}\text { Start } \\
\text { date }\end{array}$ & $\begin{array}{l}\text { Start } \\
\text { time }\end{array}$ & $\begin{array}{l}\text { End } \\
\text { date }\end{array}$ & $\begin{array}{l}\text { End } \\
\text { time }\end{array}$ & & & & & \\
\hline Mar 14, 2004 & 2105 & Mar 15, 2004 & 0235 & E0.142 & E0.032 & E0.003 & E0.001 & 0.30 \\
\hline Jun 29, 2004 & 1455 & Jun 30, 2004 & 0045 & E.425 & E.096 & E.003 & E.001 & .53 \\
\hline Aug 16, 2007 & 1520 & Aug 17, 2007 & 0145 & 3.37 & .762 & .038 & .011 & E.69 \\
\hline
\end{tabular}

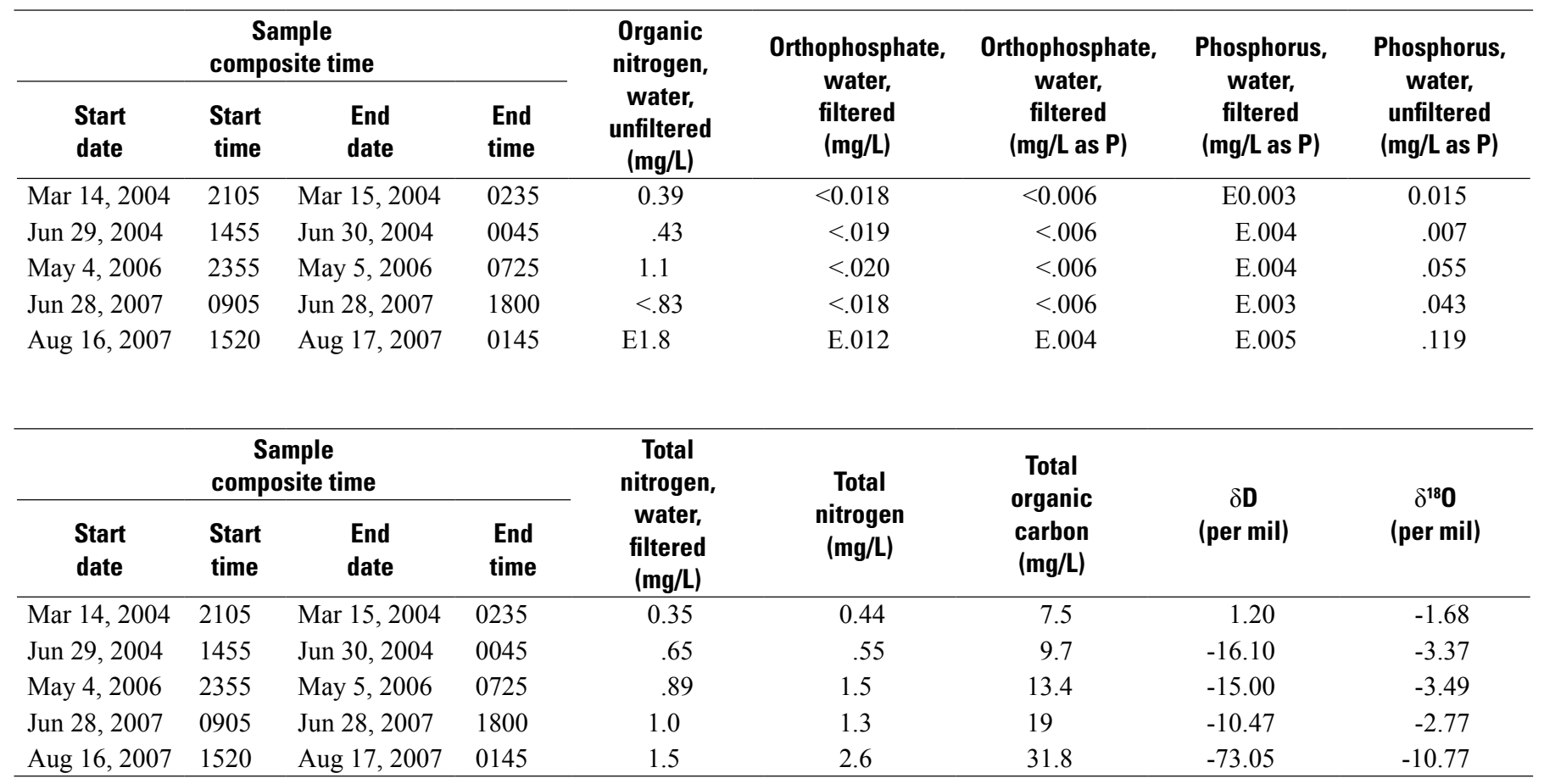

${ }^{1}$ For low flow storm events where mean event discharge was less than $0.5 \mathrm{ft}^{3} / \mathrm{s}$, mean event discharge was reported as $0.0 \mathrm{ft}^{3} / \mathrm{s}$.

Publishing support provided by

Lafayette Publishing Service Center

Information regarding water resources in Texas is available at

http://tx.usgs.gov/ 
